\title{
Renewable Energy Opportunities at Dugway Proving Ground, Utah
}
AC Orrell JA Horner
WJ Gorrissen
AR Kora JL Williamson
RJ Nesse, Project Manager
BJ Russo MR Weimar
DR Dixon, Program Manager

May 2010

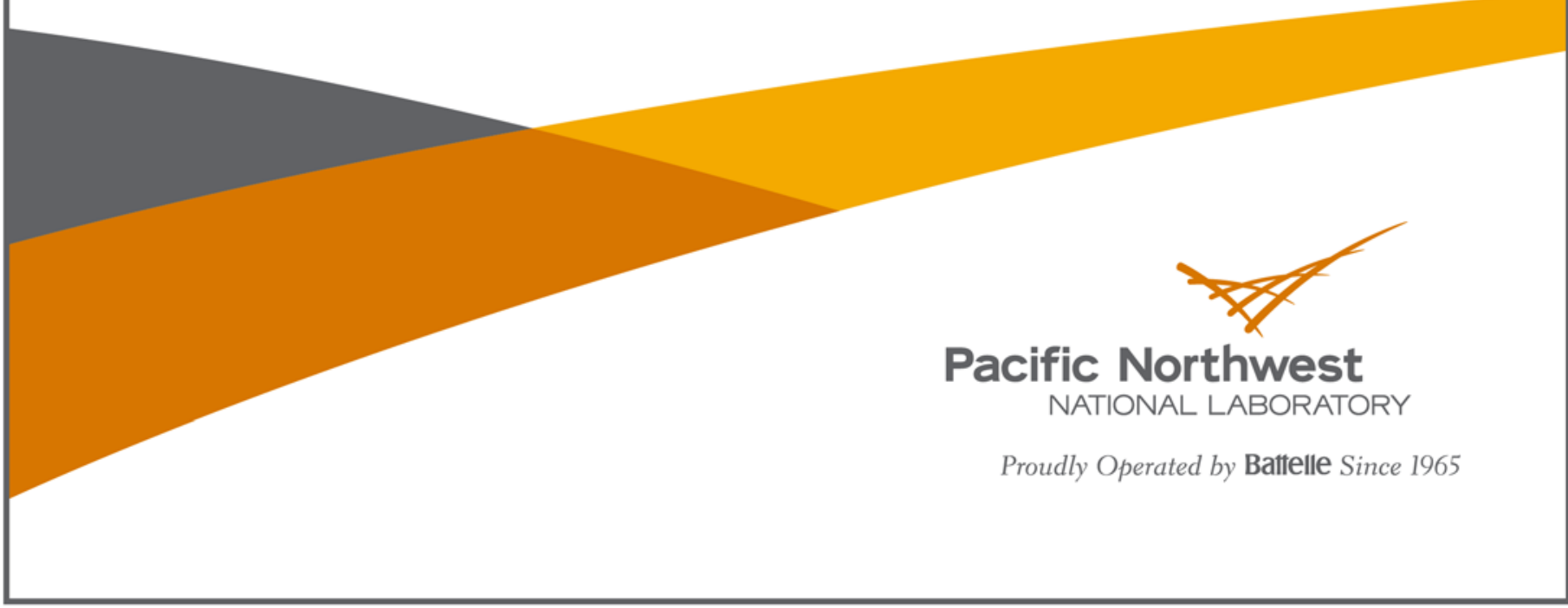




\title{
DISCLAIMER
}

This report was prepared as an account of work sponsored by an agency of the United States Government. Neither the United States Government nor any agency thereof, nor Battelle Memorial Institute, nor any of their employees, makes any warranty, express or implied, or assumes any legal liability or responsibility for the accuracy, completeness, or usefulness of any information, apparatus, product, or process disclosed, or represents that its use would not infringe privately owned rights. Reference herein to any specific commercial product, process, or service by trade name, trademark, manufacturer, or otherwise does not necessarily constitute or imply its endorsement, recommendation, or favoring by the United States Government or any agency thereof, or Battelle Memorial Institute. The views and opinions of authors expressed herein do not necessarily state or reflect those of the United States Government or any agency thereof.

\author{
PACIFIC NORTHWEST NATIONAL LABORATORY \\ operated by \\ BATTELLE \\ for the \\ UNITED STATES DEPARTMENT OF ENERGY
}

under Contract DE-AC05-76RL01830

Printed in the United States of America
Available to DOE and DOE contractors from the Office of Scientific and Technical Information, P.O. Box 62, Oak Ridge, TN 37831-0062; ph: (865) 576-8401 fax: (865) 576-5728
email: reports@adonis.osti.gov

\footnotetext{
Available to the public from the National Technical Information Service, U.S. Department of Commerce, 5285 Port Royal Rd., Springfield, VA 22161 ph: (800) 553-6847 fax: (703) 605-6900 email: orders@ntis.fedworld.gov online ordering: http://www.ntis.gov/ordering.htm
}

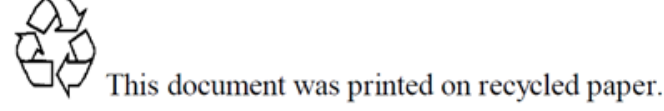

$(9 / 2003)$ 
PNNL - 19436

\title{
Renewable Energy Opportunities at Dugway Proving Ground, Utah
}

\author{
AC Orrell JA Horner WJ Gorrissen \\ AR Kora JL Williamson RJ Nesse, Program Manager \\ BJ Russo MR Weimar DR Dixon, Project Manager
}

May 2010

Prepared for the U.S. Army Installation Management Command Headquarters under Contract DE-AC05-76RL01830 Related Services

Pacific Northwest National Laboratory Richland, Washington 99352 



\section{Executive Summary}

This document provides an overview of renewable resource potential at Dugway Proving Ground, based primarily upon analysis of secondary data sources supplemented with limited on-site evaluations. This effort focuses on grid-connected generation of electricity from renewable energy sources and ground source heat pumps (GSHPs). The effort was funded by the U.S. Army Installation Management Command (IMCOM) as follow-on to the 2005 Department of Defense (DoD) Renewables Assessment. The site visit to Dugway Proving Ground took place on October 14, 2009.

At this time, a few renewable technologies show economic potential at Dugway Proving Ground. Project feasibility is based on installation-specific energy costs and projections based on accepted life-cycle cost methods (Appendix A). Dugway Proving Ground is fortunate to have relatively lowcost electricity compared to other DoD facilities. However, this low cost also presents a challenge to developing cost-effective renewable energy projects. On the other hand, Dugway Proving Ground is at the end of its electrical feeder, and electrical outages are not uncommon. Therefore, some of these renewable energy opportunities may be attractive as backup power or to enhance the site's energy security.

The most feasible renewable opportunities are GSHPs and geothermal power. Renewable energy development at the site will require further investigation into the relationships among Dugway Proving Ground and the local utility, Rocky Mountain Power, because of complicated contractual and regulatory issues. At this time, Utah has a renewable portfolio standard that is more accurately described as a renewable portfolio goal, which requires utilities to source $20 \%$ of their energy from renewable sources (when cost-effective) by 2025. Also, there are no intermediary goals between the present and 2025. Consequently, the renewable energy credit (REC) market in Utah is relatively insignificant at this time and did not factor into the economic analyses contained in this report.

\section{Ground Source Heat Pumps}

Ground source heat pumps were generally found to be appropriate for Dugway Proving Ground. These findings are predominantly driven by the low cost of electricity at Dugway Proving Ground coupled with the relatively high cost of the only other available fossil fuel types, propane and fuel oil. Open-loop systems were found to be the most cost-effective, and should be considered to potentially increase the number of economic projects and associated savings from the renewable resource. The approval process for installing an open-loop GSHP should be investigated in detail. Horizontal closed-loop systems should be used wherever land will likely not be disturbed. Detailed GSHP results are provided in Appendix D.

\section{Geothermal Power}

The resource analysis for Dugway Proving Ground found moderate potential for utility-grade geothermal electricity production, although there is no potential for a cost-effective project at current market conditions because of Dugway Proving Ground's relatively low cost of electricity. The biggest factor in the capital cost is the number of expensive wells required to produce adequate hot water and steam resources at sufficient flow rates. The resource estimations need to be confirmed with actual well data and further geological studies. Further study is required to determine the actual drilling costs and depth required to reach a temperature of $150^{\circ} \mathrm{C}\left(302^{\circ} \mathrm{F}\right)$. Detailed results are provided in Appendix C. 


\section{Solar Power}

Solar photovoltaics (PV) were not found to be cost-effective without additional incentives. The most economic solar project potential was for axis-tracking PV arrays as well as lower cost roof membrane arrays. A number of appropriate buildings for membrane arrays were identified, although a more thorough study should be conducted to explicitly identify candidate buildings. In short, although Dugway Proving Ground has a moderately high solar resource, the access to very low-cost power hampers the economic feasibility of these systems. Details are given in Appendix E.

Other renewable technologies did not prove to be cost-effective or worthwhile to develop with current conditions and assumptions. The waste-to-energy projects, including landfill gas, evaluated at Dugway Proving Ground represent marginal potential given Dugway Proving Ground’s low average power demand (Appendix B). Lastly, the wind resource was not sufficient to justify largeor small-scale wind projects (Appendix F). Table 1 summarizes these findings below.

Increasing use of renewable energy makes sense for the Army. The goal of this report is to help Army personnel make sense of renewable energy potential and opportunities at Dugway Proving Ground.

Table 1: Summary of Promising Renewable Energy Projects at Dugway Proving Ground

\begin{tabular}{|c|c|c|c|c|c|c|c|c|}
\hline & \begin{tabular}{|c|} 
Renewable \\
Resource and \\
Technology \\
\end{tabular} & $\begin{array}{l}\text { Resource } \\
\text { Estimate }\end{array}$ & $\mid \begin{array}{c}\text { Earliest } \\
\text { Output }\end{array}$ & Figures of Merit & $\begin{array}{c}\text { Financing } \\
\text { Mechanisms } \\
\text { Evaluated } \\
\end{array}$ & Location--Requirements & Key Assumptions & $\begin{array}{l}\text { Next Steps } \\
\text { Comments }\end{array}$ \\
\hline 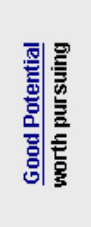 & $\begin{array}{l}\text { Ground } \\
\text { Source Heat } \\
\text { Pump } \\
\text { (Thermal } \\
\text { Energy) }\end{array}$ & TED & 2011 & $\begin{array}{c}1.0-20 \mathrm{SIR}, 0.8-14 \\
\text { year payback }\end{array}$ & $\begin{array}{l}\text { ECIP } \\
\text { IPP } \\
\text { UESC }\end{array}$ & $\begin{array}{c}\text { Adequate heat sources } \\
\text { and sinks proximate to } \\
\text { GSHPs }\end{array}$ & $\begin{array}{l}\text { There are buildings } \\
\text { that require heating } \\
\text { and potentially cooling. } \\
\text { Suitable land area and } \\
\text { soil characteristics for } \\
\text { closed loop GSHPs. }\end{array}$ & $\begin{array}{l}\text { Site surveys to } \\
\text { determine whether } \\
\text { suitable heat sinks } \\
\text { and sources exist, } \\
\text { and to provide the } \\
\text { detailed soil } \\
\text { characterization to } \\
\text { base system design. }\end{array}$ \\
\hline \multirow{2}{*}{ 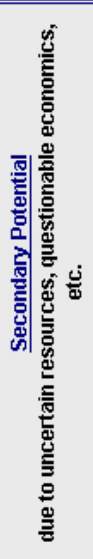 } & $\begin{array}{l}\text { Utility-Grade } \\
\text { Solar Electric } \\
\text { Power Plant }\end{array}$ & $\begin{array}{c}100 \mathrm{KW}-1 \\
\mathrm{MW} \text { (or } \\
\text { more if } \\
\text { space is } \\
\text { available) }\end{array}$ & 2012 & $\begin{array}{c}10 \% \text { IPP scenarios }= \\
32-36 \% \text { Wh w/ } 17- \\
24 \% \text { capacity factor } \\
\\
\text { ECIP scenarios w/ } \\
4.68 \% \text { Wh = negative } \\
\text { IRR, } 0.0-0.1 \text { SIR, } 100 \\
\text { + year payback }\end{array}$ & $\begin{array}{l}\text { ECIP } \\
\text { IPP }\end{array}$ & $\begin{array}{l}\text { Small scale: rooftops } \\
\text { (especially when } \\
\text { replacing rooftops), open } \\
\text { ground areas with } \\
\text { minimal shading or } \\
\text { concerns over } \\
\text { vandalism. } \\
\text { Large scale: near high } \\
\text { voltage transmission } \\
\text { lines, adequate open } \\
\text { space for array and } \\
\text { inverter system } \\
\end{array}$ & $\begin{array}{l}\text { Proposed project will } \\
\text { not interfere with any } \\
\text { on-site systems. }\end{array}$ & $\begin{array}{l}\text { PV via an ECIP is not } \\
\text { viable. Wait until a } \\
\text { renewable portfolio } \\
\text { standard (RPS) is } \\
\text { enacted, electric } \\
\text { rates increase, or PV } \\
\text { capital costs } \\
\text { decrease }\end{array}$ \\
\hline & $\begin{array}{l}\text { High } \\
\text { Temperature } \\
\text { Geothermal } \\
\text { Generation }\end{array}$ & $5 \mathrm{MW}$ & 2013 & $\begin{array}{c}10 \% \text { IPP scenarios }= \\
11.4 \% \text { ikWh w/ } 96 \% \\
\text { capacity factor } \\
\text { ECIP scenarios w/ } \\
4.6 \% \text { Wh = negative } \\
\text { IRR, } 0.2 \mathrm{SIR}, 48 \text { year } \\
\text { payback }\end{array}$ & $\begin{array}{l}\text { ECIP } \\
\text { IPP }\end{array}$ & $\begin{array}{l}\text { Temperatures }>100^{\circ} \mathrm{C} \text { at } \\
\text { depths less than } 3 \mathrm{~km} \text {, hot } \\
\text { water or steam flow rates }> \\
1000 \text { gpm, heat flow rates } \\
=80 \mathrm{~mW}^{2}\end{array}$ & $\begin{array}{l}\text { High temperatures, fluid } \\
\text { flow, and heat flows are } \\
\text { available at economic } \\
\text { depths. }\end{array}$ & $\begin{array}{l}\text { Geothermal resource } \\
\text { may be available, but } \\
\text { verification } \\
\text { equipment is too } \\
\text { costly to risk not } \\
\text { finding a valuable } \\
\text { resource at current } \\
\text { market conditions }\end{array}$ \\
\hline
\end{tabular}

SIR = savings to investment ratio,

ECIP = energy conservation and investment program,

IPP = independent power producer,

UESC = utility energy service contract, 


\section{Table of Contents}

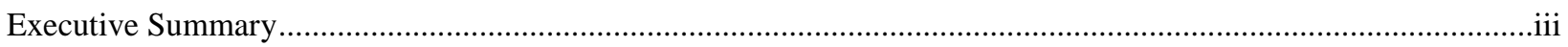

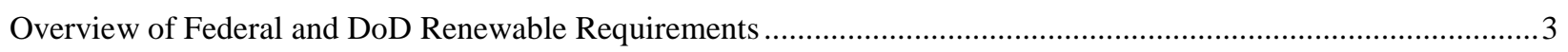

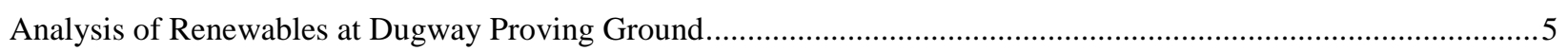

Approach for Identifying, Analyzing, and Implementing Renewable Energy Projects ..............................5

Importance of Financing Mechanisms for Project Feasibility .......................................................... 6

The Political and Economic Environment for Renewables at Dugway Proving Ground .............................

Dugway Proving Ground Energy Characterization............................................................ 7

State Incentives for Renewable Project Development .........................................................8

Federal Incentives for Renewable Project Development ........................................................9

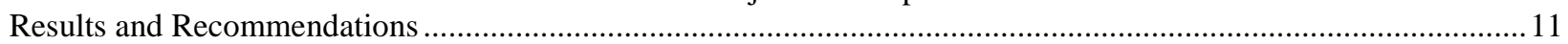

Ground Source Heat Pump Findings and Recommendations........................................................... 12

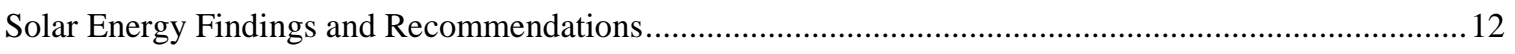

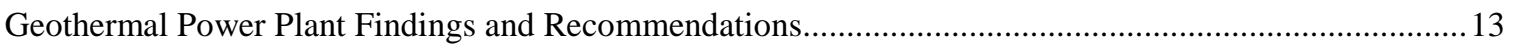

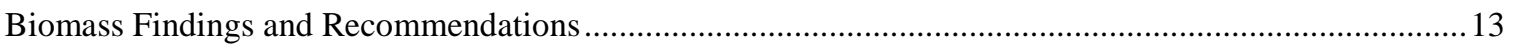

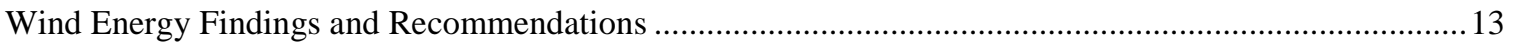

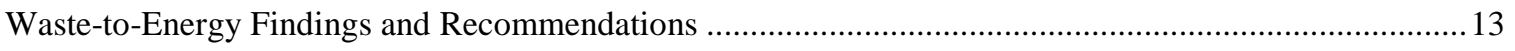

Analysis of Renewables at Dugway Proving Ground Bibliography ................................................... 14

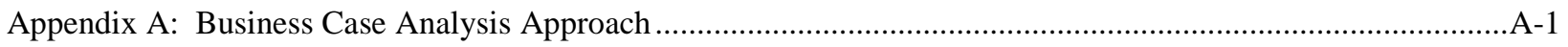

Overall Basis for Project Economic Feasibility..........................................................................

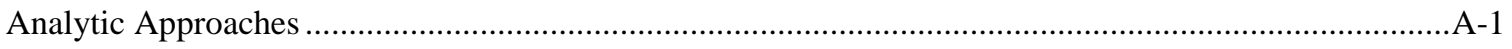

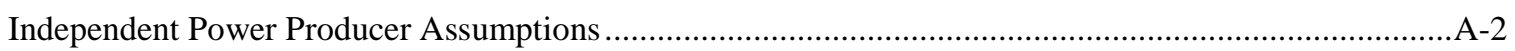

Federal Incentives for Renewable Energy...................................................................A-2

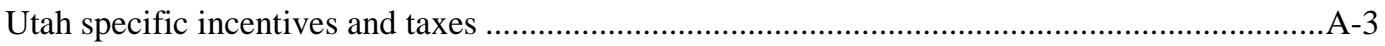

Other Independent Power Producer Assumptions...............................................................A-5

Energy Conservation Investment Projects....................................................................................

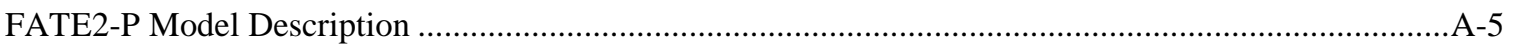

Private Ownership Rate of Return Methodology …............................................................6

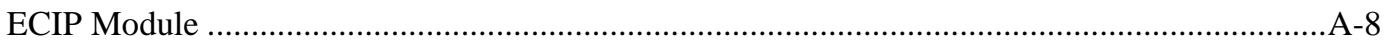

The Federal Energy Decision System (FEDS) Model.....................................................................

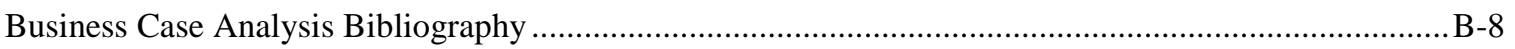

Appendix B: Analysis of Biomass and Waste-to-Energy Opportunities .........................................................

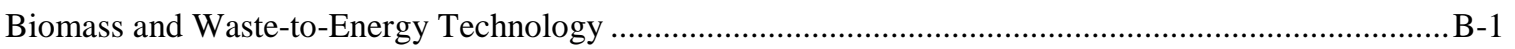

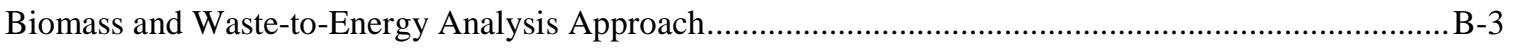

Biomass and Waste Resource Characterization ............................................................................ B-4

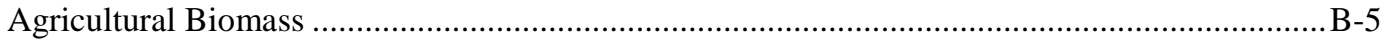

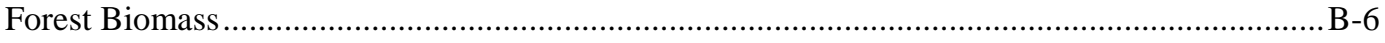

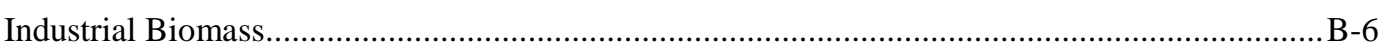

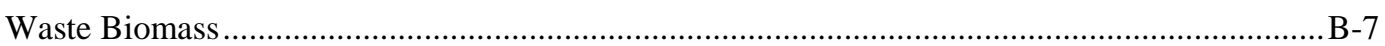

Biomass and Waste-to-Energy: Economic and Other Analysis Parameters........................................... B-10 


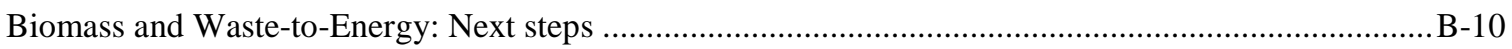

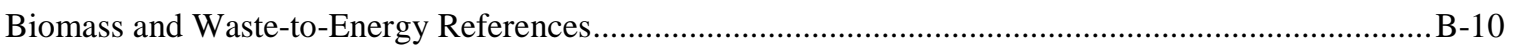

Appendix C: Analysis of Geothermal Power Plant Opportunities............................................................................

Geothermal Energy Analysis Approach .................................................................................................

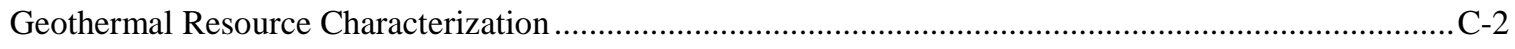

Geothermal Power Plants: Economic and Other Analysis Parameters........................................................

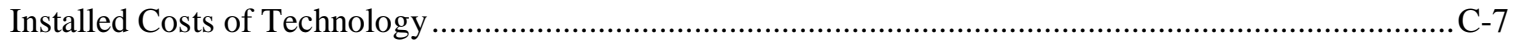

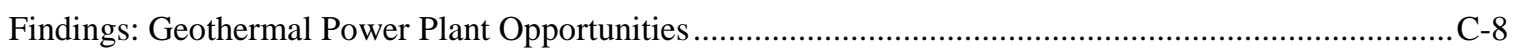

Geothermal Power Plants: Next Steps............................................................................................

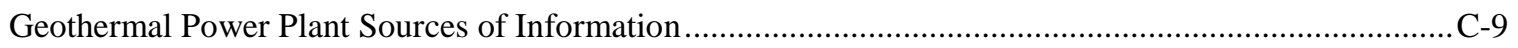

Appendix D: Analysis of Ground Source Heat Pump Opportunities ....................................................................

Ground Source Heat Pump Analysis Approach ..................................................................................

Ground Source Heat Pump Resource Characterization..........................................................................

Ground Source Heat Pumps: Economic and Other Analysis Parameters...............................................D-5

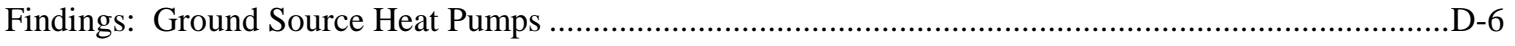

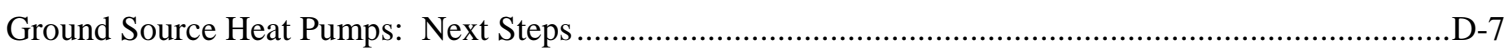

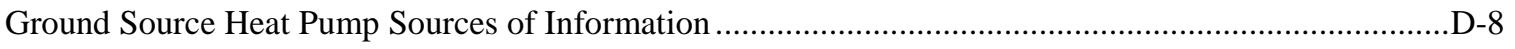

Appendix E: Analysis of Solar Opportunities .................................................................................................... E-1

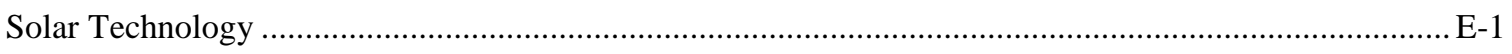

Solar Electric...................................................................................................................... E-1

Solar Thermal \& Daylighting................................................................................................. E-3

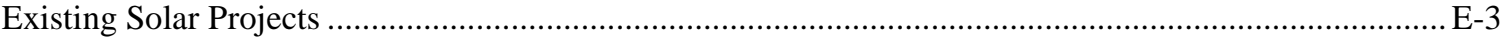

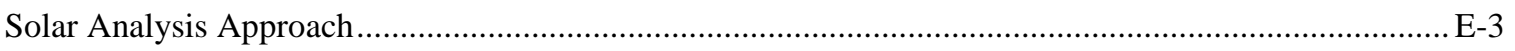

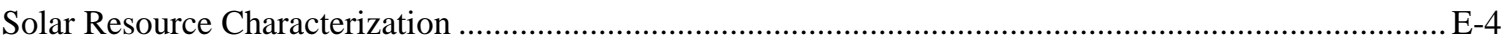

Siting Considerations for Solar Technologies .................................................................................... E-5

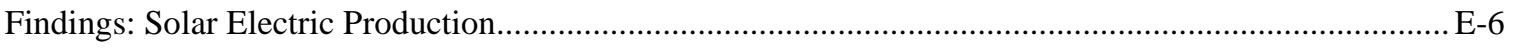

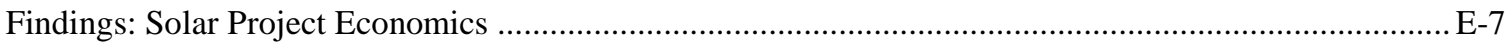

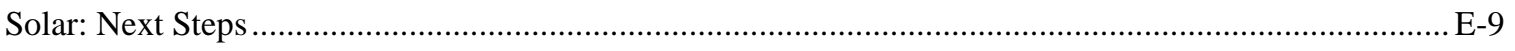

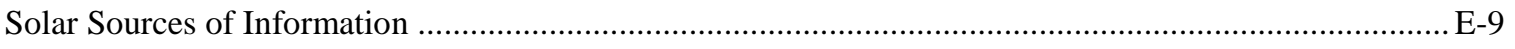

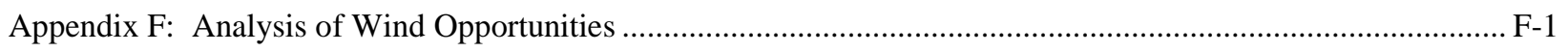

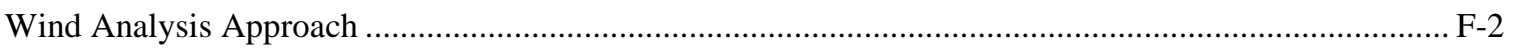

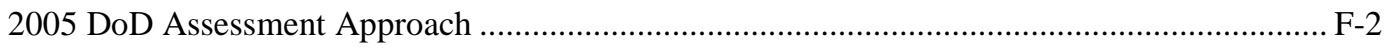

Updated Wind Analysis Approach................................................................................. F-2

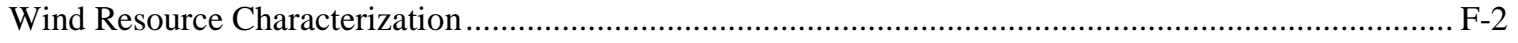

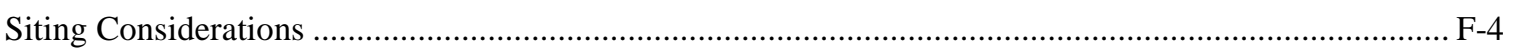

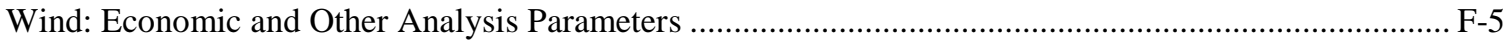

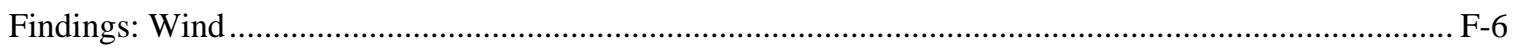

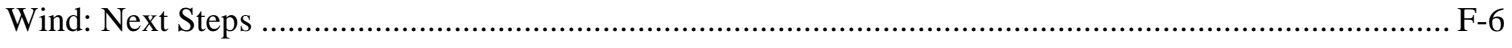

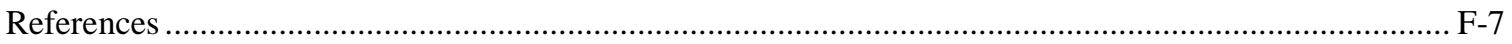




\section{Figures}

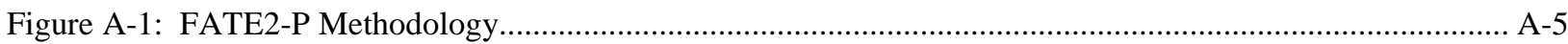

Figure C-1: Geothermal Resources and Uses in Utah (Utah Geothermal Working Group (UGWG) 2005)............C-3

Figure C-2: Geothermal Temperatures from the DOD Geothermal Assessment (ITSI 2003)...................................-6

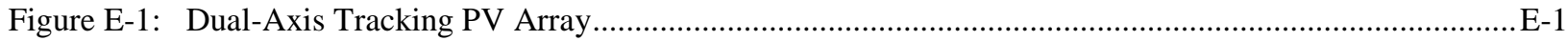

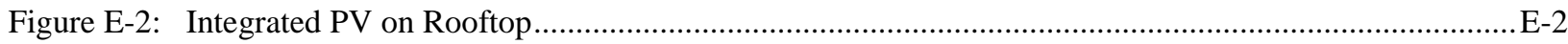

Figure E-3: Fort Huachuca Stirling Engine Solar Dish ....................................................................................... E-2

Figure E-4: Solar Insolation Levels, 3Tier FirstLook Solar Resource Map ............................................................ E-4

Figure E-5: Average Daily Insolation at Dugway Proving Ground...................................................................... E-5

Figure F-1: Highest Wind Speed on Dugway Proving Ground ................................................................................ F-3 


\section{Tables}

Table 1: Summary of Promising Renewable Energy Projects at Dugway Proving Ground .......................................iv

Table 2: Legislated Renewable Energy Targets for DoD .....................................................................................

Table 3: Summary of Dugway Proving Ground Renewable Energy Opportunities ..................................................11

Table 4: Economic Results for Solar PV Technologies at Dugway Proving Ground................................................12

Table A-1: MACRS Depreciation Rates for Renewable Energy Projects .............................................................. A-3

Table A-2: Discount Rate Assumptions in the ECIP Model ................................................................................... A-5

Table B-1: Crops and Biomass Production near Dugway Proving Ground.............................................................

Table B-2: Waste near Dugway Proving Ground .................................................................................................

Table C-1: Performance, Cost, and Economic Characteristics ....................................................................................

Table D-1: Building Groups Analyzed in FEDS for GSHPs............................................................................. D-3

Table D-2: Buildings Analyzed in FEDS for GSHPs .................................................................................. D-4

Table D-3: Simple Payback Period for Building Groups Analyzed in FEDS for GSHPs ....................................... D-7

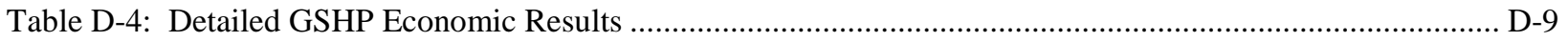

Table E-1: Monthly Averaged Insolation Incident on an Equator-Pointed Tilted Surface at Dugway Proving Ground

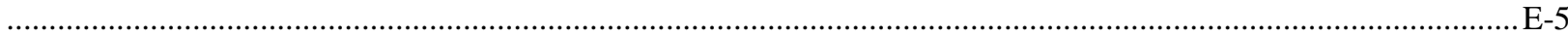

Table E-2: Roof-Integrated Membrane PV Analysis at Dugway Proving Ground................................................... E-7

Table E-3: Solar Electric Production by System Type at Dugway Proving Ground ..................................................-7

Table E-4: Economic Results for Solar Technologies at Dugway Proving Ground .................................................. E-9

Table F-1: Classes of Wind Power Density at 50 Meters .......................................................................................... F-3

Table F-2: Summary of Wind Resource Data.................................................................................................

Table F-3: Performance, Cost, and Economic Characteristics ............................................................................ F-6

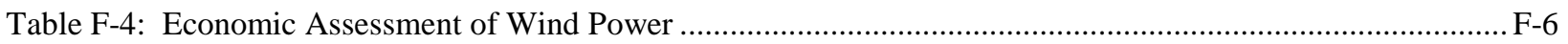




\section{Introduction}

Pacific Northwest National Laboratory (PNNL) has been directed by the U.S. Army Installation Management Command (IMCOM) to conduct detailed analyses of the potential for electricity generation at selected U.S. Army installations. The goal of the analyses is to identify economically feasible opportunities for electricity generation from renewable resources-generation that is significant enough to warrant connection to the grid and/or to contribute in a meaningful way to the aggressive renewable energy goals of the Army and the Department of Defense (DoD).

In 2005, PNNL completed a study to identify utility-scale electricity generation opportunities at DoD installations. That study focused on solar, wind, and geothermal. A limited number of attractive large-scale commercial opportunities were identified and their implementation is now being pursued. The study also identified a number of potential smaller opportunities that needed to be investigated further before project implementation decisions could be made.

This analysis of opportunities at Dugway Proving Ground is one of a suite of analyses being conducted at Army installations as follow-on to the 2005 study. Its goal is to revisit potential renewable opportunities, updating the analysis for changes in economics, incentives, knowledge about the available renewable resource, and other factors. In addition, IMCOM has directed PNNL to evaluate the potential for biomass, waste-to-energy, and retrofitting heating and cooling systems in existing buildings with ground source heat pumps (GSHPs). Retrofitting with GSHPs is obviously not an electricity generation opportunity, but it is an opportunity for energy savings and replacement of fossil fuels across DoD. As part of the analysis, IMCOM has directed PNNL to lay out the steps necessary to implement the project opportunities that are identified.

The overall findings of this analysis are summarized in the main body of the report. The business case approach that underlies the analysis of each renewable technology is documented in Appendix A. Appendix B describes the analysis conducted on biomass and waste-to-energy technologies. Appendix C describes the geothermal power analysis; Appendix D, the GSHP analysis; Appendix E, the solar analysis; and Appendix F, the wind energy analysis. 
Renewable Energy Opportunities at Dugway Proving Ground, UT

Pacific Northwest National Laboratory, May 2010 


\section{Overview of Federal and DoD Renewable Requirements}

The Army needs to satisfy multiple goals and constraints while securing its energy suppliesfocusing upon procurement of the lowest-cost energy that meets high reliability standards and minimum vulnerability to interruption from natural or intentional causes. Overlaid on this challenge is the need to comply with a series of somewhat contradictory statutes and policies, as laid out in Table 2. These include:

Energy Policy Act of 2005 (EPAct) Section 203. This law mandates the minimum contribution of renewable electricity to an installation's total electricity consumption. The target fractions are 3\% for FY 2007 through FY 2009, 5\% through FY 2012, and not less than 7.5\% beginning in FY 2013.

Executive Order (EO) 13423. The Executive Order reiterates the EPAct goals; however, it uses a different basis than EPAct for measuring and crediting progress. For example, renewable thermal energy counts toward the renewable goal.

National Defense Authorization Act (NDAA). The NDAA codifies DoD's voluntary goal of $25 \%$ by 2025 , but does not include any interim targets. Renewable thermal energy counts toward the renewable goal.

Energy Independence and Security Act of 2007 (EISA) Section 433. EISA established two additional renewable goals for new buildings and retrofits. One requires $30 \%$ of domestic hot water to be supplied from solar energy, and the other requires all fossil fuels used in buildings to be displaced by 2030. This is not a generation goal like the others, but is important to note.

Executive Order (EO) 13514. This order expands on the environmental goals of EO 13423 by focusing on reduction of greenhouse gas emissions. It requires Federal agencies to report greenhouse gas emissions and work with the Council on Environmental Quality (CEQ) to set reduction targets relative to a FY 2008 baseline. Implementing renewable energy technologies, which are typically less greenhouse gas intensive than traditional forms of energy production, is one strategy that sites could implement to meet the requirements outlined by this order. 
Table 2: Legislated Renewable Energy Targets for DoD

\begin{tabular}{|c|c|c|c|c|c|}
\hline & $\begin{array}{l}\text { EPAct } 2005 \\
\text { Section } 203\end{array}$ & $\begin{array}{c}\text { Executive Order } \\
13423\end{array}$ & $\begin{array}{c}\text { National } \\
\text { Defense } \\
\text { Authorization } \\
\text { Act }\end{array}$ & $\begin{array}{c}\text { Energy } \\
\text { Independence } \\
\text { and Security } \\
\text { Act }\end{array}$ & $\begin{array}{c}\text { Executive } \\
\text { Order (EO) } \\
13514\end{array}$ \\
\hline Target / Goal & $\begin{array}{l}\text { Increasing targets } \\
\text { reaching } 7.5 \% \text { of } \\
\text { electric energy from } \\
\text { renewables }\end{array}$ & $\begin{array}{c}\text { 7.5\% of electric } \\
\text { energy from } \\
\text { renewables; } 50 \% \\
\text { from new (post-1998) } \\
\text { sources } \\
\end{array}$ & $\begin{array}{l}\text { Equivalent of } \\
25 \% \text { of electric } \\
\text { energy from } \\
\text { renewables }\end{array}$ & $\begin{array}{l}30 \% \text { of hot } \\
\text { water demand } \\
\text { from solar }\end{array}$ & $\begin{array}{c}\text { Reduction of } \\
\text { greenhouse gas } \\
\text { emissions }\end{array}$ \\
\hline Target Dates & 2013 & 2013 & 2025 & $\begin{array}{c}\text { All new } \\
\text { construction / } \\
\text { major } \\
\text { renovations } \\
\end{array}$ & 2020 \\
\hline Mandatory? & Yes & Yes & No & Yes & Yes \\
\hline $\begin{array}{l}\text { Considers thermal } \\
\text { energy “renewable"? }\end{array}$ & No & Yes & Yes & N/A & N/A \\
\hline
\end{tabular}

This assessment is primarily for renewable energy provision and retrofit applications (e.g., ground source heat pumps or roof-integrated PV) in existing buildings. Accordingly, potential in new building construction is mentioned only in passing. The Department of Energy (DOE) is responsible for developing guidance for EPAct and EO 13423. DOE's guidelines for EO compliance, unlike EPAct, allow credit for renewable energy that reduces electricity use from thermal sources; however, it adds a requirement that at least $50 \%$ of renewable energy must come from "new" resources, which are those put into service after January 1, 1999.

Congress did not provide a definition of "renewable" in the NDAA language, and DOE is not responsible for establishing DoD or Army policies to achieve the goals in the NDAA. The current Army energy strategy and associated draft renewable policy takes an expansive view of renewables that encompasses thermal energy from renewable sources. As a result, the Army needs to proceed in a way that makes sense for the Army in a good faith effort to satisfy Congressional, Administration, and Pentagon mandates and directives. The expectation is that the Army will meet the stricter definitions of EPAct on its way to meeting the much higher renewable goals of the NDAA. 


\section{Analysis of Renewables at Dugway Proving Ground}

The goal of this analysis is to revisit the full suite of renewable alternatives at Dugway Proving Ground, updating the 2005 DoD analyses to reflect changes in economics, incentives, local knowledge about the renewable resources, and other factors. This study contrasts with the DoD assessment in that the latter focused on "utility-scale" renewable generating projects from wind, geothermal, and solar resources. The current study encompasses the full range of renewable energy options listed in EPAct, focused on any size project greater than 1 MW (except for buildingintegrated technologies, which are typically smaller). The most significant additions are assessments for biomass and waste-to-energy (WTE) resources and for the use of GSHPs.

The site visit to Dugway Proving Ground took place October 14, 2009 with Ron Nesse and Bryan Russo in attendance for PNNL. The principal points of contact for Dugway Proving Ground that attended the meeting included John Andersen (Director of Public Works, DPW) and Steven Robertson (Master Planner, DPW).

\section{Approach for Identifying, Analyzing, and Implementing Renewable Energy Projects}

Renewable energy resources are unlike conventional resources because the "fuel" is essentially free. However, harnessing this free resource requires substantial investment in resource exploration, characterization, and collection; project development; and ongoing maintenance and operation. A renewable resource is like purchasing a new car with a lifetime of fuel as part of the purchase agreement. First costs are much higher, but total cost may be lower over the long run.

Economic development of renewable energy depends upon:

- Access to a renewable resource

- Development resources

- Financing that is economically attractive and allowed by Federal and DoD regulations.

Each of these is critically important.

Naturally, a renewable resource has to be available and accessible to be developed. The best resources are those with the greatest potential for displacing conventional fuels or power supplies. Development cost, however, is the great equalizer, and a project based upon an excellent resource that is located many miles away may be inferior to a project based upon a lesser resource nearby. For example, an excellent wind resource far from an adequate transmission line may be less attractive than an inferior resource adjacent to a transmission line. Similarly, waste resources that could be used in a central plant may not be economic, even if they are "free", if the transportation, handling, and storage costs are greater than the cost of continued use of conventional heating fuels.

Development costs are relatively comparable for similar size projects. This is why the quality of the resource is so important - namely for the same investment, a project may produce better results with a high quality resource than a lower quality one. But, development costs also include access to transmission capacity for shipping power for uses on-site, or over commercial networks to the site or other retail customers. The latter is a critical difference because power shipped to other customers has to compete against the prevailing wholesale price for power from conventional resources. Typically, renewables are not competitive in these markets unless a buyer specifically demands 
renewable power. On the other hand, if the power can be used on-site to displace power purchased from the local utility, it competes against that customer's retail power price or utility rate. Because retail power prices include costs for transmission, distribution, and administrative costs, they are higher than wholesale power prices and make competing renewable projects more attractive economically.

It is important that economic analyses of renewable energy opportunities use realistic data on avoided energy costs, project costs, and available incentive funds, if any. A common analytic mistake is the use of average cost per $\mathrm{kWh}$ - the so-called "blended" rate. Using the blended rate will lead to inaccurate results when the renewable resource is intermittent (like wind and solar) because intermittent resources cannot be guaranteed to reduce peak demand. Even non-intermittent resources may not result in reduced peak demand because of periodic maintenance shutdowns and unscheduled outages. The economic analyses in this report use only the energy component of the power bill to evaluate intermittent resources, which is admittedly conservative. The blended rate is used for analysis of base-load resources.

In addition, the installation's utility may impose a standby or other fee in the face of a major on-site generation project that needs to be reflected in the project's cost calculation. The analyses conducted here make no assumptions regarding standby charges because those are typically assessed on a project-by-project basis.

The economic analyses in this report used two perspectives: Energy Conservation Investment Program (ECIP) funding and third-party financing. Use of appropriated funds via ECIP is the leastcost project finance option. However, incentives available to private owners of renewables can offset this advantage. As a result, these two evaluations effectively bracket reasonable project development costs and resulting power prices. Under the third-party arrangement, power is sold through a contract that is commonly called a power purchase agreement or PPA. This analysis assumed that an internal rate of return (IRR) of $10 \%$ is the minimum required to attract a third-party developer. The ECIP analyses assumed projects were not cost-effective if the savings-to-investment ratio (SIR) was less than 1.0.

\section{Importance of Financing Mechanisms for Project Feasibility}

Financing is a critical determinant of development costs because the high first costs are sensitive to financial factors such as incentive payments, tax breaks, and interest rates. Incentive payments and tax breaks reduce first costs, lowering both the overall project cost and interest costs. Because financing is so critical, project economics (payback rates, life-cycle costs, etc.) constitute the best initial screen for project potential. This screen needs to reflect various financing alternatives, which in turn helps energy managers decide on the best project development approach.

The 2005 DoD Renewables Assessment focused on wind, solar and geothermal power production under the assumption these were the lowest-cost and most available resources on DoD lands. The study was also focused on "utility-scale" projects on the premise that if a good renewable resource exists at a site, it should be developed to its maximum potential. This study also focuses on developing resources to their maximum potential, and does not typically analyze projects smaller than $1 \mathrm{MW}$. These large projects typically exceed any realistic expectation for appropriated funding, and so the assessments focused on commercial (third-party) development of projects. Besides funding limitations, there are other reasons that these large projects should be implemented by thirdparty investors - under current DoD philosophy, energy resource development, ownership, operation, 
and maintenance is not a core DoD mission and should be left to the private sector. In addition, private developers value renewable energy credits (RECs) more highly than the Army does. As a result, letting the developers retain the RECs will reduce the cost of energy to the installation if the developer is selling power from the project to the site.

\section{The Political and Economic Environment for Renewables at Dugway Proving Ground}

\section{Dugway Proving Ground Energy Characterization}

Dugway Proving Ground obtains its electricity from Rocky Mountain Power. Rocky Mountain Power provides electricity on a time of use basis with seasonal components plus demand charges based on peak demand. Summer rates occur during May through September with on-peak hours occurring during 1300 to 2100 hours, Monday through Friday. Winter peak hours occur 700 to 2300 hours, Monday through Friday. On-peak and off-peak summer rates were $\$ 0.034643 / \mathrm{kWh}$ and $\$ 0.02176 / \mathrm{kWh}$, respectively, as of June 2009. On-peak and off-peak winter rates are $\$ 0.026049 / \mathrm{kWh}$ and $\$ 0.02176 / \mathrm{kWh}$, respectively. Demand charges include a facility charge of $\$ 1.65 / \mathrm{kW}$, a summer demand charge of $\$ 10.40 / \mathrm{kW}$, and a winter demand charge of $\$ 7.05 / \mathrm{kW}$. Past bills have also included customer efficiency charges of approximately $\$ 0.02 / \mathrm{kWh}$. A $4 \%$ rate increase was included for 2010 based on communications with Rocky Mountain Power.

Rocky Mountain Power supplied about 39,153 MWh to Dugway Proving Ground, with the minimum peak power demand of 5.3 MW in October 2008 and the maximum of 6.9 MW in July. The largest average demand occurred in July at $5.1 \mathrm{MW}$, and the minimum in November at 3.9 MW.

It is important that economic analyses of renewable energy opportunities use realistic data on avoided energy costs. Intermittent resources, such as solar and wind, cannot reliably displace power and should not claim power savings. Therefore, solar and wind renewable energy resources depend on meeting the direct energy charge, while geothermal and waste-to-energy need to compare favorably against the average avoided cost including demand charges. We used a direct energy rate of $\$ 0.026 / \mathrm{kWh}$ for wind, $\$ 0.03 / \mathrm{kWh}$ weighted average direct energy rate for solar that correlates with the resource availability, and $\$ 0.046 / \mathrm{kWh}$ for geothermal and biomass projects, which can provide base load power.

The marginal and blended energy rates at Dugway Proving Ground are remarkably low compared to other DoD sites and as a result, many renewable energy projects will struggle to be cost-effective even when the resource could be considered moderate to strong when compared to other regions of the nation. However, Dugway Proving Ground is at the end of its electric feeder and power outages, which are not uncommon, have left Dugway Proving Ground reliant on fossil fuel powered backup generators. This problem is further magnified by Dugway Proving Ground's relatively high reliance on electricity for space and water heating. Provided this clear sensitivity and relatively high likelihood of energy disruption, there is a strong case for developing renewable energy infrastructure from an energy security standpoint.

Lastly, Dugway Proving Ground is in close proximity to Tooele Army Depot and Camp Williams, a National Guard Training Site. Because of this arrangement, there may be potential for joint development of renewable resources to share power from a larger-scale generating project. That option may be worth exploring if: 
- The sites all purchase relatively expensive power and may be able to aggregate their consumption to justify a larger-scale project such as a geothermal plant, a waste-to-energy plant, or a solar array,

- The sites can combine resources (e.g., biomass or municipal waste) to allow for the construction of a larger power plant that might otherwise be uneconomic to construct,

- The sites can leverage purchasing economies of scale and make bulk purchases of renewable energy generation equipment (e.g., PV panels) as well as potential contracting and construction discounts.

\section{State Incentives for Renewable Project Development}

Utah has several state incentives for renewable energy systems including:

- A production tax credit for wind, geothermal, electric, and biomass systems (it does not include waste-to-energy),

- An industry recruitment credit,

- A sales tax exemption for wind, solar, biomass, landfill gas, and geothermal electricity,

- A utility rebate program.

The tax credit is for $10 \%$ of installed costs up to $\$ 50,000$ for wind, geothermal electric and biomass systems less than $660 \mathrm{~kW}$ and is $\$ 0.0035 / \mathrm{kWh}$ for 4 years for systems above $660 \mathrm{~kW}$. Commercial systems include solar thermal and solar electric, wind, direct use geothermal, geothermal (ground source) heat pumps, geothermal electricity, and biomass systems. Biomass systems for heating are not included.

The industry recruitment credit covers solar electric, wind, biomass, and geothermal electric technologies. The credit is called the Renewable Energy Development Incentive and provides relief of taxes up to $100 \%$ of new state taxes including state, corporate, sales taxes and withholding taxes over the life of the project (5 to10 years).

The state of Utah also provides an exemption from sales taxes of renewable energy resource facilities larger than $20 \mathrm{~kW}$. Eligible facilities include those generating electricity from wind, solar, biomass, landfill gas, and geothermal resources. The exemption expires June 30, 2019 (State of Utah 2009).

The utility rebate program applies only to photovoltaics. Rocky Mountain Power provides a \$2/watt rebate up to $\$ 30,000$ for non-residential systems. The program has a total of $107 \mathrm{~kW}$ that is allowed per program year and any given system cannot be larger than $25 \mathrm{~kW}$ AC.

The state of Utah also has a net metering law that requires investor-owned and cooperative utilities to purchase electricity from small generators (systems smaller than $25 \mathrm{~kW}$ ). Utilities only need to take electricity up to 0.1 percent of cumulative generating capacity based on the utilities' peak demand. Electricity from solar and wind are the only generating assets allowed to participate (Utah Geological Survey 2009). 
Utah's renewable portfolio standard (RPS), “The Energy Resource and Carbon Emission Reduction Initiative” (S.B. 202), provides a goal for utilities to obtain $25 \%$ of their electricity supply from renewable energy resources by 2025. However, utilities only need pursue renewable resources if they are "cost-effective". The law specifies what constitutes cost-effectiveness for the renewable resources including the lowest cost of generated electricity. There are no interim goals, but utilities must provide progress reports every 5 years starting in 2010. Consequently, between the costeffectiveness definition and the lack of interim goals, the Utah RPS provides no near-term incentive for developing renewable energy resources. Eligible renewable energy technologies include: solar water heating, solar space heat, solar thermal electric, photovoltaics, landfill gas, wind, biomass, hydroelectric, geothermal electric, combined heat and power/cogeneration, hydrogen, anaerobic digestion, small hydroelectric, tidal energy, wave energy, and ocean thermal. The electricity must be produced within the Western Electricity Coordinating Council, which includes: Washington, Oregon, Idaho, Wyoming, Utah, Arizona, most of New Mexico, most of Colorado, most of Montana, and the lower halves of British Columbia and Alberta.

RECs can be purchased to satisfy some or all of the renewable portfolio target. Although the RPS does not specifically comment on which RECs are eligible, they are likely the same renewable technologies that are listed in the RPS. Likewise, the RPS does not specifically comment on where the RECs must be sourced. Under the right conditions (e.g., when a RPS unconditionally mandates an increased use or in-state production of renewable energy), RECs can be sold to make a project cost-effective when it may otherwise be uneconomical. However, because Utah's RPS does not firmly require an expansion of Utah's renewable energy capacity or the purchase of specific RECs (e.g., solar PV RECs or RECs produced in state), the RPS will not likely result in an increased use of renewable energy.

Additional details about these state-specific incentives can be found in Appendix A.

Federal Incentives for Renewable Project Development

Federal incentives for renewable energy include investment tax credits (ITC) for corporations, significantly accelerated depreciation of equipment, and production tax credits (PTC). Depreciation for most renewable energy equipment qualifies for accelerated depreciation. Available tax incentives reduce the first-year costs of qualified renewable projects. The lower first cost also reduces the amount of money that must be borrowed to develop a project and thus, the associated interest and carrying costs. The combination reduces the delivered cost of power if developed by a private party with a tax obligation. Government-owned projects do not benefit from tax-based incentives. All of the PPA analyses conducted in this report assume that the PTC and other tax credits will be available when the equipment is placed in service.

A 30\% ITC is available for photovoltaic (PV) projects, and $10 \%$ for geothermal and biomass electricity projects, with no incentive limits. The credits may be taken on equipment placed in service prior to January 1, 2017. The renewable energy PTC, originally established in 1992, provides a tax credit for each kWh of electricity produced. The PTC is $2.1 \mathrm{\$} / \mathrm{kWh}$ in 2007 for wind, geothermal and closed-loop biomass (biomass that is grown with the sole purpose of being used to generate energy), and can be taken for 10 years. The PTC is $1.0 \$ / \mathrm{kWh}$ for electricity produced from open-loop biomass and municipal solid waste resources, and can be taken for 5 years. Solar electricity generation has been excluded for equipment placed in service after December 2005, because of the inclusion under the investment tax credit. The PTC has been allowed to lapse and then been renewed several times. The tax basis for depreciation must be reduced by the amount of 
any Federal subsidy used in the financing of the eligible equipment. For solar, wind, and geothermal, the modified accelerated cost recovery system (MACRS) provides for 5-year recovery of the cost of equipment. The 5-year recovery period does not apply to biomass or WTE equipment. 


\section{Results and Recommendations}

A summary of analysis results is presented in Table 3 for Dugway Proving Ground, broken down into economically feasible (green), less favorable (yellow), or nonviable/uneconomic (red) projects. Note that for Dugway Proving Ground, only one project, ground source heat pumps, was determined to be economically feasible (green). Solar PV and geothermal power were determined to only have secondary potential. If electric rates rise sufficiently or there is a breakthrough in a technology, these renewable energy resources may become practical. The underlying analyses and recommendations for each of these technologies and potential projects are provided in the following subsections.

Table 3: Summary of Dugway Proving Ground Renewable Energy Opportunities

\begin{tabular}{|c|c|c|c|c|c|c|c|c|}
\hline & \begin{tabular}{|c|} 
Renewable \\
Resource and \\
Technology \\
\end{tabular} & $\begin{array}{l}\text { Resource } \\
\text { Estimate }\end{array}$ & $\left|\begin{array}{c}\text { Earliest } \\
\text { Output }\end{array}\right|$ & Figures of Merit & $\begin{array}{c}\text { Financing } \\
\text { Mechanisms } \\
\text { Evaluated } \\
\end{array}$ & Location--Requirements & Key Assumptions & $\begin{array}{l}\text { Next Steps } \\
\text { Comments }\end{array}$ \\
\hline 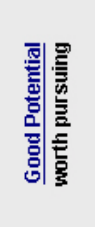 & $\begin{array}{l}\text { Ground } \\
\text { Source Heat } \\
\text { Pump } \\
\text { (Thermal } \\
\text { Energy) }\end{array}$ & TBD & 2011 & $\begin{array}{c}1.0-20 \mathrm{SIR}, 0.8-14 \\
\text { year payback }\end{array}$ & $\begin{array}{l}\text { ECIP } \\
\text { IPP } \\
\text { UESC }\end{array}$ & $\begin{array}{c}\text { Adequate heat sources } \\
\text { and sinks proximate to } \\
\text { GSHPs }\end{array}$ & $\begin{array}{l}\text { There are buildings } \\
\text { that require heating } \\
\text { and potentially cooling. } \\
\text { Suitable land area and } \\
\text { soil characteristics for } \\
\text { closed loop GSHPs. }\end{array}$ & $\begin{array}{l}\text { Site surveys to } \\
\text { determine whether } \\
\text { suitable heat sinks } \\
\text { and sources exist, } \\
\text { and to provide the } \\
\text { detailed soil } \\
\text { characterization to } \\
\text { base system design. }\end{array}$ \\
\hline \multirow{2}{*}{ 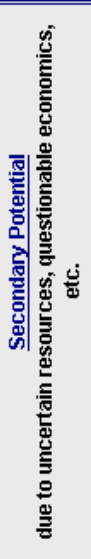 } & $\begin{array}{l}\text { Utility-Grade } \\
\text { Solar Electric } \\
\text { Power Plant }\end{array}$ & $\begin{array}{l}100 \mathrm{KW}-1 \\
\text { MW (or } \\
\text { more if } \\
\text { space is } \\
\text { available) }\end{array}$ & 2012 & $\begin{array}{c}10 \% \text { IPP scenarios }= \\
32-36 \% \text { wh wi } 17- \\
24 \% \text { capacity factor } \\
\\
\text { ECIP scenarios } w / \\
4.68 \% \text { Wh }=\text { negative } \\
\text { IRR, } 0.0-0.1 \mathrm{SIR}, 100 \\
+ \text { year payback }\end{array}$ & $\begin{array}{l}\text { ECIP } \\
\text { IPP }\end{array}$ & $\begin{array}{l}\text { Small scale: rooftops } \\
\text { (especially when } \\
\text { replacing rooftops), open } \\
\text { ground areas with } \\
\text { minimal shading or } \\
\text { concerns over } \\
\text { vandalism. } \\
\text { Large scale: near high } \\
\text { voltage transmission } \\
\text { lines, adequate open } \\
\text { space for array and } \\
\text { inverter system }\end{array}$ & $\begin{array}{l}\text { Proposed project will } \\
\text { not interfere with any } \\
\text { on-site systems. }\end{array}$ & $\begin{array}{l}\text { PVvia an ECIP is not } \\
\text { viable. Wait until a } \\
\text { renewable portfolio } \\
\text { standard (RPS) is } \\
\text { enacted, electric } \\
\text { rates increase, or PV } \\
\text { capital costs } \\
\text { decrease }\end{array}$ \\
\hline & $\begin{array}{l}\text { High } \\
\text { Temperature } \\
\text { Geothermal } \\
\text { Generation }\end{array}$ & $5 \mathrm{MW}$ & 2013 & $\begin{array}{c}10 \% \text { IPP scenarios = } \\
11.4 \% \text { Wh wi } 96 \% \\
\text { capacity factor } \\
\\
\text { ECIP scenarios } w \\
4.6 \% \text { Wh = negative } \\
\text { IRR, } 0.2 \mathrm{SIR}, 48 \text { year } \\
\text { payback }\end{array}$ & $\begin{array}{l}\text { ECIP } \\
\text { IPP }\end{array}$ & $\begin{array}{l}\text { Temperatures }>100^{\circ} \mathrm{C} \text { at } \\
\text { depths less than } 3 \mathrm{~km} \text {, hot } \\
\text { water or steam flow rates }> \\
1000 \text { gpm, heat flow rates } \\
=80 \mathrm{~mW}^{2}\end{array}$ & $\begin{array}{l}\text { High temperatures, fluid } \\
\text { flow, and heat flows are } \\
\text { available at economic } \\
\text { depths. }\end{array}$ & $\begin{array}{l}\text { Geothermal resource } \\
\text { may be available, but } \\
\text { verification } \\
\text { equipment is too } \\
\text { costly to risk not } \\
\text { finding a valuable } \\
\text { resource at current } \\
\text { market conditions }\end{array}$ \\
\hline \multirow{3}{*}{ 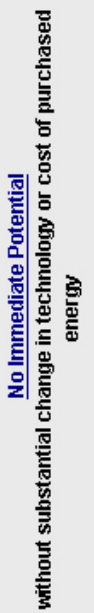 } & $\begin{array}{l}\text { Biomass } \\
\text { Generation } \\
\text { Plant }\end{array}$ & $\begin{array}{l}0.2 \text { MW of } \\
\text { available } \\
\text { biomass }\end{array}$ & 2012 & $\begin{array}{l}\text { Resource availability } \\
\text { is too limited to } \\
\text { perform a meaningful } \\
\text { analysis }\end{array}$ & $\begin{array}{l}\text { Appropriated } \\
\text { funds }\end{array}$ & $\begin{array}{l}\text { A 5-acre site near major } \\
\text { rods, a utility substation, } \\
\text { water, sewage, and an } \\
\text { appropriate industrial } \\
\text { infrastructure, plus } \\
\text { feedstock storage space }\end{array}$ & $\begin{array}{l}\text { Off-site crops will be } \\
\text { available for } \$ 20 \text { per } \\
\text { ton, sufficient on-site } \\
\text { storage is available }\end{array}$ & $\begin{array}{l}\text { Do not pursue this } \\
\text { technology unless } \\
\text { there is a substantial } \\
\text { increase in } \\
\text { agricultural activity }\end{array}$ \\
\hline & $\begin{array}{l}\text { Utility Grade } \\
\text { Wind Farm \& } \\
\text { Small-Scale } \\
\text { Wind }\end{array}$ & $\begin{array}{c}1.5 \mathrm{MW} \\
\text { installed } \\
\text { capacity at } \\
25 \%\end{array}$ & 2012 & $\begin{array}{c}10 \% \text { IPP scenarios = } \\
13.9 \phi / W W h \text { wi } 24 \% \\
\text { capacity factor } \\
\\
\text { ECIP scenarios } w / \\
2.6 \phi / K W h: W / 24 \%= \\
\text { negative IRR \& } S I R, \\
235 \text { year payback } \\
\end{array}$ & $\begin{array}{l}\text { ECIP } \\
\text { IPP }\end{array}$ & $\begin{array}{l}\text { The highest annual } \\
\text { average wind speed was } \\
\text { found in the Wig } \\
\text { Mountain, Simpson } \\
\text { Buttes, Camel's Back } \\
\text { Ridge area of the } \\
\text { installation. }\end{array}$ & $\begin{array}{l}\text { Proposed project will } \\
\text { not interfere with any } \\
\text { on-site systems. }\end{array}$ & $\begin{array}{l}\text { If incentives become } \\
\text { available or there is a } \\
\text { rate increase, the } \\
\text { feasibility of a wind } \\
\text { project should be } \\
\text { reevaluated }\end{array}$ \\
\hline & $\begin{array}{l}\text { Municipal } \\
\text { Waste-to- } \\
\text { Energy Plant } \\
\text { using } \\
\text { Combustion } \\
\text { or Gasification } \\
\text { Technology }\end{array}$ & $6 \mathrm{MW}$ & 2013 & $\begin{array}{l}\text { Break-even cost of } \\
\text { electricity. } 7.12 \phi k W h\end{array}$ & $\begin{array}{l}\mathrm{ECIP} \\
\mathrm{IPP}\end{array}$ & $\begin{array}{l}\text { A } 5 \text {-acre site near major } \\
\text { roads, a utility } \\
\text { substation, water, } \\
\text { sewage, and an } \\
\text { appropriate industrial } \\
\text { infrastructure }\end{array}$ & $\begin{array}{l}\text { Adequate MSW for the } \\
\text { plant sized selected. } \\
50 \% \text { of tipping fees } \\
\text { available with MSW to } \\
\text { plant. }\end{array}$ & $\begin{array}{l}\text { Confirm waste } \\
\text { availability and } \\
\text { tipping fees. } \\
\text { Economics are highly } \\
\text { dependent upon } \\
\text { tipping fee available } \\
\text { from waste providers. }\end{array}$ \\
\hline
\end{tabular}




\section{Ground Source Heat Pump Findings and Recommendations}

The cost-effectiveness of retrofitting existing buildings with GSHPs on Dugway Proving Ground was evaluated using the Facility Energy Decision System (FEDS) building energy modeling program and information gathered during a weeklong site audit conducted in 2009. The analysis was completed for open-loop, horizontal closed-loop, and vertical closed-loop GSHPs for all buildings at Dugway Proving Ground.

Ground-source heat pumps were generally found to be appropriate for Dugway Proving Ground. These findings are predominantly driven by the low cost of electricity at Dugway Proving Ground coupled with the relatively high cost of the only other available fossil fuel types, propane and fuel oil. Open-loop systems were found to be the most cost-effective, and should be considered to potentially increase the number of economic projects and associated savings from the renewable resource. The approval process for installing an open-loop GSHP should be investigated in detail. Horizontal closed-loop systems should be used wherever land will likely not be disturbed. Paybacks range from 1 to 13 years for a variety of buildings, including laboratory research buildings, barracks, administrative centers, child development centers, and the non-privatized housing. Buildings that had particularly positive results included the Materials Test Facility, the Life Sciences Building, and the child development center.

The economic viability of GSHPs is influenced by many factors, including energy prices, local climactic and soil conditions and the characteristics of the candidate buildings. At Dugway Proving Ground, the value of the displaced heating energy plays the most important role in determining costeffectiveness. Detailed results are provided in Appendix D.

\section{Solar Energy Findings and Recommendations}

Dugway Proving Ground is endowed with a strong solar resource. However, the high capital cost of solar power technology coupled with the site's low electricity rate makes solar energy only marginally economic. With current electricity prices, solar photovoltaic (PV) projects did not prove economic. Of the technologies evaluated, axis-tracking PV proved to be the most economic option. See Table 4 for details.

Table 4: Economic Results for Solar PV Technologies at Dugway Proving Ground

\begin{tabular}{|l|c|c|c||}
\hline & $\begin{array}{c}\text { Ground-Mounted } \\
\text { Fixed-Tilt PV }\end{array}$ & $\begin{array}{c}\text { Ground-Mounted } \\
\text { Axis-Tracking PV }\end{array}$ & $\begin{array}{c}\text { Building-Integrated } \\
\text { Roof-Mounted PV }\end{array}$ \\
\hline $\begin{array}{l}\text { Equipment Cost } \\
\text { Assumptions (\$/kW) }\end{array}$ & $\$ 6,450$ & $\$ 7,800$ & $\$ 5,550$ \\
\hline SIR & 0.083 & 0.103 & 0.084 \\
\hline Simple Payback (yr) & 160 & 130 & 155 \\
\hline $\begin{array}{l}\text { Cost of Electricity at } \\
\mathbf{1 0 \%} \text { IRR (\$/kWh) }\end{array}$ & 35.9 & 32.0 & 33.8 \\
\hline
\end{tabular}

Because of the area's moderately high solar resource, Dugway Proving Ground should continue to monitor the market conditions affecting solar energy. Advances in PV technology are expected to produce less expensive solar technology, although rising demand may negate some of these advances. Rising energy rates may do the most to tip the scales in favor of solar electric. Appendix E describes the detailed analysis. 


\section{Geothermal Power Plant Findings and Recommendations}

The resource analysis for Dugway Proving Ground found moderate potential for utility-grade geothermal electricity production, although there is no potential for a cost-effective project at current market conditions. The biggest factor in the capital cost is the number of expensive wells required to produce adequate hot water and steam resources at sufficient flow rates. The ECIP analysis based upon electricity valued at $4.6 \$ / \mathrm{kWh}$ yielded a payback period of 48.2 years, with an SIR of 0.2 . An SIR of 1.25 is generally required for ECIP projects. Under the IPP scenario, the IRR is $2.81 \%$ with energy valued at $4.6 \$ / \mathrm{kWh}$. To achieve a $10 \%$ IRR (minimum IRR for an IPP), the value of the energy generated would need to be $11.4 \$ / \mathrm{kWh}$. The resource estimations need to be confirmed with actual well data and further geological studies. Further study is required to determine the actual drilling costs and depth required to reach a temperature of $150^{\circ} \mathrm{C}\left(302^{\circ} \mathrm{F}\right)$. Detailed results are provided in Appendix C.

\section{Biomass Findings and Recommendations}

The potential biomass resources near Dugway Proving Ground are crop residue, animal waste, and methane from wastewater treatment plant sludge. At this time, dedicated energy crops are not available, and given the climate of the area, are unlikely as future resources. In addition, the potentially available crop residue from conventional crops is sufficient to support only a $0.2 \mathrm{MW}$ plant, a plant size far too small to be practical. Lastly, the volume of wastewater generated at Dugway Proving Ground and the surrounding area does not produce sufficient methane for an economic project. Because of the scale of typical biomass plants, the lack of resource, and the relatively small size of Dugway Proving Ground's average electrical load, biomass plants are not economically feasible at this time. See Appendix B for more details.

\section{Wind Energy Findings and Recommendations}

The wind resource at Dugway Proving Ground does not appear to be sufficient to provide for an economically feasible wind project. With a wind speed of $6.5 \mathrm{~m} / \mathrm{s}$, a commercial energy cost of $13.9 \$ / \mathrm{kWh}$ would be required to provide a $10 \%$ IRR. When evaluated for ECIP funding, the SIR is less than zero and the payback is over 200 years. A small-scale wind project was also considered at Dugway Proving Ground. While small-scale turbines contribute just a small amount of electricity, they may provide other benefits. Installing a wind turbine can immediately bring attention from the community to a site's commitment to renewable energy. However, given the higher capital costs per installed watt for small-scale wind turbines compared to large-scale turbines and the low cost of energy at Dugway Proving Ground, small-scale wind would not be cost-effective either. This analysis is detailed in Appendix F.

\section{Waste-to-Energy Findings and Recommendations}

There is one active landfill on Dugway Proving Ground in addition to two additional landfills approximately 50 miles off site. Combined, these plants could supply 590,000 tons of waste per year, which is equivalent to $65 \mathrm{MW}$ of potential power. Typical waste-to-energy plants are on the order of tens of MW, which is well in excess of Dugway Proving Ground's average load. All waste in the area was evaluated for economic feasibility as either a combustion, gasification, or plasma melting WTE project. Only combustion WTE projects were found to be remotely economic. The

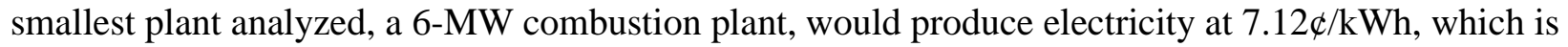
more than Dugway Proving Ground's current average electricity cost of $4.6 \mathbb{C} / \mathrm{kWh}$. For a worthwhile 
landfill gas project, the landfill must have at least 1 million tons in place, be at least 30-feet deep, receive at least 25 inches of rain annually, and be lined. Because Dugway Proving Ground receives only about 18 inches of precipitation per year and the landfill currently only holds 138,000 tons of waste, utilizing landfill gas as a source of renewable energy is not feasible. Detailed results are provided in Appendix B.

\section{Analysis of Renewables at Dugway Proving Ground Bibliography}

Utah State Tax Commission. 2009. “Utah Corporation Franchise or Income Tax Return.” 2008: TC20. http://tax.utah.gov/forms/. Last update September 30, 2009. Accessed 10/6/2009

Utah Geological Survey. 2009. “Renewable Energy Incentives: State Incentives - Utah State Renewable Energy Systems Tax Credit.

http://geology.utah.gov/sep/incentives/rincentives.htm\#retaxcred. Accessed 10/5/2009 


\section{APPENDIX A}

\section{Business Case Analysis Approach}


Renewable Energy Opportunities at Dugway Proving Ground, UT Pacific Northwest National Laboratory, May 2010 


\section{Appendix A: Business Case Analysis Approach}

\section{Overall Basis for Project Economic Feasibility}

The renewable projects considered in this analysis need to compare favorably against the future commercial price of electricity to be purchased by the Dugway Proving Ground to be economically feasible. Dugway Proving Ground obtains its electricity from Rocky Mountain Power.

Rocky Mountain Power provides electricity on a time of use basis with seasonal components plus demand charges based on peak demand. Summer rates occur during May through September, with on-peak hours occurring during 1300 to 2100 hours, Monday through Friday. Winter peak hours occur 700 to 2300 hours, Monday through Friday. On-peak and off-peak summer rates were $\$ 0.034643 / \mathrm{kWh}$ and $\$ 0.02176 / \mathrm{kWh}$, respectively, as of June 2009. On-peak and off-peak winter rates are $\$ 0.026049 / \mathrm{kWh}$ and $\$ 0.02176 / \mathrm{kWh}$, respectively. Demand charges include a facility charge of $\$ 1.65 / \mathrm{kW}$, a summer demand charge of $\$ 10.40 / \mathrm{kW}$, and a winter demand charge of $\$ 7.05 / \mathrm{kW}$. Past bills have also included customer efficiency charges of approximately $\$ 0.02 / \mathrm{kWh}$. A $4 \%$ rate increase was included for 2010 based on communications with Rocky Mountain Power.

Rocky Mountain Power supplied about 39,153 MWh to Dugway Proving Ground with the minimum peak power demand of 5.3 MW in October 2008 and the maximum of 6.9 MW in July. The largest average demand occurred in July at $5.1 \mathrm{MW}$, and the minimum in November at 3.9 MW.

Solar and wind renewable energy resources depend on meeting the direct energy charge, while geothermal and waste-to-energy need to compare favorably against the average avoided cost including demand charges. We used a direct energy rate of $\$ 0.026 / \mathrm{kWh}$ for wind, $\$ 0.03 / \mathrm{kWh}$ weighted average direct energy rate for solar that correlates with the resource availability, and $\$ 0.046 / \mathrm{kWh}$ for geothermal and biomass projects.

All but one of the analyses was conducted using the Financial Analysis Tool for Electric Energy Projects financial analysis model (FATE2-P), described later in this appendix. The analysis for ground-source heat pumps was conducted using the Federal Energy Decision System (FEDS) model, also described in this appendix.

\section{Analytic Approaches}

In assessing the economic feasibility of renewable energy projects at Dugway Proving Ground, PNNL generally evaluated two business case alternatives, (1) investment by an independent power producer (IPP), and (2) Energy Conservation Investment Project (ECIP) funding. These two funding sources have the best returns on Federal investments among the available alternatives. Two other alternatives were examined when conditions were also favorable, (3) the utility energy services contract (UESC), and (4) the energy saving performance contract (ESPC).

Under an IPP scenario, an independent power producer will generally fund, construct, and operate a renewable energy facility, selling power into the competitive marketplace and/or directly to the site that hosts the energy project. This scenario is generally economic when the third-party investor can take advantage of substantial Federal and state incentives. The incentives depend on the type of renewable energy and may include production tax credits, investment tax credits, substantially accelerated tax depreciation of assets, reductions in sales taxes, and exemption from property tax. 
The Energy Conservation Investment Program (ECIP) is one standard DoD approach for making energy efficiency and renewable energy investments using Federally appropriated funding. ECIP investment awards are made based upon savings to investment ratio (SIR) and simple payback (SPB) criteria. ECIP funding is limited, and is awarded on a competitive basis within the Army - only the most economic projects can be assured funding. The approach used in the analyses follows the Federal life-cycle cost methodology (LCC) and procedures in 10 CFR, Part 436, Subpart A. The LCC calculations are based on the Federal Energy Management Program (FEMP) discount rates and energy price escalation rates updated on April 1, 2008.

The utility energy services contract and the energy saving performance contract are very similar approaches, where a third-party invests in an energy project on the Federal facility in return for a share of the energy savings that result. The major difference is that under an UESC, the third-party is a utility_-generally the utility providing energy to the Federal facility. Under ESPC, the investment party is a non-utility, generally an engineering firm that specializes in energy projects. Under UESC and ESPC, the third-party must be repaid out of each year's operational dollars, and the investment must be repaid within the lifetime of the asset. Generally, UESC is more feasible than ESPC because utilities can obtain capital less expensively than can the ESPC contractor. But not all utilities fund UESC projects and the types of projects funded may be limited, opening the door for ESPC. The UESC/ESPC cannot generally capture depreciation or tax incentives that would be afforded an independent power producer.

\section{Independent Power Producer Assumptions}

In addition to capital and operating costs, project feasibility for the IPP is dependent on Federal and state tax incentives, interest rates, inflation rates, and required rates of return discussed in the following sections.

\section{Federal Incentives for Renewable Energy}

Federal incentives for renewable energy include investment tax credits for corporations, significantly accelerated depreciation of equipment, and production tax credits. Combining the incentives with attractive market prices can, in certain cases, lead to feasible renewable energy projects.

\section{Tax Credits}

A 30\% business energy tax credit is available for photovoltaic projects and small-scale wind; large wind, geothermal and biomass electricity generation projects qualify for production tax credits, geothermal and biomass electricity also qualify for an investment tax credit (JCT 2007) but both cannot be taken at the same time. Financial crisis emergency legislation lengthened the investment tax credit period by 8 years to January 1, 2017 from its previous end of December 31, 2008 (H.R. 1424). There are no incentive limits for solar and geothermal electric. Wind is NOT eligible for the business energy tax credit. The tax basis for depreciation must be reduced by the amount of any Federal subsidy used in the financing of the eligible equipment (26 USC § 48). The basis of the facility is eligible for $50 \%$ of the total energy tax credit taken (JCT 2007).

\section{Depreciation}

Most renewable energy equipment qualifies for significantly accelerated depreciation using the modified accelerated cost recovery system (MACRS). According to 168(e)(3)(B)(vi), most renewable energy production facilities would qualify for 5-year accelerated depreciation (US Treasury 2007). 
Table A-1 provides the depreciation rates used in the model for 5-year property. The rates reflect the use of the 3/4-year convention. The basis is reduced by 50\% of any energy investment tax taken (JCT 2007).

Table A- 1: MACRS Depreciation Rates for Renewable Energy Projects

\begin{tabular}{||c|c|c|c|c|c||}
\hline Year 1 & Year 2 & Year 3 & Year 4 & Year 5 & Year 6 \\
\hline $35 \%$ & $26 \%$ & $15.6 \%$ & $11.01 \%$ & $11.01 \%$ & $1.38 \%$ \\
\hline \hline
\end{tabular}

\section{Production Tax Credits}

The renewable energy production tax credit (PTC) provides a per-kWh-produced tax credit for electricity generated. The PTC is $2.1 \mathrm{k} / \mathrm{kWh}$ in 2007 for wind, geothermal, and closed-loop biomass (biomass that is grown with the sole purpose of being used to generate energy) and can be taken for 10 years. The PTC is $1.1 \mathrm{k} / \mathrm{kWh}$ for electricity produced from open-loop biomass and municipal solid waste resources and can be taken for 5 years. Solar electricity generation has been excluded for equipment placed in service after December 2005 (H.R. 6111 2006). The PTC has been allowed to lapse and then been renewed several times (DSIRE 2008). All of the analyses assume it will be available when the equipment is placed in service.

\section{Utah specific incentives and taxes}

Utah has several state incentives for renewable energy systems including:

- A production tax credit for wind, geothermal, electric, and biomass systems (it does not include waste-to-energy),

- An industry recruitment credit,

- A sales tax exemption for wind solar, biomass, landfill gas, and geothermal electricity,

- A utility rebate program.

The tax credit is for $10 \%$ of installed costs up to $\$ 50,000$ for wind, geothermal electric and biomass systems less than $660 \mathrm{~kW}$ and is $\$ 0.0035 / \mathrm{kWh}$ for 4 years for systems above $660 \mathrm{~kW}$. Commercial systems include solar thermal and solar electric, wind, direct use geothermal, geothermal (groundsource) heat pumps, geothermal electricity, and biomass systems. Biomass systems must produce electricity or fuel. Biomass systems for heating are not included.

The industry recruitment credit covers solar electric, wind, biomass, and geothermal electric technologies. The credit is called the Renewable Energy Development Incentive and provides relief of taxes up to $100 \%$ of new state taxes including state, corporate, sales taxes and withholding taxes over the life of the project ( 5 to 10 years). The state determines the development zones on a case-bycase basis, but one requirement is that the local government must be willing to give up some or all of the property taxes. 
The state of Utah also provides an exemption from sales taxes of renewable energy resource facilities larger than $20 \mathrm{~kW}$. Eligible facilities include those generating electricity from wind, solar, biomass, landfill gas, and geothermal resources. The exemption expires June 30, 2019 (State of Utah 2009).

The utility rebate program applies only to photovoltaics. Rocky Mountain Power provides a \$2/watt rebate up to $\$ 30,000$ for non-residential systems. The program has a total of $107 \mathrm{~kW}$ that is allowed per program year and any given system cannot be larger than $25 \mathrm{~kW}$ AC. The rebate is only available after applications are received and accepted.

The state of Utah also has a net metering law that requires investor-owned and cooperative utilities to purchase electricity from small generators from systems smaller than $25 \mathrm{~kW}$. Utilities only need to take electricity up to 0.1 percent of cumulative generating capacity based on the utilities' peak demand. Once participation meets the cap, the utility does not have to allow net metering. The net metering only allows offsets in future bills for excess electricity supplied, essentially providing the supplier with credits for future use. Electricity from solar and wind are the only generating assets allowed to participate (Utah Geological Survey 2009).

A sales tax of 5.95\% (Utah State Tax Commission 2009a) was applied where appropriate. State corporate taxes of $5 \%$ were applied in cases, such as waste-energy facilities and facilities that are in a development zone, which required state taxes to be applied (Utah State Tax Commission 2009b). A property tax rate of $1.1 \%$ was assumed (Utah State Tax Commission 2008) in cases where they were not exempt.

Utah's renewable portfolio standard (RPS), “The Energy Resource and Carbon Emission Reduction Initiative” (S.B. 202), provides a goal for utilities to obtain $25 \%$ of their electricity supply from renewable energy resources by 2025 . However, utilities only need pursue renewable resources if they are "cost-effective." The law specifies what constitutes cost-effectiveness for the renewable resources including the lowest cost of generated electricity. There are no interim goals, but utilities must provide progress reports every 5 years starting in 2010. Thus, between the cost-effectiveness definition and the lack of interim goals, the Utah RPS provides no near-term incentive for developing renewable energy resources. Eligible renewable energy technologies include: solar water heating, solar space heat, solar thermal electric, photovoltaics, landfill gas, wind, biomass, hydroelectric, geothermal electric, combined heat and power/cogeneration, hydrogen, anaerobic digestion, small hydroelectric, tidal energy, wave energy, and ocean thermal. The electricity must be produced within the Western Electricity Coordinating Council, which includes: Washington, Oregon, Idaho, Wyoming, Utah, Arizona, most of New Mexico, most of Colorado, most of Montana, and the lower halves of British Columbia and Alberta.

Lastly, RECs can be purchased to satisfy some or all of the renewable portfolio target. Although the RPS does not specifically comment on which RECs are eligible, they are likely the same renewable technologies that are listed in the RPS. Likewise, the RPS does not specifically comment on where the RECs must be sourced. Under the right conditions (e.g., when a RPS unconditionally mandates an increased use or in-state production of renewable energy), RECs can be sold to make a project cost-effective when it may otherwise be uneconomical. However, because Utah's RPS does not firmly require an expansion of Utah's renewable energy capacity or the purchasing of specific RECs (e.g., solar PV RECs or RECs produced in state), the RPS will not likely result in an increased use of renewable energy. 


\section{Other Independent Power Producer Assumptions}

The minimum after-tax internal rate of return used in the analysis of IPP opportunities was 10\%. The typical after-tax rate of return for most third-party developers is closer to $15 \%$, but there appears to be a suite of renewable energy developers willing to accept a lower return. Both costs and prices were assumed to escalate with an inflation rate of $1.8 \%$.

\section{Energy Conservation Investment Projects}

The assumptions for ECIP are driven by the Federal Energy Management Program. Table A-2 lays out the discount rates underlying the model as of April 2008. The real and nominal rates for DOE/FEMP imply a 1.8\% inflation rate. New rates were obtained from Rushing and Lippiatt (2009).

Table A- 2: Discount Rate Assumptions in the ECIP Model

\begin{tabular}{|r|c|c|c|c|c|c||}
\hline Discount Rate & DOE FEMP & OMB 3-year & OMB 5-year & OMB 7-year & OMB 10-year & OMB 30-year \\
\hline Real & $3.0 \%$ & $2.1 \%$ & $2.3 \%$ & $2.4 \%$ & $2.6 \%$ & $2.8 \%$ \\
\hline Nominal & $4.9 \%$ & $3.9 \%$ & $4.1 \%$ & $4.2 \%$ & $4.4 \%$ & $4.7 \%$ \\
\hline
\end{tabular}

\section{FATE2-P Model Description}

The FATE2-P (Financial Analysis Tool for Electric Energy Projects) financial analysis model was used to evaluate the feasibility of renewable energy projects at Dugway Proving Ground. The spreadsheet model was developed by Princeton Economic Research, Inc. and the National Renewable Energy Laboratory for the U.S. Department of Energy. FATE2-P can be used to develop pro forma financial statements for a utility using a revenue requirements approach or an independent power producer using the discounted rate of return approach. Both approaches are diagrammed in Figure A-1.
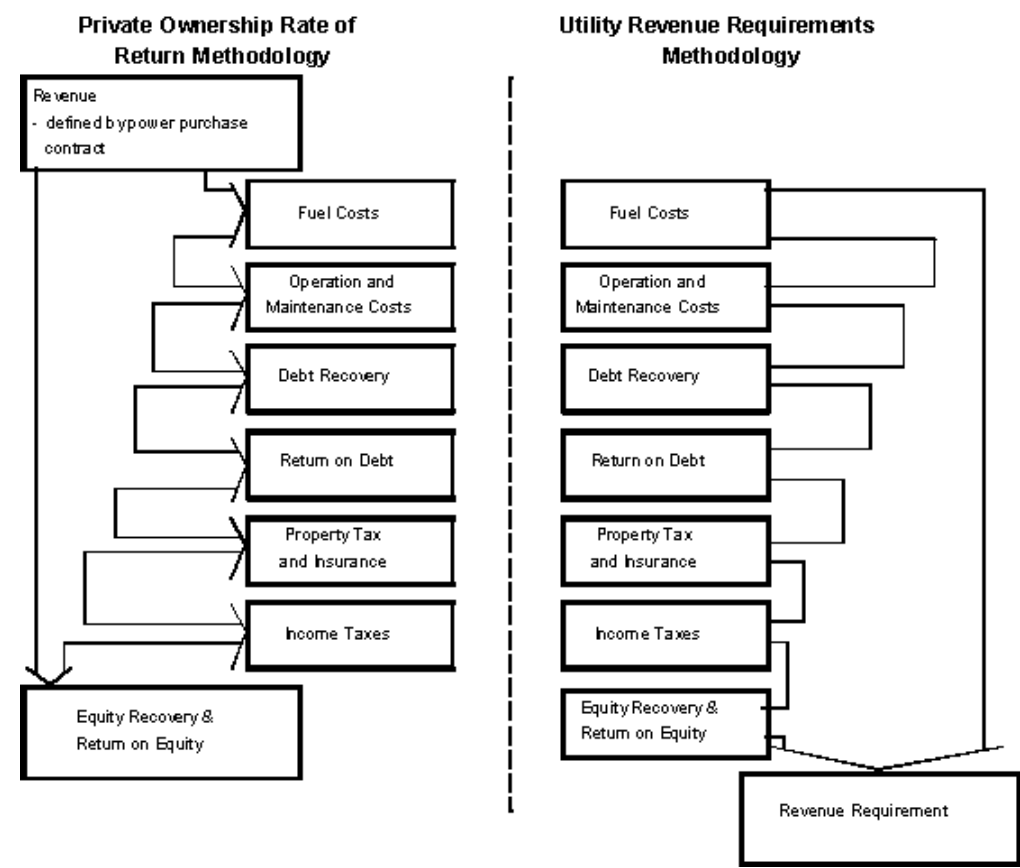

Figure A- 1: FATE2-P Methodology 
Other models produce very similar results given the same inputs. The revenue requirements approach follows a cost-based utility revenue requirements analysis, and the independent power producer approach uses a market-based discounted cash flow return. The FATE2-P model has been updated by PNNL to include the MILCON Energy Conservation Investment Program Module in addition to the rate of return methodology. The model has been used to model improved technology designs, resource variability, and favorable tax treatment on renewable energy products. The advantage this model over other models is that it is already suited for handling all of the renewable energy technologies in this study through one model, thus providing results on a comparable basis across all technologies.

\section{Private Ownership Rate of Return Methodology}

The private Ownership Rate of Return Module (independent power producer) develops an annual after-tax cash flow based on the revenues defined in the power purchase contract and costs associated with constructing and operating the generation facility. The goal of this approach is to capture the relevant investment costs after-tax and compare them with the net cash flow from the investment after-tax over time. The model contains sections to capture the relevant costs of construction including the debt and equity capital accumulation to purchase the investment and the associated payback of debt and equity capital. In addition, the model has sections associated with revenue generation, cash flow, an income statement, and associated statements to calculate tax liabilities to capture after-tax cash flow. The financing section includes several pertinent sections including sources and uses, construction and debt accumulation, reserve funds requirements, debt schedule, amortization of debt fees, and debt service coverage ratios.

- The sources and uses of funds section shows the allocation of construction funds between components and sources of those funds. Uses of funds include construction cost, AFUDC (allowances for funds used during construction), and underwriters' fees for both debt and equity.

- The construction and debt accumulation statement is capable of handling a 6-year construction period starting at any date. Any construction draw schedule can be used for 1 to 6 years. An equal percentage draw schedule for each year of any given construction length is the default.

- The model contains major maintenance and debt-service reserve funds. Both types of accounts generate interest income that becomes a part of the income statement through a drawn-off interest calculation. The model does not currently calculate a working capital reserve account. Such an account would add interest costs to the cost statement in addition to the interest costs on the capital investment.

- The debt schedule allows three types of financing: level payment, bullet, and customized. Level payment is customary for projects that have adequate cash flow to satisfy debt coverage payments and are of short duration. Customized is required when certain years fall below the minimums set by the investment banking industry.

- Cash flow statements can be constructed for up to 30 years of revenue generation plus the 6year construction period. 
- The Revenue Module contains a variable capacity factor, which must be filled in by the analyst to capture depletion of the geothermal fields, the capacity of wind or of the other renewables' capacities. This section also allows for secondary energy by-product credits (such as for steam if it has value), and up to six different types of subsidy payments if available. The model also accepts after-tax production credits, if available, and includes any interest on reserves.

- Cash expenses statements include standard operations and maintenance costs (both fixed and variable), general and administrative expenses, insurance, and land fees. There is major maintenance expense along with a reserve fund dedicated to covering the major maintenance expense when it occurs. Up to two different fuel costs can be entered. There is also an entry for royalty fees associated with geothermal power.

- The earnings statement in this model calculates earnings and taxes based on a tax table. Operating income is calculated by subtracting cash and operating expenses from revenue as described in the section above. Taxable income is determined by subtracting cash and noncash expenses such as interest, depreciation, amortization of fees, IDC (interest during construction), and depletion allowances. Taxes paid and tax credits received are netted and after-tax book income is calculated. The net taxes paid become a part of the cash flow.

- $\quad$ The model includes straight-line and MACRS (modified accelerated cost recovery system) depreciation approaches, with mid-quarter convention deprecation tables. Straight-line allows for the calculation of book basis value of assets and liabilities, while MACRS allows for the taxable basis of the investment.

- $\quad$ The model amortizes debt related fees over 15 years and equity organizational fees over 5 years. Equity tax advice is expensed in the first year, and equity broker fees are excluded.

- The model calculates depletion allowances on geothermal power projects. The model also depletes certain AFUDC when appropriate.

- Income tax and other tax statements are prepared for Federal and state taxes paid as well as tax credits earned. Tax calculations include excise taxes, Federal, state and local taxes. Depreciation calculations used to capture after-tax cash flow can use either straight-line or MACRS. There is also a section to incorporate local property taxes and special tax assessments.

- Assumptions: The assumptions section is fairly extensive and covers construction costs, debt acquisition, equity acquisition, capacity factors, fixed and variable operations and maintenance (O\&M) inputs, financial factors such as interest rates, general and administrative expenses, real escalation in O\&M charges, unfired fuel assumptions, byproduct credits, asset life, inflation rates, tax rates, property tax rates, insurance, investment tax credits, AFUDC, local gross receipts tax, and special property tax assessments.

- Total plant cost (overnight) is divided into sales tax; rotor, gearbox, generator; tower and civil work; controls, transformer, interconnect; design/engineering; 
permitting/environmental, construction labor and supervision; contingency; home office overhead; real escalation in construction cost; miscellaneous depreciable cost (last year of construction); sales tax on miscellaneous depreciable cost; land cost; and startup cost.

\section{ECIP Module}

The FATE2-P model includes a life-cycle cost module based on the Buildings Life Cycle Cost (BLCC) model (produced by the National Institute for Standards and Time (NIST)) and a MILCON Energy Conservation Investment Program (ECIP) Module, which in turn fills out Form 1391. The ECIP module currently reflects 2009 forecast discount and inflation rates. The ECIP module provides first year savings, simple payback, total discounted operational savings, savings-toinvestment ratio (SIR), and adjusted internal rate of return.

\section{The Federal Energy Decision System (FEDS) Model}

FEDS is a building energy modeling software developed by Pacific Northwest National Laboratory to support the economic analysis of efficiency technologies at large, multi-building sites. Building characteristics are entered into the model using as much detail as possible, and the model uses the given information to make inferences for the remaining characteristics. Multiple sets of building data can be entered into the same model, so that an entire site can be represented at once. The optimization cycle uses data about the location of the site and the energy prices entered into the model to determine cost-effective retrofits for each set of building data, and to calculate costs and savings. The suggested retrofits can range from lighting to building envelope to HVAC, covering all aspects of a building's energy use and considering interactive effects. In addition, the model can be adjusted to consider just one type of retrofit. In this renewable analysis conducted at Dugway Proving Ground, ground source heat pumps were the only technology analyzed.

\section{Business Case Analysis Bibliography}

DSIRE. 2008. Federal Incentive for Renewables and Efficiency: Business Energy Tax Credit. http://www.dsireusa.org/library/includes/incentive2.cfm?Incentive_Code $=$ US02F \&State=federal\&currentpageid=1\&ee=1\&re=1. Accessed 12/12/2008.

H.R. 1424. October 2008. “Emergency Economic Stabilization Act of 2008. “Enrolled Bill.”

H.R.6111. December 2006. “Tax Relief and Health Care Act of 2006” (Enrolled as Agreed to or Passed by Both House and Senate). Section 207

Joint Committee on Taxation (JCT). October 4, 2007. "Description of the Chairman's Modification to the Provisions of the "Heartland, Habitat, Harvest and Horticulture Act of 2007," (JCX-96-07)

Rushing, Amy S. and Barbara C. Lippiatt. May 2009. "Energy Price Indices and Discount Factors for Life-Cycle Cost Analysis - April 2009: Annual Supplement to NIST Handbook 135 and NBS Special Publication 709. NISTIR 85-3273-24 (Rev. 5/09).”.

State of Utah. 2009. "Utah Code, Title 59, Chapter 12, Section 104 - Revenue and Taxation, Sales and Use Tax Act, Exemptions. http://www.le.utah.gov/UtahCode/getCodeSection?code=59-12-104. Accessed 10/5/09. 
United States Code Service. 16 USC § 796 (2006). Title 16. Conservation. Chapter 12-Federal Regulation and Development of Power. Subchapter 1. Regulation of the Development of Water Power and Resources. Definitions.

United States Code. 26 USC § 48. Title 26. Internal Revenue Code. Subtitle A. Income Taxes. Chapter 1. Normal Taxes and Surtaxes. Subchapter A. Determination of Tax Liability. Part IV. Credits Against Tax. SubPart E. Rules for Computing Investment Credit.

United States Code Service. 26 USC § 168 (2006). Title 26. Internal Revenue Code. Subtitle A. Income Taxes. Chapter 1. Normal Taxes and Surtaxes. Subchapter B. Computation of Taxable Income. Part VI. Itemized Deductions for Individuals and Corporations

U.S. Department of Treasury. 2007. “2007 Instructions for Form 4562: Depreciation and Amortization (Including Information on Listed Property.” Internal Revenue Service.

Utah Geological Survey. 2009. “Renewable Energy Incentives: State Incentives - Utah State Renewable Energy Systems Tax Credit.

http://geology.utah.gov/sep/incentives/rincentives.htm\#retaxcred. Accessed 10/5/2009

Utah State Tax Commission. April 2009a, “Utah Code Tile 59, Chapter 12, Sales \& Use Tax Act.” http://tax.utah.gov/sales/rates.html. Accessed 9/6/2009

Utah State Tax Commission. 2009. “Utah Corporation Franchise or Income Tax Return.” 2008: TC20. http://tax.utah.gov/forms/. Last update September 30, 2009. Accessed 10/6/2009

Utah State Tax Commission. 2008 “2008 Tax Areas/Tax Rates.”

http://propertytax.utah.gov/taxrates/approvedtaxareaindex.html. Last updated October 27, 2008. Accessed 10/6/2009 


\section{APPENDIX B}

\section{Analysis of Biomass and Waste-to-Energy Opportunities}


Renewable Energy Opportunities at Dugway Proving Ground, UT Pacific Northwest National Laboratory, May 2010 


\section{Appendix B: Analysis of Biomass and Waste-to-Energy Opportunities}

\section{Biomass and Waste-to-Energy Technology}

The term "biomass" refers to renewable fuels used for power production that include agricultural waste, forest and wood processing waste, animal waste, industrial waste, dedicated biomass crops, and methane from landfills and wastewater treatment plants. Waste-to-energy (WTE) is similar, but includes municipal solid waste (MSW) and construction and demolition (C\&D) waste as fuel sources. These feedstocks qualify as renewable sources for Energy Policy Act of 1992 (EPAct) compliance purposes, but some states and alternative goals have different feedstock requirements. While biomass and WTE projects may be very different as to their sources, fuel collection modes, and fuel cost profiles, in the end, energy production often relies on similar technologies.

The primary technologies for producing electricity rely upon steam turbines, gas turbines, or combined-cycle turbine generators. Generators are energized by steam produced from direct combustion of raw material, or a synthetic gas (syngas) produced through anaerobic digestion or gasification. Direct combustion and anaerobic digestion technologies are mature and have been proven commercially. Coal plants typically use combustion technologies, and biomass (typically wood) can be cofired with coal for a more simple renewable energy option. Gasification technologies are newer in the market, but are promising based on a number of successful installations. Anaerobic digestion is widely used but primarily for smaller applications in rural and municipal projects rather than large commercial installations.

The capital cost of biomass plants ranges from about $\$ 1,500$ to $\$ 7,000 / \mathrm{kW}$, depending upon scale and specific technologies used. Direct combustion technologies tend to be both larger and less capital-intensive than those based on syngas. Digesters tend to have a higher unit cost, primarily because of their smaller size. Cofiring equipment is typically an order of magnitude less than a new combustion or gasification plant. Operation and maintenance (O\&M) for digesters is also more expensive, costing about $2.0 \$ / \mathrm{kWh}$, compared to about $1.0 \$ / \mathrm{kWh}$ for combustion plants. There is little change in O\&M for cofiring, although there may be costs associated with preprocessing the wood waste. The advantage for digesters is the low cost of fuel, which is typically free local waste (e.g., sewage sludge, manure). Even a "free" feedstock such as crop wastes, which is not currently collected nor located at one site, does not guarantee a successful project, because collection, transportation, and storage costs can be, and often are, economically prohibitive. The economics of MSW projects are typically more attractive than other biomass projects because fuel is often delivered free or even accompanied by payment in the form of a tipping fee. Most landfills are operated or franchised by a local government. Many of these derive operating revenues from fees that are added to the actual operating costs of the landfill. As a result, the tipping fee may be inflated over actual costs and therefore not an accurate representation of costs that can be avoided.

Combustion (direct-fired) systems burn biomass to produce steam in a boiler, turning a turbine connected to a generator. This method of producing electricity is quite inefficient, at about 20 to $30 \%$. In direct-fired systems, combustion products tend to form deposits on the heat transfer surfaces, increasing maintenance requirements and decreasing the lifetime of these surfaces as a result of corrosion and erosion. Ash has to be collected and removed from the system. The variability of incoming feedstock in terms of its composition and moisture content can present problems in combustion systems, most notably with MSW and mixed feeds. Systems that use a more homogeneous feedstock benefit from more complete combustion, which increases efficiency and reduces combustion waste products and emissions. Various boiler designs try to address these issues. 
Gasification is more efficient than combustion, but the technologies employed are not as mature or common in commercial operation. The two basic types of gasification are direct-fired (aerobic) and indirect-fired (anaerobic). Gasification uses oxygen (direct-fired systems only), steam, heat, and pressure to break down organic materials to produce syngas, which is primarily hydrogen and carbon monoxide. Syngas is cleaned to remove impurities, then is used to generate electricity in a gas turbine or fuel cell, or is used to produce transportation fuels and/or commercially valuable chemicals. The syngas resulting from direct-fired systems has a lower heating value than the syngas from indirect-fired systems, and requires significant upgrading and processing to be used as fuel. The inorganic materials are discharged as inert solids that can often be used for another purpose. There are many types of gasification designs that use different amounts of oxygen and steam at different stages and temperatures, producing different amounts of waste heat, syngas, and solids.

As mentioned, biomass can be added to replace a fraction of coal used in an existing combustion or gasification plant. This is a common practice with minimal capital cost involved, compared to standalone biomass or WTE systems. There is also less risk involved because the feedstock is mixed with a feedstock that has already been functioning well in an existing system, reducing the chances of clogging or other operational issues. However, a feedstock with similar properties to coal must be used; a consistently uniform size and heat content is important, so wood waste is typically the feedstock of choice.

Plasma melting is one gasification process just now entering the commercial market for use with MSW. Although it has a short track record, it is worth considering because of its positive attributes for use on a military facility. The plasma melter uses a plasma torch to decompose the material being gasified, resulting in a much higher temperature and more complete reaction. This new technology produces only syngas from the organics, molten metal from any metals, and a hard glass-like substance from the inorganics. Gaseous emissions are released and scrubbed to remove pollutants, and the solid waste can be sold and used for other commercial purposes, such as construction material. Ash collected from syngas cleaning can be fed back into the plasma melter. Hazardous materials can also be gasified in this process, sealing the toxic substances into the solid waste with no potential for leaching (EvTEC 2002).

Digesters tend to be smaller systems and are typically used just for biomass. They are usually located at the biomass source, such as farms with significant amounts of animal manure and wastewater treatment facilities. Digesters break down biomass in warm, wet environments to produce methane, which can be captured as fuel for generating electricity. Aerobic digesters are common in developing countries for production of heating and cooking fuel in rural areas. Anaerobic digesters limit the amount of oxygen in the gasification process, producing gas with a higher concentration of methane, which is better for power production. Because of the smaller size of digester systems, electricity is typically generated using fuel cells, microturbines, or reciprocating engines.

Methane is also produced through anaerobic digestion in landfills as the garbage underground breaks down. Traditionally, this methane has been left in the ground, but the risk of fire and greenhouse gas emissions has led the Environmental Protection Agency (EPA) to require landfills to remove the methane. The methane could be used in an electricity generation system if the economics are positive. The most economic opportunities for landfill methane capture and use are in cases where the landfill collects municipal solid waste (MSW), already has a collection system in place, is active or recently closed (methane production tapers off as landfills age), and has sufficient waste (typically at least 1 million tons) to generate a significant amount of methane. The landfill must be lined to 
prevent water intrusion into the landfill that stifles digestion of the waste and methane production and to prevent the methane from migrating into the surrounding soil. New landfills are typically lined by regulation; many older ones are not. Methane production even from large landfills is relatively low; as a result, power facilities that use it are typically small systems located on-site using fuel cells, microturbines, or reciprocating engines.

For all of these technologies, except landfill gas, a power plant will require feedstock storage space, feedstock preparation equipment, feed equipment, processing equipment, product cleaning and collection equipment, electricity generation equipment, ash and waste storage space, water for steam and cooling, and emissions control equipment. The specific infrastructure and space required for each of these depends on the type of feedstock and process used, the amount of feedstock used, and existing site conditions. As an example, one plasma gasification project evaluated could process 250 tons of MSW in an 80-foot by 175 -foot area, not including storage space. However, permanent systems with infrastructure typically need up to 5 acres. Any existing electrical generation equipment may possibly be used as part of the new system, reducing site requirements, and thus requiring only space next to the existing system for the new equipment and connection lines.

Some feedstocks require year-round storage because they are only available seasonally (e.g., crop residue); some feedstocks are available almost continuously and require less storage space (e.g., MSW). In case of supply interruption, a plant will need to store enough material from a continuously available feedstock to provide fuel for about 20 days. This storage requirement could use about 40 acres of land, depending on the overall size of the plant. Some feedstocks can be compressed into uniform-sized pellets, to simplify storage, transport, and combustion. However, the pelletization process can increase fuel costs by $20 \%$. Storage areas may have to be located some distance away from the plant because of site constraints. However, nearby storage is preferred to reduce operational costs.

Emissions control requirements depend upon the process used and on regulations affecting the site. Some gasification processes (with gas scrubbers) produce no criteria pollutants, such as sulfur oxides $\left(\mathrm{SO}_{\mathrm{X}}\right)$ and nitrogen oxides $\left(\mathrm{NO}_{\mathrm{X}}\right)$. However, air emissions are inevitable if the resulting syngas is burned in a conventional power generator.

\section{Biomass and Waste-to-Energy Analysis Approach}

The critical factor in determining feasibility for biomass energy generation is feedstock availability. There are a number of potential feedstocks that were evaluated for use at Dugway Proving Ground. The following questions were asked about each feedstock:

- Does this material exist in the surrounding region within 60 miles? (30 to 60 miles is assumed to be the maximum economic transport distance.)

- How much is available within this area, on average? Is availability constant or variable, dependent on crop rotation cycles and/or market conditions?

- How much is available for use as a feedstock? Availability is based on the feedstock being able to be collected and the lack of competing uses or markets. For example, wheat straw is typically left in the field to protect and rebuild the soil. If it is collected, the resulting bales may have higher value as animal bedding than as fuel, creating a competing market for what was otherwise a waste material on the ground. 
- How much electricity can be produced from the available biomass? This is a function of the quantity of material available, moisture content, and its relative heat value.

In this analysis, if the capacity of a power plant using a feedstock was less than $1 \mathrm{MW}$, it was not considered a feasible feedstock resource. The narrowed list of possible feedstocks was then evaluated on a simple economic basis. Feedstock costs were estimated based on tipping fees, collection costs, transportation costs, current market rates, and other relevant information. Other operational costs and construction costs were estimated by scaling existing plant data for the three primary technology types. Based on the amount of feedstock available and the size of plant required, a levelized cost of electricity was estimated for each.

For options that are reasonably close to being cost-effective, further economic analysis was completed, including evaluating tax credits and other incentives, different financing options, ranges of potential construction and operation costs, and ranges of feedstock costs and amounts. Dugway

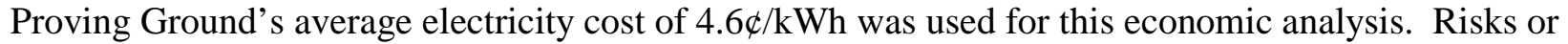
potential issues associated with these remaining options were noted so as to present all considerations surrounding an implementation decision. When possible, these were quantified.

PNNL staff created a new tool that supports analyses of various plant sizes, costs, and fuel sources in a generic manner. This facilitates "what if" analyses where critical information about fuel source and cost is unavailable. The result is an estimate of what power from a project would cost using available data and staff assessments for missing data. It also allows staff to reverse engineer an answer given Dugway Proving Ground's power cost. Specifically, the tool can be set up to provide an estimate of what size plant and fuel cost is needed to produce power for less than the current and projected future power rate. Data from a 2003 National Renewable Energy Laboratory (NREL) study of biomass fuels (Bain 2003) was used to initiate the analytic tool. The 2003 study costs were converted into 2007 dollars and scaled according to varying plant sizes following the methodology used in the study. Any size plant can be evaluated, and any value can be varied to test for financial feasibility. The tool was only used for preliminary screening because it does not adequately address taxes, incentives, or other factors. These economic factors have a significant impact on project feasibility, especially if it is assumed the power project is not owned and operated by the government.

This analytic approach was used to evaluate all biomass options, without making preliminary assumptions about feedstocks or technologies. In other words, it was used to develop preliminary estimates of electric generation costs using a "What if feedstock X were available?" The results of this preliminary analysis are useful for framing a biomass or WTE strategy. If the analysis resulted in estimated costs that are highly uneconomic, the option was rejected.

\section{Biomass and Waste Resource Characterization}

The following biomass and waste types were assessed for potential as feedstocks.

- Agricultural (crop residues, animal waste, dedicated biomass crops)

- Forest (thinnings, logging slash)

- Industrial (mill residue, other industry waste)

- Waste (MSW, C\&D waste, landfill gas, biogas or biosolids from wastewater treatment plants) 


\section{Agricultural Biomass}

The USDA has a database of agricultural production information by county and state. Information about corn, wheat, other crops/orchards/vineyards, and poultry, pig, and cow production was collected from this source.

\section{Crop Residue}

Crop residues are the plant remains in the field after harvest. Some crops have more residues than others; some, like hay, have no residues at all because the entire plant is harvested. A certain amount of residue left on the soil minimizes erosion and maintains soil nutrients. However, too much residue can inhibit growth of a new crop. Depending on tilling practices, climate, crop type, soil type, and slope of the land, residue may or may not be available for removal. In general, conventional till practices need more residue than no-till practices; warm wet climates need more residue than cold dry climates; corn fields need more residue than wheat fields; coarse, well-drained soils need more residue than poorly-drained, heavy clay soils; and steeper slopes need more residue than flat land. In addition, crop residue availability is dependent on competing uses, like cattle feed, and seasonal yields, which can change dramatically from year to year.

In 2008, in counties within 60 miles of Dugway Proving Ground, the major crops harvested that leave residues were corn and oats. See Table B-1 for the number of bushels and amount of residue produced on an annual basis. Available residue for biomass energy generation will be somewhere between zero and these values. A rule of thumb is that about $30 \%$ of the residues can be collected. However, these numbers will have to be verified on a farm-by-farm basis for a more accurate analysis.

Table B- 1: Crops and Biomass Production near Dugway Proving Ground

\begin{tabular}{||r|r|r|r|r||}
\hline \hline & $\begin{array}{c}\text { Bushels } \\
\text { Produced }\end{array}$ & $\begin{array}{c}\text { Tons Residue } \\
\text { Remaining }\end{array}$ & $\begin{array}{c}\text { Tons Collectable } \\
\text { Residue }\end{array}$ & $\begin{array}{c}\text { Potential Electricity } \\
\text { Generation }\end{array}$ \\
\hline Corn & 201,200 & 5,568 & 1,670 & $0.2 \mathrm{MW}$ \\
\hline Oats & 14,500 & 290 & 87 & $0.01 \mathrm{MW}$ \\
\hline Total & $\mathbf{2 1 5 , 7 0 0}$ & $\mathbf{5 , 8 5 8}$ & $\mathbf{1 , 7 5 7}$ & $\mathbf{0 . 2} \mathbf{~ M W}$ \\
\hline
\end{tabular}

It would cost about $\$ 10 /$ ton to transport the residues to the biomass plant, and about $\$ 10 /$ ton for the farmer's collection effort. Therefore, the crop residue feedstock cost is about $\$ 20 /$ ton. In addition, residue availability is dependent on competing uses, including cattle feed, which can pay almost \$42/ton for corn stover. The crops also compete against each other based on market demand, and because each crop yields different amounts of residue, the amount of feedstock available will vary. Availability is also dependent on seasonal yields, which can change dramatically.

Sufficient on-site storage of the residue is important to avoid incurring further costs for storage elsewhere. A significant amount of space is required to store crop residue because it is only available twice a year, after harvest.

Even when all the above considerations are ignored, the total potential electricity generation from crop waste is less than $1 \mathrm{MW}$, which is not enough to warrant production of a new generation plant. In addition, annual crop yield varies because of crop rotation, market conditions, and weather patterns such that the volume of crop-specific feedstock is highly variable. This increases the risk that sufficient fuel will not be available on an annual basis. Finally, there are alternative markets for crop residue that provide intervening opportunities in terms of market access (alternative markets are 
closer to the source) and market price. Therefore, it is not recommended to pursue corn or oat residues for electricity production.

\section{Animal Waste}

Manure from cattle, swine, and poultry farms is generally reclaimed from animal housing and feeding areas and used as fertilizer for crops. This has become a problem because of overapplication. Bad odors and groundwater contamination are forcing farmers to find other ways to dispose of manure. Furthermore, greenhouse gas emissions are now more strictly regulated, so emissions from manure must be controlled. Anaerobic digestion technologies can turn wet manure into energy, and often can be used with existing collection and treatment systems. Poultry waste has a lower moisture content than cow or swine manure, and can be used in combustion or gasification systems.

In 2008, there were no known cattle feedlots, swine, or poultry farms within 60 miles of Dugway Proving Ground. Therefore, using animal waste as a feedstock for electricity generation is not an option at this time.

\section{Dedicated Crops}

Dedicated energy crops include switchgrass, hybrid poplar, willow coppice, and other short rotation woody crops (SRWC). Energy crops are fast-growing plants that can be harvested for use as energy in various forms. Switchgrass is a native prairie grass that grows best in warm dry climates like the Midwest. SRWC need a lot of water and do well in colder climates like the Northeast. They need at least 16 inches of rainfall per year, or need to be located near a body of water. Using dedicated crops as biomass is an option, but they are not a readily available resource. Rather, agricultural land where the crops can be grown is the resource to be evaluated, and the feedstock cost would be based on the cost to farm that land, harvest the resource, and deliver it to the generation plant on post.

None of the traditional energy crops are suited to the region near Dugway Proving Ground. The soil and climate do not naturally favor crop growth, and irrigation or other extensive agricultural practices are cost-prohibitive.

\section{Forest Biomass}

\section{Forest Thinnings and Logging Slash}

Logging slash includes branches, stumps, and other material that is generated during logging practices but left behind because it is not useful to the loggers seeking large tree trunks. Once this slash is cut and left on the forest floor, it dries out, becoming good fuel for fires. It also hampers the machinery used during replanting efforts. Sometimes it is gathered into small piles and burned in a controlled manner to reduce the risk of widespread forest fire, but this practice pollutes the air and may be restricted by air quality regulations. Instead, it can be collected and transported to a biomass facility where the emissions can be controlled and the wood waste can be used to generate energy.

There are no forested areas near Dugway Proving Ground. Thus, forest thinnings and slash are not available for use as biomass to generate electricity.

\section{Industrial Biomass}

Industrial biomass includes mill residue, food processing waste, textile waste, or waste from other specialized operations. 


\section{Mill Residue}

There are many types of mills that use wood to produce various products, including lumber, shake and shingle, pulp, veneer and plywood, log chips, and posts, poles, and pilings. These processes generate waste in the form of sawdust and wood pieces, which are useful materials. In fact, most mill residue is currently used for fiber, fuel, or other uses.

There are no mills in the Dugway Proving Ground region because there is no forestry industry. Therefore, mill residue is not a feasible resource.

\section{Other Residue}

There are no large industrial facilities in the Dugway Proving Ground area that generate waste usable for biomass.

\section{Waste Biomass}

\section{Municipal Solid and Urban Wood Waste}

MSW and C\&D waste are being generated at greater rates each year while landfills are filling up, resulting in greater hauling distances and increasing prices for waste disposal. Recycling is one way to reduce the strain on landfills; using the waste to generate energy is another. Some recyclables, like metals, must be separated out before the waste is used for energy generation. All carbon-based materials, however, can be used to generate energy.

Dugway Proving Ground produces approximately 600 tons of MSW per year. This waste used to be collected and disposed of at the on-site landfill, but has been sent off site since July 2008 to help prolong the life of the landfill. Allied Waste is the current waste collection agency sub-contracted to Dugway Proving Ground. The waste is collected and sent to the Wasatch Regional Landfill, and the site is charged a monthly flat fee that includes the collection efforts. C\&D waste is now the primary type of waste collected at the on-site landfill. Because the main components of C\&D waste are typically concrete, asphalt, or other materials that do not break down easily, it was excluded from this analysis.

There is one transfer station within 60 miles of Dugway Proving Ground. The waste collected at the Tooele Transfer Station is sent to the Wasatch Regional Landfill. Waste disposed in this area totals about 590,429 tons per year, and is expected to remain about the same in the future. These collection areas are summarized, with their respective tipping fees, in Table B-2. 
Table B- 2: Waste near Dugway Proving Ground

\begin{tabular}{|l|l|c|c|c|c|c|}
\hline \multicolumn{1}{|c|}{ Site } & $\begin{array}{c}\text { Miles from } \\
\text { Collection } \\
\text { Location } \\
\text { Proving } \\
\text { Ground }\end{array}$ & $\begin{array}{c}\text { Tipping } \\
\text { Fee (\$) }\end{array}$ & $\begin{array}{c}\text { Assumed } \\
\text { Cost } \\
\text { Savings } \\
\text { (\$) }\end{array}$ & $\begin{array}{c}\text { Available } \\
\text { MSW } \\
\text { (tons/year) }\end{array}$ & $\begin{array}{c}\text { Potential } \\
\text { Electricity } \\
\text { Generation } \\
\text { (MW) }\end{array}$ \\
\hline $\begin{array}{l}\text { Dugway Proving } \\
\text { Ground }\end{array}$ & $\begin{array}{l}\text { Dugway } \\
\text { Proving } \\
\text { Ground }\end{array}$ & 0 & $\$ 40^{2}$ & $\$ 40$ & 607 & 0.07 \\
\hline $\begin{array}{l}\text { Tooele Transfer } \\
\text { Station }\end{array}$ & $\begin{array}{l}\text { Tooele, } \\
\text { UT }\end{array}$ & $\sim 50$ & $\$ 42$ & $\$ 21$ & 55,183 & 6.0 \\
\hline $\begin{array}{l}\text { Wasatch Regional } \\
\text { Landfill }\end{array}$ & $\begin{array}{l}\text { North } \\
\text { Skull } \\
\text { Valley }\end{array}$ & $\sim 45$ & $\$ 24$ & $\$ 12$ & 590,429 & 64.7 \\
\hline \multicolumn{7}{|l}{} \\
\hline
\end{tabular}

The assumed cost savings for each site is discounted 50\% from the tipping fee, to account for any additional transportation needs and incentives to deliver waste to a new location. In addition, part of the tipping fees could fund recycling programs in the area, so the city or county would want to retain that portion of the revenue.

Each landfill's waste could be an option for use as feedstock, either separately or in combination with other sources. Depending on contracts, plans, capacity needs, and economic issues at each landfill or transfer station, none or all waste may actually be available. Therefore, other options may need to be considered, including combinations of partial waste from more than one location.

Because of the low amount of potentially available waste and relatively low tipping fees, none of the technologies considered for waste conversion (combustion, gasification, and plasma melting) result in a cost-effective project. A combustion power plant that uses all the waste in the surrounding area proved to be nearly cost-effective. However, such a system would generate over $60 \mathrm{MW}$ of power, which is ten times Dugway Proving Ground's average power demand. While the excess power could be sold back to the utility, this option is unlikely given Dugway Proving Ground's remote location and the limitations of the current high voltage power lines. A smaller-scale project, such as using waste from the Tooele Transfer Station, would be approximately $6 \mathrm{MW}$ in size, would have a capacity factor of $85 \%$, and would produce electricity at a cost of $7.12 \Phi / \mathrm{kWh}$, which is more than Dugway Proving Ground's current average electricity cost of $4.6 \$ / \mathrm{kWh}$. In addition, waste-toenergy is not an eligible technology under Utah's RPS and consequently, no RECs can be sold from such a project. As a result, it is not recommended to further pursue a waste-to-energy project at this time. Changes in electricity rates, modifications in the RPS, and increases in waste processing rates may allow the smaller waste-to-energy project to become cost-effective. Lastly, since waste-toenergy plants are capable of providing base load power and energy, they are suitable to improving the energy security of an instillation.

\section{Landfill Gas}

Methane generated from decomposing waste is a combustible pollutant that must be controlled. It is typically vented or collected and flared to avoid buildup and reduce the chances of an explosion. 
New greenhouse gas regulations are expected to require collection of landfill methane. Collected methane can be used as a fuel to generate heat or electricity.

For a worthwhile landfill gas project, the landfill must have at least 1 million tons in place, be at least 30 -feet deep and lined, and the site must receive at least 25 inches of rain annually. There is one active landfill on-site at Dugway Proving Ground. The landfill consists of two main collection areas, Phases I and II. Phase I currently holds approximately 21,900 tons, while Phase II holds 117,000 tons. The design capacity is estimated at 813,884 tons of waste. The current waste levels are well below the optimal 1 million tons of waste, and even at full capacity, the landfill would not reach the 1 million ton threshold. Furthermore, Dugway Proving Ground receives on average only 18 inches of precipitation annually. Because of the small size of this landfill and the less than optimal weather conditions, a landfill gas project is not feasible.

Executive Order (EO) 13514 was recently signed into law, and requires Federal facilities to report their greenhouse gas emissions and establish reduction targets with the Council on Environmental Quality (CEQ). As a result, more incentives could arise in the future that could make a landfill gas project more economic even under less than optimal operating conditions. However, because of the relatively small size of the Dugway Proving Ground landfill, it is likely that other, more costeffective measures exist to achieve the greenhouse gas reduction requirements (e.g., waste reduction through increased recycling, composting). Furthermore, if the emissions from the landfill comprise a small percentage of the overall site emissions, it may be more beneficial for the site to focus greenhouse gas reduction efforts on other sources of emissions.

\section{Wastewater Treatment Plant (WWTP) Sludge}

WWTP sludge is what remains after wastewater is treated and the clean water is returned to the ground or other body of water. It has a high energy content when dried, but the drying process is energy-intensive and necessary before transportation. Sludge is similar in substance to manure; it is a very watered-down substance that is best processed on-site, where methane is generated with anaerobic digestion. Therefore, only on-site sources of sludge are reasonable to use for energy generation.

The WWTP at Dugway Proving Ground consists of four wastewater-holding lagoons. Of the four lagoons, two are aerated (the English Village and Ditto lagoons), and two are aerobic (Baker and Carr lagoons). Wastewater is collected in these lagoons, where the sludge settles to the bottom. Because of the relatively low volume of processed wastewater, the sludge is not dredged on a regular basis.

To produce $1 \mathrm{MW}$ of power, the annual production of sludge needs to exceed 13,400 tons. Sludge treated in an anaerobic digester becomes cost-effective (with a liberal assumption of no cost for the feedstock) at about $20 \mathrm{MW}$, which would require over 260,000 tons of sludge per year. Considering that New York City produces 143,810 tons of sludge per year, Dugway Proving Ground is nowhere near this sludge requirement. Furthermore, because the sludge from the lagoons is not collected on a regular basis, it would not be possible to guarantee a consistent feedstock source. Therefore, WWTP sludge is not a feasible resource. 


\section{Biomass and Waste-to-Energy: Economic and Other Analysis Parameters}

The availability of crop residue, animal waste, dedicated biomass crops, forest thinnings and logging slash, mill residue, other industrial waste, landfill gas, and WWTP sludge are all inadequate to consider a large biomass generation project. The other potentially available biomass fuel, municipal solid waste, could not support economic electricity generation. As a result, it is not recommended to pursue biomass or waste-to-energy projects at this time.

\section{Biomass and Waste-to-Energy: Next steps}

Because no source of biomass or waste resulted in a cost-effective project, it is not recommended to pursue any biomass or waste-to-energy options at this time. Because of the climate and relative remoteness of the area surrounding Dugway Proving Ground, it is unlikely that feedstock amounts will increase significantly enough in the near future to make a biomass or waste-to-energy project economically feasible. However, it is possible that with rising costs of electricity and/or tipping fees, the economics of a waste-to-energy project could become more attractive and thus a feasible option for Dugway Proving Ground. In such cases, assumptions regarding the amount of available feedstock, equipment capacities, and local cost data for equipment, feedstock, O\&M, and generated electricity would need to be checked. A site would need to be selected, and a developer secured before design and final economic calculations could be completed.

\section{Biomass and Waste-to-Energy References}

Aabakken, J. 2006. “Power Technologies Energy Data Book.” National Renewable Energy Laboratory. Fourth Edition. NREL/TP-620-39728. Golden, Colorado.

Bain, R.L. and W.A. Amos. Biopower Technical Assessment: State of the Industry and Technology. National Renewable Energy Laboratory, Golden, Colorado. 2003.

Bain, RL, WA Amos, M Downing, RL Perlack. 2003. "Biopower Technical Assessment: State of the Industry and Technology.” National Renewable Energy Laboratory, Golden, Colorado. NREL/TP-510-33123.

Burke, Dennis. 2001. “Dairy Waste Anaerobic Digestion Handbook.” Encyclopedia of Animal Science. Environmental Energy Company. http://www.makingenergy.com/Dairy\%20Waste\%20Handbook.pdf.

De La Torre Ugarte, DG, ME Walsh, H Shapouri, and SP Slinsky. 2000 "The Economic Impacts of Bioenergy Crop Production on U.S. Agriculture.” University of Tennessee Agricultural Policy Analysis Center. Knoxville, Tennessee.

Economic Development Corporation of Utah. 2009. “Tooele County Profile 2009”. http://www.edcutah.org/documents/TooeleCountyProfile_011609.pdf .

Energy Information Administration. 2009. "Average Heat Content of Selected Biomass Fuels.” http://www.eia.doe.gov/cneaf/solar.renewables/page/trends/table10.html. Accessed April 2009.

Environmental Protection Agency Landfill Methane Outreach Program. 2009. http://www.epa.gov/lmop/proj/index.htm. 
Gallagher, Paul, et al. 2003. “Biomass from Crop Residues: Cost and Supply Estimates.” United States Department of Agriculture, Office of the Chief Economist. Washington D.C. http://www.usda.gov/oce/reports/energy/AER819.pdf.

Guttentag, Roger M. 1994 “Processing Recyclables: What’s My Line?” WasteAge. http://wasteage.com/mag/waste_processing_recyclables_whats/.

Haq, Zia. 2002. “Biomass for Electricity Generation.” Energy Information Administration. http://www.epa.gov/solar/pdf/haq_apr20.pdf. Accessed June 2009.

IEA Energy Technology Essentials. 2007. “Biomass for Power Generation and CHP.” http://www.iea.org/textbase/techno/essentials3.pdf.

Keetch, Jim, Chief Contracting Officer, Contract Management Division. December 2009. Dugway Proving Ground. Personal communications.

Lamar, David, Integrated Environmental Technologies, LLC. October 2007 Personal communications.

Mason, Jerry, Environmental Programs. Dugway Proving Ground. November 2009. Personal communications.

Research Reports International. 2007. “The Use of Biomass for Power Generation in the U.S.” July 2007.

Sheffey, Steve, Physical Scientist. December 2009. Dugway Proving Ground Water Quality and UST Programs. Personal communications.

Smith, Carl Benjamin, et al. 2007. "Lesser Known Energy Sources: A Study of Biogas and Tire Based Fuel.” Lockheed Martin.

http://www.aeecenter.org/DivisionNewsletters/AREDI/Fall07/biogas-tires.pdf.

Soil Quality National Technology Development Team. 2006. “Crop Residue Removal for Biomass Energy Production: Effects on Soils and Recommendations.” National Resources Conservation Service. Greensboro, North Carolina. http://soils.usda.gov/sqi/management/files/sq_atn_19.pdf.

Stone, Robert, et al. 2000 “Universal Soil Loss Equation (USLE).” Ministry of Agriculture, Food and Rural Affairs. Guelph, Ontario, Canada.

http://www.omafra.gov.on.ca/english/engineer/facts/00-001.htm\#tab2.

Tooele County Department of Solid Waste. 2009. http://www.co.tooele.ut.us/landfill.htm. Accessed November 2009.

Treece, Kirk, Wasatch Regional Landfill Facility Contact. 2009. Personal communications.

United States Department of Agriculture Forest Service. 2009. "Forest Inventory \& Analysis Mapmaker Program on Timber Products Output Studies.” http://www.fia.fs.fed.us/programfeatures/tpo/. Accessed October 2009. 
United States Department of Agriculture Forest Service. Forest Products Laboratory. 2004 Fuel Value Calculator. July 2004.

United States Department of Agriculture National Agricultural Statistics Service. 2009.

http://www.nass.usda.gov/Data_and_Statistics/Quick_Stats/. Accessed October 2009.

United States Environmental Protection Agency. 2009. Landfill Gas Energy Project Development Handbook. Landfill Methane Outreach Program. http://www.epa.gov/landfill/res/handbook.htm. Accessed October 2009.

Utah Department of Environmental Quality Division of Solid and Hazardous Waste. 2009. http://www.hazardouswaste.utah.gov/SWBranch/SWSection/SolidWasteSection.htm\#solidwastefacil ities. Accessed October 2009.

Walsh, Marie E., et al. 2000. "Biomass Feedstock Availability in the United States: 1999 State Level Analysis.” Oak Ridge National Laboratory, Oakridge Tennessee. http://bioenergy.ornl.gov/resourcedata/index.html.

Water Environment Research Foundation. 2008. "Fact Sheet. Wastewater Sludge: A New Resource for Alternative Energy and Resource Recovery.” Alexandria, Virginia

http://www.werf.org/AM/TemplateRedirect.cfm?template=/CM/ContentDisplay.cfm\&ContentID=98 98

Water Environment Research Foundation. 2008. "State of Science Report: Energy and Resource Recovery from Sludge Executive Summary.” Alexandria, Virginia http://www.werf.org/AM/CustomSource/Downloads/uGetExecutiveSummary.cfm?FILE=ESOWSO3R07.pdf\&ContentFileID=7538 


\section{APPENDIX C}

\section{Analysis of Geothermal Plant Opportunities}


Renewable Energy Opportunities at Dugway Proving Ground, UT Pacific Northwest National Laboratory, May 2010 


\section{Appendix C: Analysis of Geothermal Power Plant Opportunities}

Geothermal power plants use steam from hot water reservoirs found deep below the Earth's surface. The steam rotates a turbine that activates a generator, producing electricity. There are three commercial types of geothermal power plants used to generate electricity (dry steam, flash steam, and binary cycle), and several newer technologies are entering the marketplace (hot dry rock and engineered geothermal systems). The type of plant depends on the state of the fluid (whether it is steam, hot water, or mixed) and its temperature.

- Dry steam power plants use underground steam piped directly from wells to the power plant, where it passes through separators to remove small particles before it is directed into a turbine/generator unit. There are only two known underground resources of steam in the United States: The Geysers in northern California and Yellowstone National Park in Wyoming. The only dry steam plants in the country are at The Geysers.

- Flash steam power plants use geothermal resources that produce high-temperature hot water or a combination of steam and hot water. This very hot water (reservoirs greater than $360^{\circ} \mathrm{F}$ or $182^{\circ} \mathrm{C}$ ) flows up through wells in the ground under its own pressure. As it flows upward and the pressure decreases, some of the hot water boils (flashes) into steam. The steam is then separated from the water and used to power a turbine/generator. Any leftover water and condensed steam are injected back into the reservoir, making this a sustainable resource. Depending on the temperature resource, it may be possible to use a second flash tank where more steam at a lower pressure is separated for generation (double flash plant).

- Binary cycle power plants utilize a second fluid in a closed cycle to operate the turbine, instead of direct geothermal steam. These plants operate on water at lower temperatures of about $107^{\circ}-182^{\circ} \mathrm{C}\left(225^{\circ}-360^{\circ} \mathrm{F}\right)$. The heat from the hot water is used to boil a working fluid, usually an organic compound with a low boiling point. The working fluid is vaporized in a heat exchanger and used to turn a turbine. The water is then injected back into the ground to be reheated. The water and the working fluid are kept separated during the whole process, so there is minor or no contamination. The advantage of the binary cycle plant is that it can operate with lower temperature water by using working fluids that have an even lower boiling point than water. Binary power plants are available in smaller-scales such as 200 to $1,000 \mathrm{~kW}$.

- Hot dry rock (HDR) geothermal production utilizes high temperature rocks found deeper (several kilometers) below the surface by pumping high-pressure water down a borehole into a heat zone. The water captures the heat of the rock by traveling through fractures until it is forced out a second borehole and used to generate electricity. Once the water has cooled, it is pumped back underground to heat up again. This process is most easily utilized in locations with natural geothermal systems with existing cracks or pore spaces.

- Engineered/enhanced geothermal systems (EGS) are similar to HDR systems. In locations where there are few cracks and connected pore spaces, or little to no cracks or connectivity, cracks can be created or enhanced. The advantage of HDR or EGS is that geothermal resources can be captured for production in non-tectonically active regions. This technology is still very new and expensive. 


\section{Geothermal Energy Analysis Approach}

This analysis utilized information obtained from geologic maps, geothermal resource maps, previous publications, and thermal spring and well data made available from the Utah Geological Survey, in addition to other readily available sources provided by the Bureau of Land Management (BLM) and the U.S. Geological Survey (USGS), to determine if the following conditions exist that demonstrate utility-grade geothermal potential:

- Existing power plant operation or developer activity

- One or more wells tested with temperatures in excess of $100^{\circ} \mathrm{C}\left(212^{\circ} \mathrm{F}\right)$ logged downhole (at depths less than 3,000 m)

- Demonstrated high fluid flow rates on the order of 1,000 gallons per minute per MW

- Heat flow rates greater than $80 \mathrm{~mW} / \mathrm{m}^{2}$ (milliWatts per square meter)

- Other exploration data and information available that demonstrates underground temperatures in excess of $100^{\circ} \mathrm{C}\left(212^{\circ} \mathrm{F}\right)$

Since the 2005 DoD geothermal assessment, additional research and development has been completed on other geothermal development techniques that may be applicable to additional installations. We attempt to interpret this new information when evaluating the economic viability.

\section{Geothermal Resource Characterization}

Geothermal resources include hot springs, geysers, and underground resources of pressurized water and steam accessible via wells, as well as dry steam, hot water, hot dry rocks, and low-temperature geothermal heat. A known geothermal resource area (KGRA) is a classification used for Federal leasing arrangements based on competitive interests and/or geologic criteria that indicates the presence of a viable geothermal resource.

In Utah, the USGS and the BLM have classified four areas as KGRAs around Dugway Proving Ground (Figure C-1), three of which are used for utility-grade electrical production (Figure C-1). Electrical power has been generated at the Roosevelt Hot Springs and Cove Fort-Sulphurdale KGRAs in southwestern Utah. An additional power plant is under development near the Thermo Springs KGRA. Numerous geological studies and well data have revealed several other areas in the state that have shown potential for geothermal electricity production (Fleischmann 2006). Although these areas are generally concentrated near hot springs, Utah's geology suggests there are hidden geothermal resources without apparent surface manifestations that have yet to be discovered (Fleischmann 2006). 


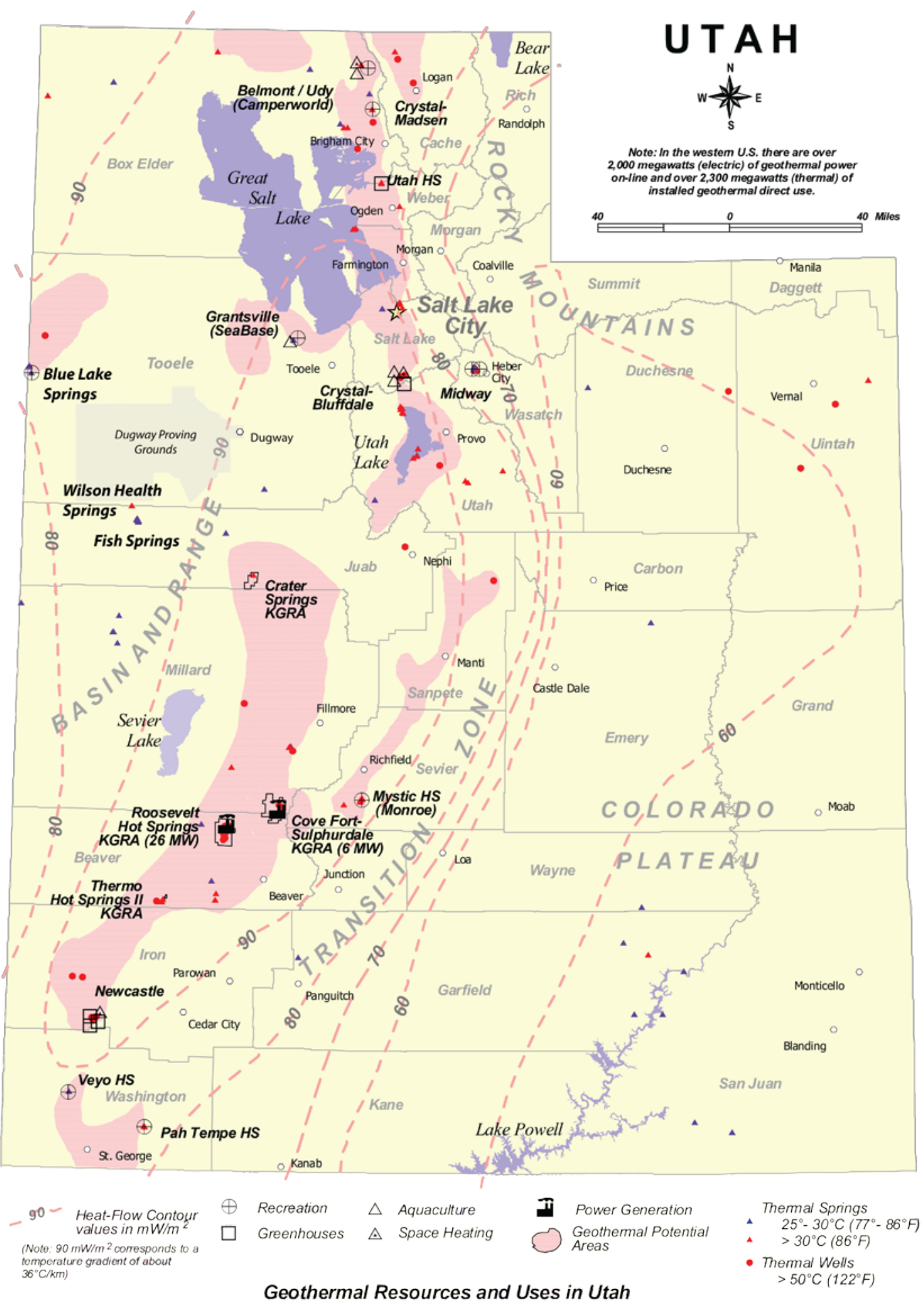

Figure C- 1: Geothermal Resources and Uses in Utah (Utah Geothermal Working Group (UGWG) 2005). 


\section{Regional Geology and Local Geothermal Occurrences}

Dugway Proving Ground lies within the Basin and Range Province, a tectonically active zone of high heat flow and moderate-temperature geothermal resources. Thermal springs and wells near the margins of valleys along active range bounding faults indicate the presence of geothermal activity near Dugway Proving Ground. Low-temperature thermal fluids (i.e., warm water) are present in Blue Lake and Salt Springs, located in western Tooele County near the Utah-Nevada border (Figure C-1). The temperature of the spring feeding Blue Lake is unknown, but the lake maintains a fairly constant temperature of $\sim 29^{\circ} \mathrm{C}\left(84^{\circ} \mathrm{F}\right)$ (Blackett and Wakefield 2002). Published maps of Utah's geothermal resources (Idaho National Laboratory (INL) 2003; UGWG 2005) identify the Blue Lake Springs area as having above average geothermal potential (Figure C-1).

North of the site, several warm springs occur along the margin (i.e., the edge) of Skull Valley and Tooele Valley, with temperatures ranging between $18^{\circ} \mathrm{C}$ to $25^{\circ} \mathrm{C}\left(64-77^{\circ} \mathrm{F}\right)$. A few shallow wells located in Tooele Valley have temperatures in the range of $20^{\circ} \mathrm{C}$ to $31.5^{\circ} \mathrm{C}\left(64-89^{\circ} \mathrm{F}\right)$. The Bonneville Seabase developed at Grantsville Warm Springs is located in Tooele Valley, and is known for its commercial diving and aquaculture use. Published maps of Utah Geothermal Resources (INL 2003 UGWG 2005) identify both the northern portion of Skull Valley and Tooele Valley as having above average geothermal potential (Figure C-1).

Southwest of Dugway, near the Tooele-Juab county border, a series of hot springs occurs along the northeast flank of the Fish Springs Range. The springs are assumed to rise along a fault buried beneath the valley (Mundorff 1970). In 2008, the Utah BLM documented the sale of multiple geothermal exploration leases for parcels along the northern flanks of the Fish Springs Range (BLM 2008). According to the Utah BLM office (McKee 2009, personal communications), no exploration work is currently ongoing or planned in the Fish Springs areas. Wilson Health Springs (Figure C-1), the northernmost and hottest spring in the area, has water temperatures as high as $60^{\circ} \mathrm{C}\left(140^{\circ} \mathrm{F}\right)$ $60^{\circ} \mathrm{C}$. However, analysis of the Wilson Health Springs suggests that reservoir temperatures are less than $100^{\circ} \mathrm{C}\left(212^{\circ} \mathrm{F}\right)$ (Blackett and Wakefield 2002). Lastly, UGWG's maps of Utah Geothermal Resources (INL 2003 UGWG 2005) do not specifically identify Wilson and Fish Springs as having geothermal potential.

The Crater Springs KGRA, one of four listed KGRAs in Utah, is located approximately 40 miles south of Dugway Proving Ground in the northern Sevier desert (Figure C-1). The Crater Springs Geothermal Area lies at the base of Fumarole Butte, an ancient volcano (Galyardt and Rush 1981). Fractures in the central portion of the volcano provide pathways for warm vapors that rise to the surface (Blackett and Wakefield 2002). Also, several hot springs can be found in the KGRA. The highest spring temperatures range up to $87^{\circ} \mathrm{C}\left(189^{\circ} \mathrm{F}\right)$. Geothermometers suggest temperatures in the range of $87^{\circ}$ to $116^{\circ} \mathrm{C}\left(189^{\circ}\right.$ to $\left.241^{\circ} \mathrm{F}\right)$ (Blackett and Wakefield 2002).

Elevated temperatures at the Crater Springs KGRA appear to be associated with an isolated volcanic center. According to published geologic maps (Clark and Oviatt 2008, More and Sorensen 1979), there are no geothermal features that suggest the presence of a localized, high-temperature volcanic heat source near Dugway Proving Ground. However, several fault lines in the immediate area may provide pathways for deep groundwater circulation that could potentially be used for geothermal power near Dugway Proving Ground. 


\section{Reservoir Potential}

For commercial use, it is necessary to have a geothermal reservoir capable of providing hydrothermal (hot water and steam) resources with sufficiently high flow rates. Successful geothermal electrical power generation requires fluid flow rates equal to or greater than 1,000 gpm (gallons per minute) per MW (megawatt). For example, $1.5 \mathrm{MW}$ of electricity at a reservoir temperature of $148^{\circ} \mathrm{C}(300$ ${ }^{\circ} \mathrm{F}$ ) requires a flow rate of about 1,000 gpm, or about 1,029,000 barrels per month (McKenna 2006). The hydrogeologic conditions at potential reservoir depths beneath Dugway Proving Ground are not assessed in this report. Additional hydrogeologic studies and drilling are necessary to gain a reliable estimate for the actual production capabilities at depth.

Geothermal plants need to operate in regions with high heat flow rates. Heat flow values above 80 $\mathrm{mW} / \mathrm{m}^{2}$ (milliWatts/square meter) are considered characteristic of a feasible geothermal resource. Productive heat flows are generally greater than $150 \mathrm{~mW} / \mathrm{m}^{2}$ (Blackwell et al. 2003). Heat flow in the Basin and Range Province typically ranges from 80 to $120 \mathrm{~mW} / \mathrm{m}^{2}$ (Blackett and Wakefield 2002, SMU Geothermal Lab 2004). Very high heat flow anomalies occur locally in proximity to hydrothermal systems such as hot springs. Figure C-1 displays average heat flow contour values for Utah. Dugway Proving Ground is located in an area that ranges from 80 to $90 \mathrm{~mW} / \mathrm{m}^{2}$ (Figure C-1), which is sufficient for geothermal electricity generation.

Conventional utility-grade geothermal energy generally requires temperatures in excess of $150^{\circ} \mathrm{C}$ $\left(302^{\circ} \mathrm{F}\right)($ MIT 2006), although binary cycle plants are able to operate at temperatures as low as $100^{\circ} \mathrm{C}$. The Geothermal Temperature at Depth $(3 \mathrm{~km})$ Map for the Continental United States from Idaho National Laboratory (INL) shows that the temperature ranges from 100 to $160^{\circ} \mathrm{C}\left(212^{\circ} \mathrm{F}\right.$ $320^{\circ} \mathrm{F}$ ) across Dugway Proving Ground. Actual borehole temperature measurements near Dugway Proving Ground are regionally sparse, and are primarily limited to areas of known geothermal resources. In the Bonneville Salt Flats, near Wendover, temperature gradients recorded for brine production wells range from 23 to $117.5^{\circ} \mathrm{C} / \mathrm{km}$. The highest temperature was recorded at $88^{\circ} \mathrm{C}$ $\left(190^{\circ} \mathrm{F}\right)$ in a well drilled to a depth of $631 \mathrm{~m}$. The deepest well was drilled to a depth of $1301 \mathrm{~m}$ and recorded a bottom-hole temperature of $73^{\circ} \mathrm{C}\left(163^{\circ} \mathrm{F}\right)$. Thermal wells located near Grantsville record temperature gradients ranging from 32 to $133^{\circ} \mathrm{C} / \mathrm{km}$. South of Dugway Proving Ground in Whirlwind Valley several deep geothermal exploration wells were drilled in the mid 1970s. Uncorrected temperature gradients (i.e., gradient data not corrected for terrain affects) recorded from these wells range from 22 to $35^{\circ} \mathrm{C} / \mathrm{km}$. Figure C-2 displays a plot of available uncorrected temperature gradients published for wells located in both Tooele and Juab Counties (Blackett 2004). The distribution of temperature gradients recorded from the deepest boreholes (less than $986 \mathrm{~m}$ ), which are generally not influenced by near-surface effects (e.g., precipitation and movement of groundwater), range between 22 to $55.9^{\circ} \mathrm{C} / \mathrm{km}$. Using an average regional temperature gradient of $34^{\circ} \mathrm{C} / \mathrm{km}$ and an average surface temperature of $14^{\circ} \mathrm{C}\left(54^{\circ} \mathrm{F}\right)$, a temperature of $116^{\circ} \mathrm{C}\left(240^{\circ} \mathrm{F}\right)$ can be estimated at a depth of $3 \mathrm{~km}$. 


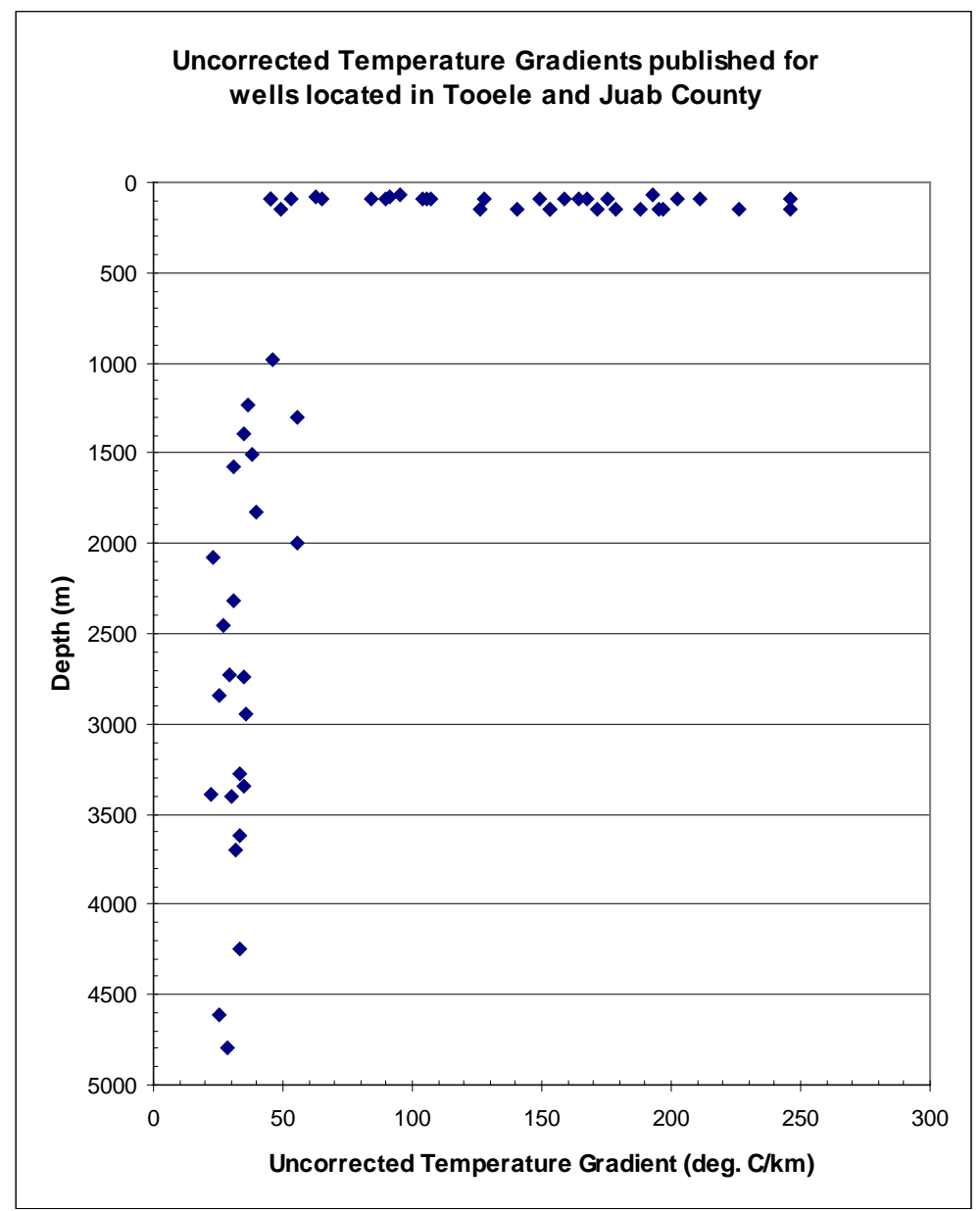

Figure C- 2: Geothermal Temperatures Gradients (Blackett 2004)

\section{Geothermal Power Plants: Economic and Other Analysis Parameters}

This assessment considered the current Federal $(2.1 \mathrm{\&} / \mathrm{kWh})$ and state $(0.4 \mathrm{\$} / \mathrm{kWh})$ renewable energy production credits and a 5-year accelerated depreciation. Utah incentives for geothermal energy include a sales tax exemption and a renewable energy portfolio standard (RPS) (DSIRE 2008). However, the RPS is considered to be more of a "goal" than a firm target and is not likely to strongly impact renewable energy development at this time (see Appendix A for more details). For the sales tax exemption, we are assuming that the assembly of the renewable energy system would meet the exemption requirements. This assumption would need to be checked carefully with the State of Utah. Also, the Federal tax rate of $35 \%$ and Utah state tax rate of $5 \%$ were both included in the analysis.

For the economic evaluation of the geothermal resource potential, the electric rate of $4.6 \$ / \mathrm{kWh}$ was used. The economics were also run to determine the minimum price per $\mathrm{kWh}$ required to earn a sufficient internal rate of return (IRR) for independent power producers. 


\section{Installed Costs of Technology}

Geothermal power costs are influenced by capital costs for land, drilling, and the physical plant. The analysis also needs to consider the cost of operation and maintenance (O\&M), the amount of power generated, and the market value of the power. Capital costs range from $\$ 1,500$ to $\$ 4,000$ per installed kW. Capital costs for flash steam plants tend to be less expensive than binary plants. Plant life spans are typically 30 to 45 years.

Capital costs include:

- Initial development work: land leasing, exploration, permitting, test well costs

- Infrastructure: roads, water supply, utilities

- Well field drilling: production wells in addition to already drilled confirmation wells

- Steam and brine gathering system: pipes and brine separation equipment

- Power plant: physical equipment for energy conversion, including substation

- Interconnection: link of the power plant substation to the transmission corridor

- Soft costs: developers' fees, overhead, financing costs, legal fees, etc.

Geothermal wells are typically drilled to depths of 200 to 1,500 meters for low and medium temperature systems. For high temperature systems, wells are generally drilled 700 to 3,000 meters deep. Each well costs $\$ 1$ million to \$6 million to drill, and a geothermal field may consist between 10 and 100 wells.

Operating plants at over 90\% capacity will result in higher O\&M costs. Larger plant size means lower per-kWh operating costs. Operating costs range from 0.4 to $2.6 \mathbb{\$} / \mathrm{kWh}$ for conventional geothermal power plants.

According to existing data, there is low potential for Dugway Proving Ground to have elevated temperatures at economic depths (less than 3,000 m) for geothermal energy production. The economic analysis was run with an above average regional temperature gradient of $45^{\circ} \mathrm{C} / \mathrm{km}$ and an optimistic temperature of $150^{\circ} \mathrm{C}\left(302^{\circ} \mathrm{F}\right)$ at 3,000 $\mathrm{m}(9842.5 \mathrm{ft})$. A project size of $5 \mathrm{MW}$ was considered, which would require a minimum of two extraction and two injection wells. Drilling costs were estimated based on a total of four wells drilled to approximately 3,000 m (9,843 ft) at a cost of \$2,103 per $\mathrm{m}$ (\$641 per $\mathrm{ft}$ ). The drilling price per-foot was estimated from information obtained from local drilling contractors.

Table C- 1: Performance, Cost, and Economic Characteristics

\begin{tabular}{||l|l||}
\hline Assumed temp. at $3000 \mathrm{~m} \&$ gradient & $150^{\circ} \mathrm{C}, 45^{\circ} \mathrm{C} / \mathrm{km}$ \\
\hline Capacity Factor & $96 \%$ \\
\hline Technology Type & Binary \\
\hline Project Size & $5 \mathrm{MW}$ \\
\hline Estimated Annual Energy Production & $42,000 \mathrm{MWh}$ \\
\hline Average Cost of Energy & $4.6 \$ / \mathrm{kWh}$ \\
\hline Total Capital Cost & $\$ 7,440 / \mathrm{kW}$ \\
\hline \hline
\end{tabular}


Further details on the analysis methodology and the economic and incentive parameters are documented in Appendix A of this report.

\section{Findings: Geothermal Power Plant Opportunities}

The resource analysis for Dugway Proving Ground found moderate potential for utility-grade geothermal electricity production, although there is no potential for a cost-effective project at current market conditions. The biggest factor in the capital cost is the number of expensive wells required to produce adequate hot water and steam resources at sufficient flow rates. The resource estimations need to be confirmed with actual well data and further geological studies.

The ECIP analysis based upon electricity valued at $4.6 \$ / \mathrm{kWh}$ yielded a payback period of 48.2 years, with an SIR of 0.2. An SIR of 1.25 is generally required for ECIP projects. Under the IPP scenario, the IRR is $2.81 \%$ with energy valued at $4.6 \$ / \mathrm{kWh}$. To achieve a $10 \%$ IRR (minimum IRR for IPP to be interested) the value of the energy generated would need to be $11.4 \mathrm{\$} / \mathrm{kWh}$. RECs would need to be sold at $6.8 \$ / \mathrm{kWh}$ to make this project cost-effective. $6.8 \$ / \mathrm{kWh}$ is relatively expensive for a REC and it may be difficult to find buyers for this REC. Lastly, because geothermal power plants are capable of providing base load power and energy, they are suitable to improving the energy security of an instillation.

Based on the geothermal occurrence model discussed in this report, prospective geothermal plant locations may exist along active normal faults that bound the northeastern and southwestern edge of Dugway Valley and the southwestern flank of Granite Peak. Other areas within the Dugway Proving Ground boundary near known hot spring activity (e.g., Wilson Hot Springs, Fish Springs, Blue Lake Springs), do not have transmission line access. Any geothermal power development near these springs would require additional transmission line installation. Lastly, project development on native lands to the north may also lead to development assistance and may be worth exploring. However, the geothermal resource was not deemed to be especially strong in areas immediately north of the instillation.

This assessment, which is focused on utility-scale electricity generation, did not examine the potential for direct use applications of geothermal resources such as aquaculture and industrial processes.

\section{Geothermal Power Plants: Next Steps}

The value of geothermal energy was calculated to be $11.4 \$ / \mathrm{kWh}$ (with a $10 \% \mathrm{IRR}$ ). At the current base-load electricity price of $4.6 \$ / \mathrm{kWh}$, geothermal electric projects are not currently cost-effective. However, as electricity costs increase and efficiencies in drilling and geothermal power production improve; geothermal power at Dugway Proving Ground may become a viable option in the future.

The economic analysis for geothermal electricity at Dugway Proving Ground relied upon many assumptions. The resource data for this assessment is based on an optimistic well temperature and an above average temperature gradient found from wells drilled in the Tooele-Juab county region. Further study is required to determine the actual drilling costs and depth required to reach a temperature of $150^{\circ} \mathrm{C}\left(302^{\circ} \mathrm{F}\right)$. 
Recommended investigations include:

- Field reconnaissance work,

- Temperature and geochemical analysis of local springs and wells,

- $\mathrm{CO}_{2}$ soil gas surveys along faults to help identify areas with upwelling thermal fluids,

- Geophysical surveys to help identify the location of faults at depth,

- Drilling of test wells, which are necessary to accurately characterize the geothermal resource.

Based on the geothermal occurrence model discussed in this report, exploration for viable geothermal resources could be investigated along active normal faults that bound Dugway Valley and the southwestern flank of Granite Peak.

\section{Geothermal Power Plant Sources of Information}

Blackett, R. E. 2004. Geothermal Gradient Data for Utah: Utah Geological Survey Open-File Report. Salt Lake City, Utah. http://geology.utah.gov/emp/geothermal/pdf/utah_temp_grad.pdf

Blackett, R.E., and S. L. Wakefield. 2002. Geothermal resources of Utah: Utah Geological Survey Open-File Report 397, Salt Lake City, Utah.

http:/geology.utah.gov/emp/geothermal/pdf/utgtherm.pdf

Blackwell, David D. et al. 2003. Geothermal Resource Analysis and Structure of Basin and Range Systems, Especially Dixie Valley Geothermal Filed, Nevada. Department of Geological Sciences Southern Methodist University. http://www.osti.gov/energycitations/servlets/purl/813485smnwbs/native/813485.PDF

California Energy Commission. 2003. Renewable Resources Development Report. California Energy Commission Report. Folsom, CA. http://www.energy.ca.gov/reports/2003-11-24_500-03080F.PDF

Campbell, R.G., and M.M. Hatter. 1991. Design and operation of a geopressured geothermal hybrid cycle power plant: Final report vol. I, 180 p. and vol. II, 172. Eaton Operating Company, Inc. and United States Department of Energy, The Ben Holt Co.

Clark, D. L., and C. G. Oviatt. 2008. Interim geologic map of the Dugway Proving Ground and adjacent areas, parts of the Wildcat Mountain, Rush Valley, and Fish Springs 30'x60' quadrangles, Tooele County, Utah (year 2 of 2). Utah Geological Survey Open-File Report 532, Plate 1. http://geology.utah.gov/online/ofr/ofr-532.pdf

DSIRE. 2008. Federal Incentive for Renewables and Efficiency: Business Energy Tax Credit. http://www.dsireusa.org/library/includes/incentive2.cfm?Incentive_Code $=$ US02F\&State=federal\&currentpageid=1\&ee=1\&re=1. Accessed 12/12/2008.

Fleischmann, D. J. 2006. Geothermal Development Needs in Utah. Geothermal Energy Association (GEA). http://www.geo-energy.org/publications/reports/Utah\%20Final\%20PrePublication\%20Report\%20\%20June\%2026.pdf 
Galyardt, G.L., and F.E. Rush. 1981. Geologic map of the Crater Springs Known Geothermal Area and vicinity, Juab and Millard Counties, Utah: U.S. Geological Survey Miscellaneous Investigations Series Map I-1297, scale 1:24,000.

GeothermEx, Inc. 2004. New Geothermal Site Identification and Qualification. California Energy Commission. http://www.geothermex.com/CEC-

PIER_Report_New_Geothermal_Site_Identification_and_Qualification.pdf, Richmond, CA.

Hance, Cédric Nathanaël. 2005. Factors Affecting Costs of Geothermal Power Development. Geothermal Energy Association. http://www.geo-

energy.org/publications/reports/Factors\%20Affecting\%20Cost\%20of\%20Geothermal\%20Power\%20 Development\%20-\%20August\%202005.pdf

Idaho National Laboratory (INL). 2003. Utah Geothermal Resources. Publication No. INEEL/MISC-2002-1617 Rev. 1. November 2003. http://geothermal.inel.gov/maps/ut.jpg

Idaho National Laboratory (INL). 2005. Temperature at Depth Maps for the Continental United States. Estimated Temperature at 3 Kilometers. http://geothermal.id.doe.gov/maps/. Accessed November 2009.

Joost J. Brasz Bruce P. Biederman Gwen Holdmann. 2005. Power Production from a Moderate Temperature Geothermal Resource. GRC Annual Meeting September 25-28th, 2005; Reno, NV, USA. http://www.yourownpower.com/Power/grc\%20paper.pdf

McKee, R. A. 2009. Bureau of Land Management (BLM) - Utah State Office - Oil,Gas \& Geothermal Operations. Personal Communications, October 10, 2009.

McKenna, Jason R. 2006. U.S. Army Corps Engineer Research \& Development Center. Increasing Electrical Power Capacity for Military Applications. U.S. Army Corps Engineer Research \& Development Center. http://www.smu.edu/geothermal/Oil\&Gas/Mckenna_Army\%20Corps.pdf

MIT-led interdisciplinary panel. 2006. The Future of Geothermal Energy: Impact of Enhanced Geothermal Systems (EGS) on the United States in the 21st Century. DOE, Washington D.C. http://geothermal.inl.gov/publications/future_of_geothermal_energy.pdf

More, W. J., and M. L. Sorensen. 1979. Geologic Map of the Tooele $1^{\circ} X 2^{\circ}$ Quadrangle, Utah. United States Geological Survey, Miscellaneous Investigations Series Map I-1132. http://geology.utah.gov/maps/geomap/1x2/pdf/i-1132.pdf. Accessed November 2009.

Mundorff, J. C. 1970. Major Thermal Springs of Utah. Utah Geology and Mineralogy Survey Water-Resources Bull. 13, 60 p.

NOAA Satellite and Information Center. Thermal Springs National Geophysical Data Center. Thermal Springs of the United States. http://map.ngdc.noaa.gov/website/seg/hot_springs/viewer.htm 
Office of Energy Efficiency and Renewable Energy (EERE). 2005. Appendix F - GPRA05 Geothermal Technologies Program Documentation. Projected Benefits of Federal Energy Efficiency and Renewable Energy Programs (FY 2005-FY 2050), Washington D.C.

http://www1.eere.energy.gov/ba/pdfs/gpra_fy05_appendix_f.pdf

Peltier, R. 2007. Raft River Geothermal Project, Malto, Idaho. Power: Business and Technology for the Global Generation Industry.

http://www.powermag.com/renewables/geothermal/Raft-River-Geothermal-Project-MaltaIdaho_231.html

Petty, Susan. 2007. Engineering Geothermal Systems in Oil \& Gas Reservoirs. Presentation at the Southern Methodist University (SMU) Geothermal Lab conference on Geothermal Energy Utilization Associated with Oil and Gas Development. June 12 and 13, 2007.

http://www.smu.edu/geothermal/Oil\&Gas/2007/Petty_Susan\%20Engineering\%20Geothermal\%20Sy stems\%20in\%20Reservoirs.pdf

Rafferty, Kevin. 2000. Geothermal Power Generation: A Primer on Low-temperature, Small-scale Applications. Geo-Heat Center. http://geoheat.oit.edu/pdf/powergen.pdf

Shibaki, Masashi. 2003. Geothermal Energy for Electric Power. A Renewable Energy Policy Project (REPP) Issue Brief. December 2003.

http://www.crest.org/articles/static/1/binaries/Geothermal_Issue_Brief.pdf

Southern Methodist University (SMU) Geothermal Lab. 2004. Geothermal Map of the United States (heat flow map).

http://www.smu.edu/geothermal/heatflow/geothermal_all_us_clipped_150dpi_pagesize_legend.gif

United States Department of Interior Bureau of Land Management (BLM). 2008. Geothermal Leasing in the Fish Lake National Forest, Cedar City and Fillmore BLM Field Offices.

Environmental Assessment UT-010-08-051.

http://www.blm.gov/pgdata/etc/medialib/blm/ut/lands_and_minerals/geothermal/geothermal_sal es.Par.16077.File.dat/December\%20geothermal\%20EA[1].pdf

Utah Geothermal Working Group (UGWG). 2005. Geothermal Energy Development in Utah. A position paper by the Utah Geothermal Working Group.

http://geology.utah.gov/emp/geothermal/ugwg/pdf/ugwg_paper0405.pdf

WGA (Western Governors Association) Geothermal Task Force. 2005. Near-Term Geothermal Resource Assessment. WGA. http://www.geo-

energy.org/information/developing/WGA\%20GEOTHERMAL\%20TASK\%20FORCE\%20RESOUR CE\%20ASSESSMENT\%20NOV\%203\%2020051.pdf 


\section{C-12}

ving Ground, UT

Pacific Northwest National Laboratory, May 2010 


\section{APPENDIX D}

Analysis of Ground Source Heat Pump Opportunities 
Renewable Energy Opportunities at Dugway Proving Ground, UT Pacific Northwest National Laboratory, May 2010 


\section{Appendix D: Analysis of Ground Source Heat Pump Opportunities}

Ground source heat pumps (GSHPs) use the stable temperatures of the earth and groundwater to improve the coefficient of performance of heating and cooling applications for buildings. Common GSHP configurations include open-loop, horizontal closed-loop, and vertical closed-loop.

- Open-loop systems use open wells or bodies of water as direct heat transfer mediums to provide cool temperatures in the summer and warm temperatures in the winter. Heat transfer is only needed once, at the building, because groundwater is used directly, and the limited drilling and trenching results in a lower first cost.

- Closed-loop systems use heat transfer fluid inside a sealed pipe to exchange heat with the earth. Closed-loop systems have lower pumping requirements and are more efficient than open-loop systems. However, soil type and moisture content is more critical to the performance of these systems, and the trenching and drilling significantly increases first cost. Horizontal loops require trenching, so that all the piping lies at the same depth in the ground.

- Vertical closed-loop GSHPs are deployed in vertical boreholes, and are the most efficient configuration.

GSHPs are applicable in almost any building with both heating and cooling. They can be used in buildings as small as 100 square feet, or up to 1 million square feet. Multiple GSHPs can be used in a single building to meet the load, or the same ground loop can be shared between buildings.

To install GSHPs at a building, the surrounding area will have certain prerequisites, depending on the type of GSHP. Open-loop GSHPs need a water source and sink. The source can be a well or open body of water. To discharge this water, the sink can be a secondary well, the open body of water used as the source, another body of water, or a storm drain. Water volume requirements depend on the size of GSHP installed, but typically between 1.5 and 3.0 gallons per minute are needed per cooling ton. This greatly affects the feasibility of open-loop systems in some areas, as do local codes and regulations. Many locations do not want to risk groundwater depletion or contamination.

Horizontal closed-loop GSHPs have a different limiting factor: sufficient land area. The heat transfer for these systems occurs in pipes laid in trenches that are between 100 and 400 feet long per cooling ton, spaced between 6 and 12 feet apart. The soil characteristics and number of pipes per trench determine the pipe length; more pipes (up to six) per trench save land space but require more piping.

Where significant land area or water volumes are not available, vertical closed-loop GSHPs may be the only option. In these systems, the heat transfer pipes are placed vertically in the ground, at depths of between 75 and 300 feet. Some land area is still required, because the pipe wells need to be spaced at least 15 to 20 feet apart, and 200 to 600 feet of piping are needed per cooling ton.

\section{Ground Source Heat Pump Analysis Approach}

For the purposes of this assessment, GSHPs were evaluated using the data from the 2009 Facility Energy Decision System (FEDS) assessment for Dugway Proving Ground. Open-loop, horizontal closed-loop, and vertical closed-loop configurations were analyzed for all buildings included in that assessment. 
The FEDS building energy model was used to develop a representation of Dugway Proving Ground based upon a 2009 PNNL data-gathering trip. Based on these results, site judgment can be used to determine cost-effectiveness of retrofitting the newer buildings. This approach provides a reliable first cut to determine whether GSHPs might be economically feasible. It narrows the range of possibilities for potential projects, resulting in a list of building types that are worthwhile to investigate in more detail.

Site-specific TMY (typical meteorological year) weather data and soil/ground characteristics were used in the analysis, along with Dugway Proving Ground's current energy prices. The weather data used for this analysis came from the Salt Lake City International Airport and the following soil characteristics values were used in the calculations:

- Soil thermal diffusivity: 0.02

- Overburden depth: $100 \mathrm{ft}$

- Bedrock thermal conductivity: $1.4 \mathrm{Btu} /\left(\mathrm{hr} \cdot \mathrm{ft} \cdot{ }^{\circ} \mathrm{F}\right)$

The values are sufficient to provide an initial screening tool for potential projects, but actual testing to evaluate soil characteristics will be necessary before actual project costs and returns can be determined.

Building data were entered for groups of similar buildings, based on age, size, and use type. Table D1 shows the general characteristics of buildings in each group and Table D-2 shows which buildings are in each group (groups in which no buildings were found to be economic candidates for GSHPs have been left off of Table D-2 for brevity). This model was updated with current fuel, equipment, and labor prices, and fuel use information to determine cost-effectiveness for GSHPs across the site. Site-specific TMY weather data and soil/ground characteristics typical for the area were used in the analysis. However, detailed soil testing of a specific site is necessary before actual project costs can be determined. The model does not consider site limitations like land area or water source availability (for closed and open loops, respectively). The assumption is that there are sufficient thermal sources/sinks in place. 
Table D-1: Building Groups Analyzed in FEDS for GSHPs

\begin{tabular}{|c|c|c|c|c|c|}
\hline \multirow[b]{2}{*}{$\begin{array}{c}\text { Group } \\
\text { ID }\end{array}$} & \multicolumn{4}{|c|}{ Building Group Description } & \multirow[b]{2}{*}{$\begin{array}{l}\text { Example } \\
\text { Building }\end{array}$} \\
\hline & Use Type & $\begin{array}{l}\text { Average } \\
\text { Size (sf) }\end{array}$ & $\begin{array}{l}\text { Average } \\
\text { Vintage }\end{array}$ & $\begin{array}{c}\text { Number of } \\
\text { Buildings } \\
\text { Represented }\end{array}$ & \\
\hline 1a & Overhead Protection & 4,118 & 1988 & 10 & 5143 \\
\hline $1 \mathrm{~b}$ & Enclosed Shelter & 642 & 1980 & 35 & 5951 \\
\hline $10 \mathrm{~b}$ & 1952 Large Administration & 55,848 & 1952 & 1 & 5330 \\
\hline $10 \mathrm{c}$ & Child Development Centers & 57,162 & 1973 & 2 & 5124 \\
\hline 10d & 1990s Medium Administration & 20,955 & 1991 & 2 & 4531 \\
\hline $10 \mathrm{e}$ & 1950s Medium Administration & 17,978 & 1952 & 5 & 1010 \\
\hline $10 f$ & Small Administration and Facility Support & 1,753 & 1970 & 18 & 4161 \\
\hline 21a & Small Health Clinic & 7,879 & 1965 & 2 & 5116 \\
\hline $21 \mathrm{~b}$ & 1952 Large Clinic & 34,637 & 1952 & 1 & 5236 \\
\hline $23 a$ & 1940-60s Electronics and Communications & 2,068 & 1959 & 23 & 4258 \\
\hline $23 \mathrm{~b}$ & 1980-00s Electronics and Communications & 1,483 & 1992 & 26 & 7353 \\
\hline $30 \mathrm{a}$ & 1950s Medium/Large Barracks & 28,502 & 1952 & 2 & 5140 \\
\hline $30 \mathrm{~b}$ & 1950s Medium Barracks & 16,050 & 1952 & 3 & 5220 \\
\hline $30 \mathrm{c}$ & East Wherry, Single Unit, No Renovation & 1,365 & 1959 & 25 & 20 \\
\hline 30d & East Wherry, Multi Unit, No Renovation & 3,907 & 1959 & 12 & 60 \\
\hline $30 \mathrm{e}$ & East Wherry, Single Unit, Phase I & 1,620 & 1959 & 29 & 180 \\
\hline $30 f$ & East Wherry, Multi Unit, Phase I & 3,293 & 1959 & 21 & 201 \\
\hline $30 \mathrm{~g}$ & East Wherry, Single Unit, Phase II & 1,410 & 1959 & 14 & 111 \\
\hline $30 \mathrm{~h}$ & East Wherry, Multi Unit, Phase II & 3,283 & 1959 & 22 & 100 \\
\hline $30 \mathrm{i}$ & Mountain View Housing & 3,649 & 1987 & 53 & 5540 \\
\hline $30 \mathrm{j}$ & St John Park & 2,465 & 1964 & 22 & 5377 \\
\hline 301 & West Wherry, Single Unit, No Renovation & 1,670 & 1959 & 41 & 310 \\
\hline $30 \mathrm{~m}$ & West Wherry, Multi Unit, No Renovation & 3,427 & 1959 & 41 & 300 \\
\hline $30 n$ & Hotel/Guesthouse & 19,033 & 1993 & 3 & 5228 \\
\hline $40 \mathrm{a}$ & 1950s Conditioned Storage & 1,806 & 1952 & 16 & 4235 \\
\hline 40b & 1980s Conditioned Storage & 1,247 & 1984 & 14 & 3158 \\
\hline $40 c$ & Unconditioned Storage & 1,159 & 1976 & 50 & 3643 \\
\hline $50 \mathrm{a}$ & Utility Buildings & 661 & 1959 & 36 & 7153 \\
\hline $50 \mathrm{~b}$ & 1950’s Medium Maintenance Facility & 11,731 & 1952 & 5 & 5474 \\
\hline $50 d$ & $\begin{array}{l}\text { Laboratory Building - Life Sciences \& } \\
\text { Others }\end{array}$ & 35,820 & 1979 & 3 & 4156 \\
\hline $50 \mathrm{~d}-2$ & Materials Test Facility & 25,410 & 1991 & 1 & 8027 \\
\hline $50 \mathrm{e}$ & 1990s Small Laboratory & 4,915 & 1993 & 4 & 7948 \\
\hline $50 f$ & 1950-60s Small Laboratory & 8,819 & 1958 & 6 & 4165 \\
\hline $50 \mathrm{~g}$ & 1950s Small Maintenance Facility & 2,844 & 1953 & 7 & 1006 \\
\hline $50 \mathrm{~h}$ & 1940-50s Large Maintenance Facility & 27,103 & 1951 & 3 & 5470 \\
\hline $50 \mathrm{i}$ & 1980-90s Small Maintenance Facility & 4,094 & 1990 & 11 & 4119 \\
\hline $50 \mathrm{j}$ & 1980s Medium Maintenance Facility & 10,150 & 1984 & 1 & 1012 \\
\hline $60 \mathrm{a}$ & Dining Facility & 8,296 & 1969 & 2 & 5230 \\
\hline $60 \mathrm{c}$ & Security Facility & 6,683 & 1976 & 5 & 4026 \\
\hline $80 \mathrm{a}$ & Limited use Training Building & 3,382 & 1999 & 10 & 4126 \\
\hline $80 \mathrm{~b}$ & Miscellaneous Recreation & 4,776 & 1957 & 13 & 5126 \\
\hline $80 c$ & Large Physical Fitness Center & 31,938 & 1994 & 1 & 5109 \\
\hline $80 c-2$ & Small Physical Fitness Centers & 5,534 & 1988 & 3 & 4168 \\
\hline
\end{tabular}


Table D-2: Buildings Analyzed in FEDS for GSHPs*

\begin{tabular}{|c|c|c|}
\hline $\begin{array}{c}\text { Group } \\
\text { ID }\end{array}$ & Use Type & Building Numbers \\
\hline $10 \mathrm{~b}$ & 1952 Large Administration & 5330 \\
\hline 10c & Child Development Centers & 5111,5124 \\
\hline 10d & 1990s Medium Administration & $1080,4223,4531$ \\
\hline $10 \mathrm{e}$ & 1950s Medium Administration & 4146, 4239, 5240, 1010, 5450 \\
\hline $10 f$ & Small Administration and Facility Support & $\begin{array}{l}\text { 4038, 5900, 5468, 3034, 5454, 5031, 5807, 1060, 3442, } \\
\text { 4161, 3640, 3038, 8029, 5125, 10001, 4543, 4542, 4034, } \\
\text { 2070, } 5785\end{array}$ \\
\hline $21 \mathrm{a}$ & Small Health Clinic & 4541,5116 \\
\hline $23 a$ & 1940-60s Electronics and Communications & $\begin{array}{l}\text { 3041, 4132, 5444, 4258, 6785, 4016, 3236, 8231, 8148, } \\
\text { 8673, 8117, 8118, 8227, 8225, 8221, 9305, 9302, 8010, } \\
8110,8141,8254,8363,8336\end{array}$ \\
\hline $30 \mathrm{a}$ & 1950s Medium/Large Barracks & 5132,5140 \\
\hline $30 \mathrm{i}$ & Mountain View Housing & All Mountain View Housing \\
\hline $30 \mathrm{j}$ & St John Park & St John Park Housing, Renovated \\
\hline $30 n$ & Hotel/Guesthouse & 5226, 5233, 5228 \\
\hline $40 \mathrm{a}$ & 1950s Conditioned Storage & $\begin{array}{l}\text { 5464, 4502, 4235, 5716, 5476, 5462, 5466, 2022, 2023, } \\
4438,4439,4448,4449,4443,3439,3259,5668\end{array}$ \\
\hline $50 \mathrm{a}$ & Utility Buildings & $\begin{array}{l}\text { 0521A, 4163, 7143, 7354, 9424, 7351, 9322, 7153, 4023, } \\
\text { 4224, 4313, 5980, 6786, 4594, 8024, 3258, 6654, 5985, } \\
\text { 6553, 5526, 0802A, 5294, 4109, 4511, 4227, 4053, 6813, } \\
6613,6711,3143,4105,5110,5214,9420,5340,9406\end{array}$ \\
\hline $50 \mathrm{~b}$ & 1950s Medium Maintenance Facility & $4335,5030,5460,5474,5658$ \\
\hline $50 \mathrm{~d}$ & $\begin{array}{l}\text { Laboratory Building - Life Sciences \& } \\
\text { Others }\end{array}$ & 2028, 2029, 4156 \\
\hline 50d (2) & Materials Test Facility & 8027 \\
\hline $50 \mathrm{e}$ & 1990s Small Laboratory & $8223,7948,8035,8046$ \\
\hline $50 \mathrm{f}$ & 1950-60s Small Laboratory & 2032, 2048, 4153, 4165, 3445, 3043 \\
\hline $60 \mathrm{c}$ & Security Facility & 4026, 5212, 4015, 5438, 4515 \\
\hline $80 \mathrm{a}$ & Limited Use Training Building & $\begin{array}{l}\text { 0745C, 9300, 0745H, 0745A, 0745B, 0745E, 0745D, 0745F, } \\
\text { 4122, 4126 }\end{array}$ \\
\hline $80 \mathrm{c}$ & Large Physical Fitness Centers & 5109 \\
\hline $80 c(2)$ & Small Physical Fitness Centers & $3641,4551,4168$ \\
\hline
\end{tabular}

* Building groups with no economically feasible projects are not included in this list

\section{Ground Source Heat Pump Resource Characterization}

GSHP assessments using FEDS have been completed at many sites in the past using the same analytic approach. The results developed here agree with previous findings. In general, conditions favoring replacement of existing heating and cooling systems with GSHPs include:

- Replacing old equipment. Equipment at the end of its useful life that will soon be replaced provides further economic incentive for GSHP installations, particularly if existing ductwork can be reused.

- More extreme climates. Cold winters, hot summers, or large daily temperature swings allow GSHPs to operate more efficiently than other electric cooling and heating systems. The cost of heating operation is comparable to non-electric heating systems. 
- High cost of non-electric fuels. If electricity is less than approximately 3.5 times as expensive per Btu than other fuels, GSHPs will generally be cost-effective. If no other fuel option is available and electric costs are high, GSHPs will be less expensive to operate than air-source heat pumps.

GSHPs are often not cost-effective in a building that:

- Does not have both cooling and heating. A building needs to be heated and cooled to take advantage of the GSHP efficiency in both modes. However, most of the savings are realized in the heating mode, so buildings with no cooling can still benefit from GSHPs.

- Does not currently have ductwork. Installing a new air distribution system in addition to the conditioning equipment generally adds too much cost for a GSHP retrofit, unless the building is modified to allow zone level heat pumps to be used in conjunction with a water loop connecting the terminal units to a shared ground loop.

- Is newer. Newer buildings (less than about 4 years old) generally have fairly efficient equipment (or at least the performance has not yet degraded significantly). As a result, premature replacement with a GSHP is generally uneconomic. In addition, the building envelope tends to be better, lengthening payback duration.

- Is located in a mild climate. An air-source heat pump has many of the benefits of a GSHP except in extreme temperature conditions. These extreme temperature conditions often are not sufficient to justify replacement.

- Uses an air-source heat pump. An air-source heat pump has many of the benefits of a GSHP except in extreme temperature conditions. These extreme temperature conditions often are not enough to justify replacement.

- Is connected to a central energy plant (unless the CEP will be abandoned). Although central energy systems are often considered to be large energy wasters, on a building-bybuilding basis (that does not account for distribution losses), it is difficult to justify replacement. Centralized chiller plants can use larger, more efficient water-cooled units and can stage several chillers to run closer to full load (which is the most efficient mode).

\section{Ground Source Heat Pumps: Economic and Other Analysis Parameters}

FEDS allows two primary financing options: appropriated funding (using Energy Conservation Investment Program, ECIP, funds) and alternative financing (utility energy services contract (UESC) or energy saving performance contract (ESPC)). The parameters for alternative financing can be adjusted to match the options available to the site. For this assessment, a project life of 25 years and a third-party interest rate of $5 \%$ were used.

FEDS uses the site electric rate schedule and energy costs to determine fuel costs and savings for GSHP retrofits. The entire rate schedule is entered into the modeling software so that consumption and demand can be calculated on a time-of-use basis. At Dugway Proving Ground, electricity is charged according to the following energy rates:

- On-Peak: 2.83\$/kWh (8.29 \$/MMBtu), \$9.45/kW demand

- Off-Peak: 2.36 $/ \mathrm{kWh}$ (6.92 \$/MMBtu), \$1.79/kW demand 
Peak and off-peak times were considered as follows:

Summer (May $1^{\text {st }}$ to September $30^{\text {th }}$ )

o On-Peak: 1300 to 2100

o Off-Peak: 2100 to 1300

Winter (October $1^{\text {st }}$ to April $30^{\text {th }}$ )

o On-Peak: 0700 to 2300

o Off-Peak: 2300 to 0700

A propane cost of 25.73 \$/MMBtu and fuel oil cost of 2.7 \$/gallon (19.47 \$/MMBtu) were used for this analysis. These numbers are based on historical data for Dugway Proving Ground and were obtained from the Army Energy and Water Reporting System (AEWRS). Lastly, ground sourced heat pumps are not an eligible technology to generate RECs.

\section{Findings: Ground Source Heat Pumps}

For a number of situations, ground source heat pumps were preliminarily found to be appropriate for Dugway Proving Ground. These findings (Table D-3) are driven predominantly by the low cost of electricity at Dugway Proving Ground coupled with the relatively high cost of the only available fossil fuel types, propane and fuel oil. Dugway Proving Ground does not have the ideal climate for ground source heat pumps because of the dominance of the heating system. Because of this, it is imperative that individual projects are closely examined to verify that the economics predicted by this preliminary analysis are accurate. This imbalance between heating and cooling loads could be mitigated by selecting large buildings with high internal heat gains.

The simple payback values presented in Table D-3 are the average for all buildings with economic projects within that group. Some of the building groups in Table D-3 contain buildings served by different fuels or with other noteworthy differences. In certain cases, ground source heat pumps were only economic in a small portion of the buildings in a building group. In cases like these, the average payback period was not listed in the tables. To find the economic characteristics for buildings with specific heating and cooling technologies within a group, see Table D-4, which contains the economic results for each building configuration examined. The system costs per square foot for the analysis seen in Table D-3 are as follows:

- Average cost per $\mathrm{ft}^{2}$ for open-loop GSHP systems: $\$ 9.00$

- Average cost per $\mathrm{ft}^{2}$ for horizontal-loop GSHP systems: $\$ 16.00$

- Average cost per $\mathrm{ft}^{2}$ for vertical-loop GSHP systems: $\$ 25.00$

Please note that these costs should be used only as rough reference because heating and cooling loads (on a per square foot basis) can vary drastically between buildings. 
Table D- 3: Simple Payback Period for Building Groups Analyzed in FEDS for GSHPs*

\begin{tabular}{|c|c|c|c|c|c|c|c|}
\hline \multirow{2}{*}{$\begin{array}{c}\text { Group } \\
\text { ID }\end{array}$} & \multirow{2}{*}{ Use Type } & \multicolumn{3}{|c|}{ Alternative Financing } & \multicolumn{3}{|c|}{ Appropriated financing } \\
\hline & & Open & Horz.** & Vert. $\dagger$ & Open & Horz. & Vert. \\
\hline $10 \mathrm{~b}$ & 1952 Large Administration & 5.6 & -- & -- & 4.1 & 12.3 & -- \\
\hline 10c & Child Development Centers & 2.6 & 7.1 & 7.5 & 2.8 & 7.4 & 7.8 \\
\hline $10 \mathrm{~d}$ & 1990’s Medium Administration & 6.2 & -- & -- & 5.6 & 12.1 & -- \\
\hline $10 \mathrm{e}$ & 1950’s Medium Administration & 3.3 & 8.5 & 9.4 & 3.4 & 8.5 & 9.4 \\
\hline $10 \mathrm{f}$ & Small Administration and Facility Support & 8.2 & 10.6 & 11.7 & 7.8 & 9.9 & 11.0 \\
\hline $21 \mathrm{a}$ & Small Health Clinic & 4.3 & 9.5 & 11.2 & 4.3 & 9.1 & 10.7 \\
\hline 23a & 1940-60s Electronics and Communications & 5.1 & 8.3 & 9.6 & 4.2 & 6.7 & 7.7 \\
\hline $30 \mathrm{a}$ & 1950s Medium/Large Barracks & 5.1 & -- & -- & 4.5 & 12.8 & -- \\
\hline $30 \mathrm{i}$ & Mountain View Housing & 8 & 7.3 & 8.8 & 8.4 & 7.6 & 9.1 \\
\hline $30 \mathrm{j}$ & St John Park & 7.9 & 6.7 & 8.9 & 8.7 & 7.2 & 9.6 \\
\hline $30 n$ & Hotel/Guesthouse & 3.5 & 8.6 & 9.7 & 3.4 & 7.9 & 9.0 \\
\hline $40 \mathrm{a}$ & 1950s Conditioned Storage & -- & 14.2 & 14.2 & -- & 13.4 & 13.3 \\
\hline $50 \mathrm{a}$ & Utility Buildings & 10.4 & 7.8 & 9.5 & 12.4 & 7.2 & 11.2 \\
\hline $50 \mathrm{~b}$ & 1950s Medium Maintenance Facility & 6.5 & 9.5 & 11.4 & 6.8 & 10.7 & 11.3 \\
\hline $50 d$ & $\begin{array}{l}\text { Laboratory Building - Life Sciences \& } \\
\text { Others }\end{array}$ & 0.9 & 4.4 & 8.6 & 1.0 & 4.9 & 9.4 \\
\hline $50 d(2)$ & Materials Test Facility & 1.4 & 5.0 & 7.2 & 1.4 & 4.8 & 6.9 \\
\hline $50 \mathrm{e}$ & 1990s Small Laboratory & 8.8 & -- & -- & 10.7 & 14.9 & -- \\
\hline $50 f$ & 1950-60s Small Laboratory & 2.8 & 9.7 & 10 & 2.7 & 8.6 & 9.6 \\
\hline $60 \mathrm{c}$ & Security Facility & 10.2 & 13.5 & -- & 9.5 & 12.8 & -- \\
\hline $80 \mathrm{a}$ & Limited use Training Building & 8.3 & -- & -- & 8.7 & -- & -- \\
\hline $80 c$ & Large Physical Fitness Centers & 3.2 & -- & -- & 3.1 & 8.6 & 11.4 \\
\hline $80 c(2)$ & Small Physical Fitness Centers & 6.7 & 10.1 & 10.8 & 6.7 & 6.2 & 6.7 \\
\hline
\end{tabular}

* Building groups with no economically feasible projects are not included in this list

**Horizontal

$\dagger$ Vertical

Buildings currently served by evaporative coolers were not considered in the analysis. The use of evaporative cooling at Dugway Proving Ground is widespread, especially in smaller buildings. It is possible that individual buildings that use evaporative coolers could be candidates for GSHPs, but because of the relatively short cooling season, buildings with a high demand for non-evaporative cooling should be considered first because they will have superior project economics and impact.

\section{Ground Source Heat Pumps: Next Steps}

The next step will be to look at individual buildings using building-specific data such as:

- $\quad$ Detailed load data, if available

- Current operating efficiencies

- Current system configuration

and detailed site data, including:

- $\quad$ Soil conductivity data (closed loops only)

- Water table depth at location of proposed systems (open loops only) 
- $\quad$ Land availability (closed-loop systems)

- $\quad$ Source and sink availability/regulatory limitations (open loop only)

In addition to pursuing those building types that were preliminarily found to be cost-effective, Dugway Proving Ground should analyze new construction projects, failed heating and cooling equipment, and major renovations to determine if additional opportunities for GSHPs exist. New incentives or changes in energy costs may result in additional cost-effective projects.

Once a more in-depth analysis has identified which specific buildings are suitable for ground source heat pumps, the system can be specified by an experienced designer.

\section{Ground Source Heat Pump Sources of Information}

Federal Technology Alert. "Ground Source Heat Pumps Applied to Federal Facilities - Second Edition.” Federal Energy Management Program. DOE/EE-0245. March 2001.

http://www1.eere.energy.gov/femp/pdfs/FTA_gshp.pdf. 
Table D-4: Detailed GSHP Economic Results

\begin{tabular}{|c|c|c|c|c|c|c|}
\hline $\begin{array}{l}\text { Funding } \\
\text { Source }\end{array}$ & Building Set Description & Current Heating and Cooling Technology & Retrofit Technology & $\begin{array}{l}\text { Payback } \\
\text { Period }\end{array}$ & SIR & $\begin{array}{l}\text { Installed } \\
\text { Capital } \\
\text { Cost }(\$)\end{array}$ \\
\hline Alternative & 1952 Large Administration & $\begin{array}{c}\text { Distillate Oil Conventional Boiler / } \\
\text { Electric water-Cooled Reciprocating } \\
\text { Chiller }\end{array}$ & $\begin{array}{l}\text { Open-Loop Ground-Coupled } \\
\text { Heat Pump System }\end{array}$ & 5.6 & 2.1 & 73465 \\
\hline Appropriated & 1952 Large Administration & $\begin{array}{c}\text { Distillate Oil Conventional Boiler / } \\
\text { Electric Water-Cooled Reciprocating } \\
\text { Chiller }\end{array}$ & $\begin{array}{l}\text { Open-Loop Ground-Coupled } \\
\text { Heat Pump System }\end{array}$ & 4.1 & 3.3 & 85220 \\
\hline Appropriated & 1952 Large Administration & $\begin{array}{c}\text { Distillate Oil Conventional Boiler / } \\
\text { Electric Water-Cooled Reciprocating } \\
\text { Chiller }\end{array}$ & $\begin{array}{c}\text { Horizontal Closed-Loop } \\
\text { Ground-Coupled Heat Pump } \\
\text { System } \\
\end{array}$ & 12.3 & 1.1 & 249133 \\
\hline Alternative & Child Development Centers & $\begin{array}{c}\text { Distillate Oil Conventional Boiler / } \\
\text { Electric Package Unit }\end{array}$ & $\begin{array}{l}\text { Open-Loop Ground-Coupled } \\
\text { Heat Pump System }\end{array}$ & 3.5 & 3.3 & 95505 \\
\hline Alternative & Child Development Centers & $\begin{array}{c}\text { Propane Conventional Boiler / Electric } \\
\text { Package Unit }\end{array}$ & $\begin{array}{l}\text { Open-Loop Ground-Coupled } \\
\text { Heat Pump System }\end{array}$ & 2 & 7.2 & 81356 \\
\hline Appropriated & Child Development Centers & $\begin{array}{c}\text { Distillate Oil Conventional Boiler / } \\
\text { Electric Package Unit }\end{array}$ & $\begin{array}{l}\text { Open-Loop Ground-Coupled } \\
\text { Heat Pump System }\end{array}$ & 3.7 & 3.5 & 110786 \\
\hline Appropriated & Child Development Centers & $\begin{array}{c}\text { Propane Conventional Boiler / Electric } \\
\text { Package Unit }\end{array}$ & $\begin{array}{l}\text { Open-Loop Ground-Coupled } \\
\text { Heat Pump System }\end{array}$ & 2.1 & 6.5 & 94373 \\
\hline Alternative & Child Development Centers & $\begin{array}{c}\text { Distillate oil Conventional Boiler / } \\
\text { Electric Package Unit }\end{array}$ & $\begin{array}{c}\text { Horizontal Closed-Loop } \\
\text { Ground-Coupled Heat Pump } \\
\text { System }\end{array}$ & 9.8 & 1.3 & 256627 \\
\hline Alternative & Child Development Centers & $\begin{array}{c}\text { Propane Conventional Boiler / Electric } \\
\text { Package Unit }\end{array}$ & $\begin{array}{l}\text { Horizontal Closed-Loop } \\
\text { Ground-Coupled Heat Pump } \\
\text { System } \\
\end{array}$ & 5.4 & 2.7 & 218609 \\
\hline Appropriated & Child Development Centers & $\begin{array}{c}\text { Distillate Oil Conventional Boiler / } \\
\text { Electric Package Unit }\end{array}$ & $\begin{array}{c}\text { Horizontal Closed-Loop } \\
\text { Ground-Coupled Heat Pump } \\
\text { System }\end{array}$ & 9.8 & 1.4 & 297688 \\
\hline Appropriated & Child Development Centers & $\begin{array}{c}\text { Propane Conventional Boiler / Electric } \\
\text { Package Unit }\end{array}$ & $\begin{array}{c}\text { Horizontal Closed-Loop } \\
\text { Ground-Coupled Heat Pump } \\
\text { System }\end{array}$ & 5.7 & 2.5 & 253586 \\
\hline Alternative & Child Development Centers & $\begin{array}{c}\text { Distillate Oil Conventional Boiler / } \\
\text { Electric Package Unit }\end{array}$ & $\begin{array}{c}\text { Vertical Closed-Loop } \\
\text { Ground-Coupled Heat Pump } \\
\text { System }\end{array}$ & 10.3 & 1.2 & 277253 \\
\hline Alternative & Child Development Centers & $\begin{array}{c}\text { Propane Conventional Boiler / Electric } \\
\text { Package Unit }\end{array}$ & $\begin{array}{c}\text { Vertical Closed-Loop } \\
\text { Ground-Coupled Heat Pump } \\
\text { System }\end{array}$ & 5.7 & 2.5 & 236179 \\
\hline Appropriated & Child Development Centers & $\begin{array}{c}\text { Distillate Oil Conventional Boiler / } \\
\text { Electric Package Unit }\end{array}$ & $\begin{array}{l}\text { Vertical Closed-Loop } \\
\text { Ground-Coupled Heat Pump } \\
\text { System }\end{array}$ & 10.3 & 1.3 & 321614 \\
\hline Appropriated & Child Development Centers & $\begin{array}{c}\text { Propane Conventional Boiler / Electric } \\
\text { Package Unit }\end{array}$ & $\begin{array}{l}\text { Vertical Closed-Loop } \\
\text { Ground-Coupled Heat Pump } \\
\text { System } \\
\end{array}$ & 6.1 & 2.3 & 273967 \\
\hline Alternative & $\begin{array}{c}\text { 1990s Medium } \\
\text { Administration }\end{array}$ & $\begin{array}{c}\text { Distillate Oil Conventional Boiler / } \\
\text { Electric Package Unit }\end{array}$ & $\begin{array}{c}\text { Open-Loop Ground-Coupled } \\
\text { Heat Pump System }\end{array}$ & 6.2 & 1.9 & 66039 \\
\hline Appropriated & $\begin{array}{c}\text { 1990s Medium } \\
\text { Administration }\end{array}$ & $\begin{array}{c}\text { Distillate Oil Conventional Boiler / } \\
\text { Electric Package Unit }\end{array}$ & $\begin{array}{l}\text { Open-Loop Ground-Coupled } \\
\text { Heat Pump System }\end{array}$ & 5.6 & 2.4 & 76605 \\
\hline
\end{tabular}




\begin{tabular}{|c|c|c|c|c|c|c|}
\hline $\begin{array}{l}\text { Funding } \\
\text { Source }\end{array}$ & Building Set Description & Current Heating and Cooling Technology & Retrofit Technology & $\begin{array}{l}\text { Payback } \\
\text { Period }\end{array}$ & SIR & $\begin{array}{l}\text { Installed } \\
\text { Capital } \\
\text { Cost (\$) }\end{array}$ \\
\hline Appropriated & $\begin{array}{l}\text { 1990s Medium } \\
\text { Administration }\end{array}$ & $\begin{array}{c}\text { Distillate Oil Conventional Boiler / } \\
\text { Electric Package Unit }\end{array}$ & $\begin{array}{l}\text { Horizontal Closed-Loop } \\
\text { Ground-Coupled Heat Pump } \\
\text { System }\end{array}$ & 12.1 & 1.1 & 164746 \\
\hline Alternative & $\begin{array}{l}\text { 1950s Medium } \\
\text { Administration }\end{array}$ & $\begin{array}{c}\text { Propane Conventional Boiler / Electric } \\
\text { Package Unit }\end{array}$ & $\begin{array}{l}\text { Open-Loop Ground-Coupled } \\
\text { Heat Pump System }\end{array}$ & 2.8 & 5.1 & 209093 \\
\hline Appropriated & $\begin{array}{l}\text { 1950s Medium } \\
\text { Administration }\end{array}$ & $\begin{array}{c}\text { Propane Conventional Boiler / Electric } \\
\text { Package Unit }\end{array}$ & $\begin{array}{l}\text { Open-Loop Ground-Coupled } \\
\text { Heat Pump System }\end{array}$ & 3 & 6.1 & 242548 \\
\hline Alternative & $\begin{array}{l}\text { 1950s Medium } \\
\text { Administration }\end{array}$ & $\begin{array}{c}\text { Propane Conventional Boiler / Electric } \\
\text { Package Unit }\end{array}$ & $\begin{array}{c}\text { Horizontal Closed-Loop } \\
\text { Ground-Coupled Heat Pump } \\
\text { System }\end{array}$ & 8.1 & 1.8 & 547061 \\
\hline Appropriated & $\begin{array}{l}\text { 1950s Medium } \\
\text { Administration }\end{array}$ & $\begin{array}{c}\text { Propane Conventional Boiler / Electric } \\
\text { Package Unit }\end{array}$ & $\begin{array}{c}\text { Horizontal Closed-Loop } \\
\text { Ground-Coupled Heat Pump } \\
\text { System }\end{array}$ & 8.1 & 2.3 & 634590 \\
\hline Alternative & $\begin{array}{l}\text { 1950s Medium } \\
\text { Administration }\end{array}$ & $\begin{array}{c}\text { Propane Conventional Boiler / Electric } \\
\text { Package Unit }\end{array}$ & $\begin{array}{c}\text { Vertical Closed-Loop } \\
\text { Ground-Coupled Heat Pump } \\
\text { System }\end{array}$ & 8.7 & 1.7 & 611231 \\
\hline Appropriated & $\begin{array}{l}\text { 1950s Medium } \\
\text { Administration }\end{array}$ & $\begin{array}{c}\text { Propane Conventional Boiler / Electric } \\
\text { Package Unit }\end{array}$ & $\begin{array}{c}\text { Vertical Closed-Loop } \\
\text { Ground-Coupled Heat Pump } \\
\text { System }\end{array}$ & 8.8 & 2 & 709028 \\
\hline Alternative & Building 5450, 0ld wing & $\begin{array}{c}\text { Propane Conventional Boiler / Electric } \\
\text { Package Unit }\end{array}$ & $\begin{array}{c}\text { Horizontal Closed-Loop } \\
\text { Ground-Coupled Heat Pump } \\
\text { System }\end{array}$ & 11.5 & 1.2 & 122421 \\
\hline Appropriated & Building 5450, 0ld wing & $\begin{array}{c}\text { Propane Conventional Boiler / Electric } \\
\text { Package Unit }\end{array}$ & $\begin{array}{c}\text { Horizontal Closed-Loop } \\
\text { Ground-Coupled Heat Pump } \\
\text { System }\end{array}$ & 11.4 & 1.5 & 142008 \\
\hline Appropriated & Building 5450, Old wing & $\begin{array}{c}\text { Propane Conventional Boiler / Electric } \\
\text { Package Unit }\end{array}$ & $\begin{array}{c}\text { Vertical Closed-Loop } \\
\text { Ground-Coupled Heat Pump } \\
\text { System }\end{array}$ & 13.3 & 1.3 & 171022 \\
\hline Alternative & Building 5450, 0ld wing & $\begin{array}{c}\text { Propane Conventional Boiler / Electric } \\
\text { Package Unit }\end{array}$ & $\begin{array}{l}\text { Open-Loop Ground-Coupled } \\
\text { Heat Pump System }\end{array}$ & 4.3 & 3.3 & 47531 \\
\hline Appropriated & Building 5450, old wing & $\begin{array}{c}\text { Propane Conventional Boiler / Electric } \\
\text { Package Unit }\end{array}$ & $\begin{array}{l}\text { Open-Loop Ground-Coupled } \\
\text { Heat Pump System }\end{array}$ & 4.4 & 3.9 & 55135 \\
\hline Alternative & Building 5450, Old wing & $\begin{array}{c}\text { Propane Conventional Boiler / Electric } \\
\text { Package Unit }\end{array}$ & $\begin{array}{l}\text { Vertical Closed-Loop } \\
\text { Ground-Coupled Heat Pump } \\
\text { System }\end{array}$ & 13.4 & 1.1 & 147433 \\
\hline Alternative & Building 5450, New wing & $\begin{array}{c}\text { Propane Conventional Boiler / Electric } \\
\text { Package Unit }\end{array}$ & $\begin{array}{l}\text { Open-Loop Ground-Coupled } \\
\text { Heat Pump System }\end{array}$ & 8.8 & 1.5 & 33491 \\
\hline Appropriated & Building 5450, New wing & $\begin{array}{c}\text { Propane Conventional Boiler / Electric } \\
\text { Package Unit }\end{array}$ & $\begin{array}{l}\text { Open-Loop Ground-Coupled } \\
\text { Heat Pump System }\end{array}$ & 8.5 & 2 & 38849 \\
\hline Alternative & $\begin{array}{l}\text { Small Administration and } \\
\text { Facility Support } \\
\end{array}$ & $\begin{array}{c}\text { Propane Conventional Furnace / Electric } \\
\text { Package Unit }\end{array}$ & $\begin{array}{l}\text { Open-Loop Ground-Coupled } \\
\text { Heat Pump System }\end{array}$ & 7.4 & 2 & 115299 \\
\hline Alternative & $\begin{array}{l}\text { Small Administration and } \\
\text { Facility Support }\end{array}$ & $\begin{array}{c}\text { Distillate Oil Conventional Furnace / } \\
\text { Electric Package Unit }\end{array}$ & $\begin{array}{l}\text { Open-Loop Ground-Coupled } \\
\text { Heat Pump System }\end{array}$ & 9.6 & 1.3 & 84957 \\
\hline Appropriated & $\begin{array}{l}\text { Small Administration and } \\
\text { Facility Support }\end{array}$ & $\begin{array}{c}\text { Propane Conventional Furnace / Electric } \\
\text { Package Unit }\end{array}$ & $\begin{array}{l}\text { Open-Loop Ground-Coupled } \\
\text { Heat Pump System }\end{array}$ & 7.8 & 1.5 & 133747 \\
\hline Alternative & $\begin{array}{l}\text { Small Administration and } \\
\text { Facility Support }\end{array}$ & $\begin{array}{c}\text { Propane Conventional Furnace / Electric } \\
\text { Package Unit }\end{array}$ & $\begin{array}{l}\text { Horizontal Closed-Loop } \\
\text { Ground-Coupled Heat Pump } \\
\text { System }\end{array}$ & 9.6 & 1.5 & 156233 \\
\hline Alternative & $\begin{array}{l}\text { Small Administration and } \\
\text { Facility Support }\end{array}$ & $\begin{array}{c}\text { Distillate Oil Conventional Furnace / } \\
\text { Electric Package Unit }\end{array}$ & $\begin{array}{l}\text { Horizontal Closed-Loop } \\
\text { Ground-Coupled Heat Pump }\end{array}$ & 12.4 & 1 & 115119 \\
\hline
\end{tabular}




\begin{tabular}{|c|c|c|c|c|c|c|}
\hline $\begin{array}{l}\text { Funding } \\
\text { Source }\end{array}$ & Building Set Description & Current Heating and Cooling Technology & Retrofit Technology & $\begin{array}{l}\text { Payback } \\
\text { Period }\end{array}$ & SIR & $\begin{array}{l}\text { Installed } \\
\text { Capital } \\
\text { Cost }(\$)\end{array}$ \\
\hline & & & System & & & \\
\hline Appropriated & $\begin{array}{l}\text { Small Administration and } \\
\text { Facility Support }\end{array}$ & $\begin{array}{c}\text { Propane Conventional Furnace / Electric } \\
\text { Package Unit }\end{array}$ & $\begin{array}{l}\text { Horizontal Closed-Loop } \\
\text { Ground-Coupled Heat Pump } \\
\text { System }\end{array}$ & 9.9 & 1.2 & 181231 \\
\hline Alternative & $\begin{array}{l}\text { Small Administration and } \\
\text { Facility Support }\end{array}$ & $\begin{array}{c}\text { Propane Conventional Furnace / Electric } \\
\text { Package Unit }\end{array}$ & $\begin{array}{c}\text { Vertical Closed-Loop } \\
\text { Ground-Coupled Heat Pump } \\
\text { System }\end{array}$ & 10.6 & 1.4 & 175392 \\
\hline Appropriated & $\begin{array}{l}\text { Small Administration and } \\
\text { Facility Support }\end{array}$ & $\begin{array}{c}\text { Propane Conventional Furnace / Electric } \\
\text { Package Unit }\end{array}$ & $\begin{array}{l}\text { Vertical Closed-Loop } \\
\text { Ground-Coupled Heat Pump } \\
\text { System }\end{array}$ & 11 & 1.1 & 203454 \\
\hline Alternative & Small Health Clinic & $\begin{array}{c}\text { Propane Conventional Furnace / Electric } \\
\text { Package Unit }\end{array}$ & $\begin{array}{l}\text { Open-Loop Ground-Coupled } \\
\text { Heat Pump System }\end{array}$ & 4.3 & 3.3 & 65416 \\
\hline Appropriated & Small Health Clinic & $\begin{array}{c}\text { Propane Conventional Furnace / Electric } \\
\text { Package Unit }\end{array}$ & $\begin{array}{l}\text { Open-Loop Ground-Coupled } \\
\text { Heat Pump System }\end{array}$ & 4.3 & 4.2 & 75883 \\
\hline Alternative & Small Health Clinic & $\begin{array}{c}\text { Propane Conventional Furnace / Electric } \\
\text { Package Unit }\end{array}$ & $\begin{array}{l}\text { Horizontal Closed-Loop } \\
\text { Ground-Coupled Heat Pump } \\
\text { System }\end{array}$ & 9.5 & 1.5 & 139165 \\
\hline Appropriated & Small Health Clinic & $\begin{array}{c}\text { Propane Conventional Furnace / Electric } \\
\text { Package Unit }\end{array}$ & $\begin{array}{c}\text { Horizontal Closed-Loop } \\
\text { Ground-Coupled Heat Pump } \\
\text { System }\end{array}$ & 9.1 & 2 & 161431 \\
\hline Alternative & Small Health Clinic & $\begin{array}{c}\text { Propane Conventional Furnace / Electric } \\
\text { Package Unit }\end{array}$ & $\begin{array}{l}\text { Vertical Closed-Loop } \\
\text { Ground-Coupled Heat Pump } \\
\text { System }\end{array}$ & 11.2 & 1.3 & 167735 \\
\hline Appropriated & Small Health Clinic & $\begin{array}{c}\text { Propane Conventional Furnace / Electric } \\
\text { Package Unit }\end{array}$ & $\begin{array}{l}\text { Vertical Closed-Loop } \\
\text { Ground-Coupled Heat Pump } \\
\text { System }\end{array}$ & 10.7 & 1.7 & 194573 \\
\hline Alternative & $\begin{array}{l}\text { 1940-60s Electronics and } \\
\text { Communications }\end{array}$ & $\begin{array}{c}\text { Distillate Oil Conventional Boiler / } \\
\text { Electric Package Unit }\end{array}$ & $\begin{array}{l}\text { Open-Loop Ground-Coupled } \\
\text { Heat Pump System }\end{array}$ & 5.9 & 2.1 & 344008 \\
\hline Alternative & $\begin{array}{l}\text { 1940-60s Electronics and } \\
\text { Communications }\end{array}$ & $\begin{array}{c}\text { Propane Conventional Boiler / Electric } \\
\text { Air-Cooled Chiller }\end{array}$ & $\begin{array}{l}\text { Open-Loop Ground-Coupled } \\
\text { Heat Pump System }\end{array}$ & 4.2 & 3.5 & 229339 \\
\hline Appropriated & $\begin{array}{l}\text { 1940-60s Electronics and } \\
\text { Communications }\end{array}$ & $\begin{array}{c}\text { Distillate Oil Conventional Boiler / } \\
\text { Electric Package Unit }\end{array}$ & $\begin{array}{l}\text { Open-Loop Ground-Coupled } \\
\text { Heat Pump System }\end{array}$ & 4.4 & 3.1 & 399050 \\
\hline Appropriated & $\begin{array}{l}\text { 1940-60s Electronics and } \\
\text { Communications }\end{array}$ & $\begin{array}{c}\text { Propane Conventional Boiler / Electric } \\
\text { Air-Cooled Chiller }\end{array}$ & $\begin{array}{l}\text { Open-Loop Ground-Coupled } \\
\text { Heat Pump System }\end{array}$ & 4 & 4.4 & 266033 \\
\hline Alternative & $\begin{array}{l}\text { 1940-60s Electronics and } \\
\text { Communications }\end{array}$ & $\begin{array}{c}\text { Distillate Oil Conventional Boiler / } \\
\text { Electric Package Unit }\end{array}$ & $\begin{array}{c}\text { Horizontal Closed-Loop } \\
\text { Ground-Coupled Heat Pump } \\
\text { System }\end{array}$ & 9.7 & 1.3 & 535663 \\
\hline Alternative & $\begin{array}{l}\text { 1940-60s Electronics and } \\
\text { Communications }\end{array}$ & $\begin{array}{l}\text { Propane Conventional Boiler / Electric } \\
\text { Air-Cooled Chiller }\end{array}$ & $\begin{array}{l}\text { Horizontal Closed-Loop } \\
\text { Ground-Coupled Heat Pump } \\
\text { System }\end{array}$ & 6.9 & 2.2 & 357109 \\
\hline Appropriated & $\begin{array}{l}\text { 1940-60s Electronics and } \\
\text { Communications }\end{array}$ & $\begin{array}{c}\text { Distillate Oil Conventional Boiler / } \\
\text { Electric Package Unit }\end{array}$ & $\begin{array}{l}\text { Horizontal Closed-Loop } \\
\text { Ground-Coupled Heat Pump } \\
\text { System }\end{array}$ & 7 & 2 & 621369 \\
\hline Appropriated & $\begin{array}{l}\text { 1940-60s Electronics and } \\
\text { Communications }\end{array}$ & $\begin{array}{l}\text { Propane Conventional Boiler / Electric } \\
\text { Air-Cooled Chiller }\end{array}$ & $\begin{array}{c}\text { Horizontal Closed-Loop } \\
\text { Ground-Coupled Heat Pump } \\
\text { System }\end{array}$ & 6.3 & 2.8 & 414246 \\
\hline Alternative & $\begin{array}{l}\text { 1940-60s Electronics and } \\
\text { Communications }\end{array}$ & $\begin{array}{c}\text { Distillate Oil Conventional Boiler / } \\
\text { Electric Package Unit }\end{array}$ & $\begin{array}{l}\text { Vertical Closed-Loop } \\
\text { Ground-Coupled Heat Pump } \\
\text { System }\end{array}$ & 11.1 & 1.1 & 634672 \\
\hline Alternative & $\begin{array}{l}\text { 1940-60s Electronics and } \\
\text { Communications }\end{array}$ & $\begin{array}{c}\text { Propane Conventional Boiler / Electric } \\
\text { Air-Cooled Chiller }\end{array}$ & $\begin{array}{l}\text { Vertical Closed-Loop } \\
\text { Ground-Coupled Heat Pump }\end{array}$ & 8 & 1.9 & 423114 \\
\hline
\end{tabular}




\begin{tabular}{|c|c|c|c|c|c|c|}
\hline $\begin{array}{l}\text { Funding } \\
\text { Source }\end{array}$ & Building Set Description & Current Heating and Cooling Technology & Retrofit Technology & $\begin{array}{l}\text { Payback } \\
\text { Period }\end{array}$ & SIR & $\begin{array}{l}\text { Installed } \\
\text { Capital } \\
\text { Cost }(\$)\end{array}$ \\
\hline & & & System & & & \\
\hline Appropriated & $\begin{array}{l}\text { 1940-60s Electronics and } \\
\text { Communications }\end{array}$ & $\begin{array}{c}\text { Distillate Oil Conventional Boiler / } \\
\text { Electric Package Unit }\end{array}$ & $\begin{array}{c}\text { Vertical Closed-Loop } \\
\text { Ground-Coupled Heat Pump } \\
\text { System }\end{array}$ & 8.1 & 1.7 & 736219 \\
\hline Appropriated & $\begin{array}{l}\text { 1940-60s Electronics and } \\
\text { Communications }\end{array}$ & $\begin{array}{c}\text { Propane Conventional Boiler / Electric } \\
\text { Air-Cooled Chiller }\end{array}$ & $\begin{array}{l}\text { Vertical Closed-Loop } \\
\text { Ground-Coupled Heat Pump } \\
\text { System }\end{array}$ & 7.3 & 2.4 & 490813 \\
\hline Alternative & $\begin{array}{l}\text { 1950s Medium/Large } \\
\text { Barracks }\end{array}$ & $\begin{array}{c}\text { Distillate Oil Conventional Boiler / } \\
\text { Electric Package Unit }\end{array}$ & $\begin{array}{l}\text { Open-Loop Ground-Coupled } \\
\text { Heat Pump System }\end{array}$ & 5.1 & 2.4 & 124094 \\
\hline Appropriated & $\begin{array}{c}\text { 1950s Medium/Large } \\
\text { Barracks }\end{array}$ & $\begin{array}{c}\text { Distillate Oil Conventional Boiler / } \\
\text { Electric Package Unit }\end{array}$ & $\begin{array}{l}\text { Open-Loop Ground-Coupled } \\
\text { Heat Pump System }\end{array}$ & 4.5 & 3 & 143949 \\
\hline Appropriated & $\begin{array}{l}\text { 1950s Medium/Large } \\
\text { Barracks }\end{array}$ & $\begin{array}{c}\text { Distillate Oil Conventional Boiler / } \\
\text { Electric Package Unit }\end{array}$ & $\begin{array}{l}\text { Horizontal Closed-Loop } \\
\text { Ground-Coupled Heat Pump } \\
\text { System }\end{array}$ & 12.8 & 1.1 & 406348 \\
\hline Alternative & Mountain View Housing & $\begin{array}{c}\text { Propane Conventional Furnace / Electric } \\
\text { Package Unit }\end{array}$ & $\begin{array}{l}\text { Open-Loop Ground-Coupled } \\
\text { Heat Pump System }\end{array}$ & 8 & 1.9 & 915827 \\
\hline Appropriated & Mountain View Housing & $\begin{array}{c}\text { Propane Conventional Furnace / Electric } \\
\text { Package Unit }\end{array}$ & $\begin{array}{l}\text { Open-Loop Ground-Coupled } \\
\text { Heat Pump System }\end{array}$ & 8.4 & 1.4 & 1062360 \\
\hline Alternative & Mountain View Housing & $\begin{array}{c}\text { Propane Conventional Furnace / Electric } \\
\text { Package Unit }\end{array}$ & $\begin{array}{l}\text { Horizontal Closed-Loop } \\
\text { Ground-Coupled Heat Pump } \\
\text { System }\end{array}$ & 7.3 & 2 & 861878 \\
\hline Appropriated & Mountain View Housing & $\begin{array}{c}\text { Propane Conventional Furnace / Electric } \\
\text { Package Unit }\end{array}$ & $\begin{array}{c}\text { Horizontal Closed-Loop } \\
\text { Ground-Coupled Heat Pump } \\
\text { System }\end{array}$ & 7.6 & 1.6 & 999778 \\
\hline Alternative & Mountain View Housing & $\begin{array}{c}\text { Propane Conventional Furnace / Electric } \\
\text { Package Unit }\end{array}$ & $\begin{array}{c}\text { Vertical Closed-Loop } \\
\text { Ground-Coupled Heat Pump } \\
\text { System }\end{array}$ & 8.8 & 1.7 & 1034375 \\
\hline Appropriated & Mountain View Housing & $\begin{array}{c}\text { Propane Conventional Furnace / Electric } \\
\text { Package Unit }\end{array}$ & $\begin{array}{l}\text { Vertical Closed-Loop } \\
\text { Ground-Coupled Heat Pump } \\
\text { System }\end{array}$ & 9.1 & 1.4 & 1199875 \\
\hline Alternative & St John Park & $\begin{array}{c}\text { Propane Conventional Furnace / Electric } \\
\text { Package Unit }\end{array}$ & $\begin{array}{l}\text { Open-Loop Ground-Coupled } \\
\text { Heat Pump System }\end{array}$ & 7.9 & 1.9 & 316283 \\
\hline Appropriated & St John Park & $\begin{array}{c}\text { Propane Conventional Furnace / Electric } \\
\text { Package Unit }\end{array}$ & $\begin{array}{l}\text { Open-Loop Ground-Coupled } \\
\text { Heat Pump System }\end{array}$ & 8.7 & 2.2 & 366888 \\
\hline Alternative & St John Park & $\begin{array}{c}\text { Propane Conventional Furnace / Electric } \\
\text { Package Unit }\end{array}$ & $\begin{array}{l}\text { Horizontal Closed-Loop } \\
\text { Ground-Coupled Heat Pump } \\
\text { System }\end{array}$ & 6.7 & 2.3 & 261718 \\
\hline Appropriated & St John Park & $\begin{array}{c}\text { Propane Conventional Furnace / Electric } \\
\text { Package Unit }\end{array}$ & $\begin{array}{c}\text { Horizontal Closed-Loop } \\
\text { Ground-Coupled Heat Pump } \\
\text { System }\end{array}$ & 7.2 & 2.8 & 303593 \\
\hline Alternative & St John Park & $\begin{array}{c}\text { Propane Conventional Furnace / Electric } \\
\text { Package Unit }\end{array}$ & $\begin{array}{l}\text { Vertical Closed-Loop } \\
\text { Ground-Coupled Heat Pump } \\
\text { System }\end{array}$ & 8.9 & 1.7 & 350321 \\
\hline Appropriated & St John Park & $\begin{array}{c}\text { Propane Conventional Furnace / Electric } \\
\text { Package Unit }\end{array}$ & $\begin{array}{c}\text { Vertical Closed-Loop } \\
\text { Ground-Coupled Heat Pump } \\
\text { System }\end{array}$ & 9.6 & 2 & 406372 \\
\hline Alternative & Hotel/Guesthouse & $\begin{array}{c}\text { Propane Conventional Boiler / Electric } \\
\text { Air-Cooled Chiller }\end{array}$ & $\begin{array}{l}\text { Open-Loop Ground-Coupled } \\
\text { Heat Pump System }\end{array}$ & 3.2 & 4.7 & 49086 \\
\hline
\end{tabular}




\begin{tabular}{|c|c|c|c|c|c|c|}
\hline $\begin{array}{l}\text { Funding } \\
\text { Source }\end{array}$ & Building Set Description & Current Heating and Cooling Technology & Retrofit Technology & $\begin{array}{l}\text { Payback } \\
\text { Period }\end{array}$ & SIR & $\begin{array}{l}\text { Installed } \\
\text { Capital } \\
\text { Cost }(\$)\end{array}$ \\
\hline Alternative & Hotel/Guesthouse & $\begin{array}{c}\text { Distillate Oil Conventional Boiler / } \\
\text { Electric Package Unit }\end{array}$ & $\begin{array}{l}\text { Open-Loop Ground-Coupled } \\
\text { Heat Pump System }\end{array}$ & 4.2 & 3 & 32724 \\
\hline Appropriated & Hotel/Guesthouse & $\begin{array}{c}\text { Propane Conventional Boiler / Electric } \\
\text { Air-Cooled Chiller }\end{array}$ & $\begin{array}{l}\text { Open-Loop Ground-Coupled } \\
\text { Heat Pump System }\end{array}$ & 2.9 & 6.7 & 56939 \\
\hline Appropriated & Hotel/Guesthouse & $\begin{array}{c}\text { Distillate Oil Conventional Boiler / } \\
\text { Electric Package Unit }\end{array}$ & $\begin{array}{l}\text { Open-Loop Ground-Coupled } \\
\text { Heat Pump System }\end{array}$ & 4.4 & 3.1 & 37960 \\
\hline Alternative & Hotel/Guesthouse & $\begin{array}{c}\text { Propane Conventional Boiler / Electric } \\
\text { Air-Cooled Chiller }\end{array}$ & $\begin{array}{c}\text { Horizontal Closed-Loop } \\
\text { Ground-Coupled Heat Pump } \\
\text { System }\end{array}$ & 7.6 & 2 & 109823 \\
\hline Alternative & Hotel/Guesthouse & $\begin{array}{c}\text { Distillate Oil Conventional Boiler / } \\
\text { Electric Package Unit }\end{array}$ & $\begin{array}{c}\text { Horizontal Closed-Loop } \\
\text { Ground-Coupled Heat Pump } \\
\text { System }\end{array}$ & 10.6 & 1.3 & 73216 \\
\hline Appropriated & Hotel/Guesthouse & $\begin{array}{c}\text { Propane Conventional Boiler / Electric } \\
\text { Air-Cooled Chiller }\end{array}$ & $\begin{array}{c}\text { Horizontal Closed-Loop } \\
\text { Ground-Coupled Heat Pump } \\
\text { System }\end{array}$ & 6.8 & 2.9 & 127395 \\
\hline Appropriated & Hotel/Guesthouse & $\begin{array}{c}\text { Distillate Oil Conventional Boiler / } \\
\text { Electric Package Unit }\end{array}$ & $\begin{array}{c}\text { Horizontal Closed-Loop } \\
\text { Ground-Coupled Heat Pump } \\
\text { System }\end{array}$ & 10.4 & 1.3 & 84930 \\
\hline Alternative & Hotel/Guesthouse & $\begin{array}{c}\text { Propane Conventional Boiler / Electric } \\
\text { Air-Cooled Chiller }\end{array}$ & $\begin{array}{l}\text { Vertical Closed-Loop } \\
\text { Ground-Coupled Heat Pump } \\
\text { System }\end{array}$ & 8.7 & 1.8 & 127271 \\
\hline Alternative & Hotel/Guesthouse & $\begin{array}{c}\text { Distillate Oil Conventional Boiler / } \\
\text { Electric Package Unit }\end{array}$ & $\begin{array}{c}\text { Vertical Closed-Loop } \\
\text { Ground-Coupled Heat Pump } \\
\text { System }\end{array}$ & 12 & 1.1 & 84847 \\
\hline Appropriated & Hotel/Guesthouse & $\begin{array}{l}\text { Propane Conventional Boiler / Electric } \\
\text { Air-Cooled Chiller }\end{array}$ & $\begin{array}{l}\text { Vertical Closed-Loop } \\
\text { Ground-Coupled Heat Pump } \\
\text { System }\end{array}$ & 7.8 & 2.5 & 147635 \\
\hline Appropriated & Hotel/Guesthouse & $\begin{array}{c}\text { Distillate Oil Conventional Boiler / } \\
\text { Electric Package Unit }\end{array}$ & $\begin{array}{c}\text { Vertical Closed-Loop } \\
\text { Ground-Coupled Heat Pump } \\
\text { System }\end{array}$ & 11.8 & 1.2 & 98423 \\
\hline Alternative & 1950s Conditioned Storage & $\begin{array}{c}\text { Propane Conventional Furnace / Electric } \\
\text { Package Unit }\end{array}$ & $\begin{array}{l}\text { Horizontal Closed-Loop } \\
\text { Ground-Coupled Heat Pump } \\
\text { System }\end{array}$ & 14.2 & 1.1 & 101029 \\
\hline Appropriated & 1950s Conditioned Storage & $\begin{array}{c}\text { Propane Conventional Furnace / Electric } \\
\text { Package Unit }\end{array}$ & $\begin{array}{c}\text { Horizontal Closed-Loop } \\
\text { Ground-Coupled Heat Pump } \\
\text { System }\end{array}$ & 13.4 & 1.2 & 117194 \\
\hline Alternative & 1950s Conditioned Storage & $\begin{array}{c}\text { Propane Conventional Furnace / Electric } \\
\text { Package Unit }\end{array}$ & $\begin{array}{c}\text { Vertical Closed-Loop } \\
\text { Ground-Coupled Heat Pump } \\
\text { System }\end{array}$ & 14.2 & 1.1 & 98105 \\
\hline Appropriated & 1950s Conditioned Storage & $\begin{array}{c}\text { Propane Conventional Furnace / Electric } \\
\text { Package Unit }\end{array}$ & $\begin{array}{c}\text { Vertical Closed-Loop } \\
\text { Ground-Coupled Heat Pump } \\
\text { System }\end{array}$ & 13.3 & 1.2 & 113802 \\
\hline Alternative & Utility Buildings & $\begin{array}{c}\text { Propane Conventional Boiler / Electric } \\
\text { Package Unit }\end{array}$ & $\begin{array}{l}\text { Open-Loop Ground-Coupled } \\
\text { Heat Pump System }\end{array}$ & 10.4 & 1.5 & 47114 \\
\hline Appropriated & Utility Buildings & $\begin{array}{c}\text { Distillate Oil Conventional Boiler / } \\
\text { Electric Package Unit }\end{array}$ & $\begin{array}{l}\text { Open-Loop Ground-Coupled } \\
\text { Heat Pump System }\end{array}$ & 13.2 & 1 & 218609 \\
\hline Appropriated & Utility Buildings & $\begin{array}{c}\text { Propane Conventional Boiler / Electric } \\
\text { Package Unit }\end{array}$ & $\begin{array}{l}\text { Open-Loop Ground-Coupled } \\
\text { Heat Pump System }\end{array}$ & 10.1 & 1.6 & 54652 \\
\hline Alternative & Utility Buildings & $\begin{array}{c}\text { Distillate Oil Conventional Boiler / } \\
\text { Electric Package Unit }\end{array}$ & $\begin{array}{c}\text { Horizontal Closed-Loop } \\
\text { Ground-Coupled Heat Pump } \\
\text { System }\end{array}$ & 8.4 & 1.6 & 105271 \\
\hline
\end{tabular}




\begin{tabular}{|c|c|c|c|c|c|c|}
\hline $\begin{array}{l}\text { Funding } \\
\text { Source }\end{array}$ & Building Set Description & Current Heating and Cooling Technology & Retrofit Technology & $\begin{array}{l}\text { Payback } \\
\text { Period }\end{array}$ & SIR & $\begin{array}{l}\text { Installed } \\
\text { Capital } \\
\text { Cost (\$) }\end{array}$ \\
\hline Alternative & Utility Buildings & $\begin{array}{c}\text { Propane Conventional Boiler / Electric } \\
\text { Package Unit }\end{array}$ & $\begin{array}{c}\text { Horizontal Closed-Loop } \\
\text { Ground-Coupled Heat Pump } \\
\text { System }\end{array}$ & 5.9 & 2.7 & 26318 \\
\hline Appropriated & Utility Buildings & $\begin{array}{c}\text { Distillate Oil Conventional Boiler / } \\
\text { Electric Package Unit }\end{array}$ & $\begin{array}{c}\text { Horizontal Closed-Loop } \\
\text { Ground-Coupled Heat Pump } \\
\text { System }\end{array}$ & 7.6 & 1.8 & 128604 \\
\hline Appropriated & Utility Buildings & $\begin{array}{c}\text { Propane Conventional Boiler / Electric } \\
\text { Package Unit }\end{array}$ & $\begin{array}{c}\text { Horizontal Closed-Loop } \\
\text { Ground-Coupled Heat Pump } \\
\text { System }\end{array}$ & 5.9 & 2.8 & 32151 \\
\hline Alternative & Utility Buildings & $\begin{array}{c}\text { Propane Conventional Boiler / Electric } \\
\text { Package Unit }\end{array}$ & $\begin{array}{l}\text { Vertical Closed-Loop } \\
\text { Ground-Coupled Heat Pump } \\
\text { System }\end{array}$ & 9.5 & 1.6 & 44032 \\
\hline Appropriated & Utility Buildings & $\begin{array}{c}\text { Distillate Oil Conventional Boiler / } \\
\text { Electric Package Unit }\end{array}$ & $\begin{array}{l}\text { Vertical Closed-Loop } \\
\text { Ground-Coupled Heat Pump } \\
\text { System }\end{array}$ & 11.9 & 1.2 & 204309 \\
\hline Appropriated & Utility Buildings & $\begin{array}{c}\text { Propane Conventional Boiler / Electric } \\
\text { Package Unit }\end{array}$ & $\begin{array}{c}\text { Vertical Closed-Loop } \\
\text { Ground-Coupled Heat Pump } \\
\text { System }\end{array}$ & 9.2 & 1.8 & 51077 \\
\hline Alternative & $\begin{array}{l}\text { 1950s Medium Maintenance } \\
\text { Facility, Admin/Shop Area }\end{array}$ & $\begin{array}{c}\text { Propane Conventional Boiler / Electric } \\
\text { Package Unit }\end{array}$ & $\begin{array}{l}\text { Open-Loop Ground-Coupled } \\
\text { Heat Pump System }\end{array}$ & 7 & 2 & 89301 \\
\hline Appropriated & $\begin{array}{l}\text { 1950s Medium Maintenance } \\
\text { Facility, Admin/Shop Area }\end{array}$ & $\begin{array}{c}\text { Propane Conventional Boiler / Electric } \\
\text { Package Unit }\end{array}$ & $\begin{array}{l}\text { Open-Loop Ground-Coupled } \\
\text { Heat Pump System }\end{array}$ & 7 & 2.2 & 103589 \\
\hline Alternative & $\begin{array}{l}\text { 1950s Medium Maintenance } \\
\text { Facility, Admin/Shop Area }\end{array}$ & $\begin{array}{c}\text { Propane Conventional Boiler / Electric } \\
\text { Package Unit }\end{array}$ & $\begin{array}{c}\text { Horizontal Closed-Loop } \\
\text { Ground-Coupled Heat Pump } \\
\text { System }\end{array}$ & 10 & 1.4 & 134624 \\
\hline Appropriated & $\begin{array}{l}\text { 1950s Medium Maintenance } \\
\text { Facility, Admin/Shop Area }\end{array}$ & $\begin{array}{c}\text { Propane Conventional Boiler / Electric } \\
\text { Package Unit }\end{array}$ & $\begin{array}{c}\text { Horizontal Closed-Loop } \\
\text { Ground-Coupled Heat Pump } \\
\text { System }\end{array}$ & 10.2 & 1.5 & 156163 \\
\hline Appropriated & $\begin{array}{l}\text { 1950s Medium Maintenance } \\
\text { Facility, Admin/Shop Area }\end{array}$ & $\begin{array}{c}\text { Distillate 0il Conventional Furnace / } \\
\text { Electric Package Unit }\end{array}$ & $\begin{array}{c}\text { Horizontal Closed-Loop } \\
\text { Ground-Coupled Heat Pump } \\
\text { System }\end{array}$ & 12 & 1.1 & 95709 \\
\hline Appropriated & $\begin{array}{l}\text { 1950s Medium Maintenance } \\
\text { Facility, Admin/Shop Area }\end{array}$ & $\begin{array}{c}\text { Distillate Oil Conventional Furnace / } \\
\text { Electric Package Unit }\end{array}$ & $\begin{array}{l}\text { Horizontal Closed-Loop } \\
\text { Ground-Coupled Heat Pump } \\
\text { System }\end{array}$ & 12 & 1.1 & 63659 \\
\hline Alternative & $\begin{array}{l}\text { 1950s Medium Maintenance } \\
\text { Facility, Admin/Shop Area }\end{array}$ & $\begin{array}{c}\text { Propane Conventional Boiler / Electric } \\
\text { Package Unit }\end{array}$ & $\begin{array}{l}\text { Vertical Closed-Loop } \\
\text { Ground-Coupled Heat Pump } \\
\text { System }\end{array}$ & 11.8 & 1.2 & 161680 \\
\hline Appropriated & $\begin{array}{l}\text { 1950s Medium Maintenance } \\
\text { Facility, Admin/Shop Area }\end{array}$ & $\begin{array}{c}\text { Propane Conventional Boiler / Electric } \\
\text { Package Unit }\end{array}$ & $\begin{array}{c}\text { Vertical Closed-Loop } \\
\text { Ground-Coupled Heat Pump } \\
\text { System }\end{array}$ & 11.7 & 1.3 & 187549 \\
\hline Alternative & $\begin{array}{l}\text { 1950s Medium Maintenance } \\
\text { Facility, High Bay Area }\end{array}$ & $\begin{array}{c}\text { Propane Conventional Boiler / Electric } \\
\text { Package Unit }\end{array}$ & $\begin{array}{l}\text { Open-Loop Ground-Coupled } \\
\text { Heat Pump System }\end{array}$ & 3.3 & 4.5 & 4962 \\
\hline Alternative & $\begin{array}{l}\text { 1950s Medium Maintenance } \\
\text { Facility, High Bay Area }\end{array}$ & $\begin{array}{c}\text { Distillate Oil Conventional Boiler / } \\
\text { Electric Package Unit }\end{array}$ & $\begin{array}{l}\text { Open-Loop Ground-Coupled } \\
\text { Heat Pump System }\end{array}$ & 4.8 & 2.6 & 4962 \\
\hline Appropriated & $\begin{array}{l}\text { 1950s Medium Maintenance } \\
\text { Facility, High Bay Area }\end{array}$ & $\begin{array}{c}\text { Propane Conventional Boiler / Electric } \\
\text { Package Unit }\end{array}$ & $\begin{array}{l}\text { Open-Loop Ground-Coupled } \\
\text { Heat Pump System }\end{array}$ & 3.5 & 4.7 & 5755 \\
\hline Appropriated & $\begin{array}{l}\text { 1950s Medium Maintenance } \\
\text { Facility, High Bay Area }\end{array}$ & $\begin{array}{c}\text { Electric Conventional Furnace / Electric } \\
\text { Package Unit }\end{array}$ & $\begin{array}{l}\text { Open-Loop Ground-Coupled } \\
\text { Heat Pump System }\end{array}$ & 11.1 & 1.2 & 13037 \\
\hline Appropriated & $\begin{array}{l}\text { 1950s Medium Maintenance } \\
\text { Facility, High Bay Area }\end{array}$ & $\begin{array}{c}\text { Distillate Oil Conventional Boiler / } \\
\text { Electric Package Unit }\end{array}$ & $\begin{array}{l}\text { Open-Loop Ground-Coupled } \\
\text { Heat Pump System }\end{array}$ & 4.9 & 2.7 & 5755 \\
\hline
\end{tabular}




\begin{tabular}{|c|c|c|c|c|c|c|}
\hline $\begin{array}{l}\text { Funding } \\
\text { Source }\end{array}$ & Building Set Description & Current Heating and Cooling Technology & Retrofit Technology & $\begin{array}{l}\text { Payback } \\
\text { Period }\end{array}$ & SIR & $\begin{array}{l}\text { Installed } \\
\text { Capital } \\
\text { Cost (\$) }\end{array}$ \\
\hline Alternative & $\begin{array}{l}\text { 1950s Medium Maintenance } \\
\text { Facility, High Bay Area }\end{array}$ & $\begin{array}{c}\text { Propane Conventional Boiler / Electric } \\
\text { Package Unit }\end{array}$ & $\begin{array}{c}\text { Horizontal Closed-Loop } \\
\text { Ground-Coupled Heat Pump } \\
\text { System } \\
\end{array}$ & 5.5 & 2.8 & 7920 \\
\hline Alternative & $\begin{array}{l}\text { 1950s Medium Maintenance } \\
\text { Facility, High Bay Area }\end{array}$ & $\begin{array}{c}\text { Distillate Oil Conventional Boiler / } \\
\text { Electric Package Unit }\end{array}$ & $\begin{array}{l}\text { Horizontal Closed-Loop } \\
\text { Ground-Coupled Heat Pump } \\
\text { System }\end{array}$ & 8.3 & 1.6 & 7920 \\
\hline Appropriated & $\begin{array}{l}\text { 1950s Medium Maintenance } \\
\text { Facility, High Bay Area }\end{array}$ & $\begin{array}{c}\text { Propane Conventional Boiler / Electric } \\
\text { Package Unit }\end{array}$ & $\begin{array}{c}\text { Horizontal Closed-Loop } \\
\text { Ground-Coupled Heat Pump } \\
\text { System }\end{array}$ & 5.7 & 2.9 & 9187 \\
\hline Appropriated & $\begin{array}{l}\text { 1950s Medium Maintenance } \\
\text { Facility, High Bay Area }\end{array}$ & $\begin{array}{c}\text { Distillate Oil Conventional Boiler / } \\
\text { Electric Package Unit }\end{array}$ & $\begin{array}{l}\text { Horizontal Closed-Loop } \\
\text { Ground-Coupled Heat Pump } \\
\text { System }\end{array}$ & 8.2 & 1.7 & 9187 \\
\hline Alternative & $\begin{array}{l}\text { 1950s Medium Maintenance } \\
\text { Facility, High Bay Area }\end{array}$ & $\begin{array}{c}\text { Propane Conventional Boiler / Electric } \\
\text { Package Unit }\end{array}$ & $\begin{array}{c}\text { Vertical Closed-Loop } \\
\text { Ground-Coupled Heat Pump } \\
\text { System }\end{array}$ & 7.5 & 2 & 11449 \\
\hline Alternative & $\begin{array}{l}\text { 1950s Medium Maintenance } \\
\text { Facility, High Bay Area }\end{array}$ & $\begin{array}{c}\text { Distillate Oil Conventional Boiler / } \\
\text { Electric Package Unit }\end{array}$ & $\begin{array}{c}\text { Vertical Closed-Loop } \\
\text { Ground-Coupled Heat Pump } \\
\text { System }\end{array}$ & 11.1 & 1.1 & 11449 \\
\hline Appropriated & $\begin{array}{l}\text { 1950s Medium Maintenance } \\
\text { Facility, High Bay Area }\end{array}$ & $\begin{array}{c}\text { Propane Conventional Boiler / Electric } \\
\text { Package Unit }\end{array}$ & $\begin{array}{c}\text { Vertical Closed-Loop } \\
\text { Ground-Coupled Heat Pump } \\
\text { System }\end{array}$ & 7.9 & 2 & 13280 \\
\hline Appropriated & $\begin{array}{l}\text { 1950s Medium Maintenance } \\
\text { Facility, High Bay Area }\end{array}$ & $\begin{array}{c}\text { Distillate Oil Conventional Boiler / } \\
\text { Electric Package Unit }\end{array}$ & $\begin{array}{c}\text { Vertical Closed-Loop } \\
\text { Ground-Coupled Heat Pump } \\
\text { System }\end{array}$ & 11.1 & 1.2 & 13280 \\
\hline Alternative & $\begin{array}{l}\text { Laboratory Building - } \\
\text { Life Sciences \& Others }\end{array}$ & $\begin{array}{c}\text { Distillate Oil Conventional Boiler / } \\
\text { Electric water-Cooled Reciprocating } \\
\text { Chiller }\end{array}$ & $\begin{array}{l}\text { Open-Loop Ground-Coupled } \\
\text { Heat Pump System }\end{array}$ & 1.1 & 12.3 & 266393 \\
\hline Alternative & $\begin{array}{l}\text { Laboratory Building - } \\
\text { Life Sciences \& Others }\end{array}$ & $\begin{array}{l}\text { Propane Conventional Boiler / Electric } \\
\text { Water-Cooled Reciprocating Chiller }\end{array}$ & $\begin{array}{l}\text { Open-Loop Ground-Coupled } \\
\text { Heat Pump System }\end{array}$ & 0.8 & 19.6 & 266393 \\
\hline Appropriated & $\begin{array}{l}\text { Laboratory Building - } \\
\text { Life Sciences \& Others }\end{array}$ & $\begin{array}{c}\text { Distillate Oil Conventional Boiler / } \\
\text { Electric Water-Cooled Reciprocating } \\
\text { Chiller }\end{array}$ & $\begin{array}{l}\text { Open-Loop Ground-Coupled } \\
\text { Heat Pump System }\end{array}$ & 1.2 & 11.7 & 309016 \\
\hline Appropriated & $\begin{array}{l}\text { Laboratory Building - } \\
\text { Life Sciences \& Others }\end{array}$ & $\begin{array}{l}\text { Propane Conventional Boiler / Electric } \\
\text { Water-Cooled Reciprocating Chiller }\end{array}$ & $\begin{array}{l}\text { Open-Loop Ground-Coupled } \\
\text { Heat Pump System }\end{array}$ & 0.9 & 14 & 309016 \\
\hline Alternative & $\begin{array}{l}\text { Laboratory Building - } \\
\text { Life Sciences \& Others }\end{array}$ & $\begin{array}{c}\text { Distillate Oil Conventional Boiler / } \\
\text { Electric Water-Cooled Reciprocating } \\
\text { Chiller }\end{array}$ & $\begin{array}{c}\text { Horizontal Closed-Loop } \\
\text { Ground-Coupled Heat Pump } \\
\text { System }\end{array}$ & 5.4 & 2.6 & 1119850 \\
\hline Alternative & $\begin{array}{l}\text { Laboratory Building - } \\
\text { Life Sciences \& Others }\end{array}$ & $\begin{array}{l}\text { Propane Conventional Boiler / Electric } \\
\text { Water-Cooled Reciprocating Chiller }\end{array}$ & $\begin{array}{c}\text { Horizontal Closed-Loop } \\
\text { Ground-Coupled Heat Pump } \\
\text { System }\end{array}$ & 3.8 & 4.3 & 1119850 \\
\hline Appropriated & $\begin{array}{l}\text { Laboratory Building - } \\
\text { Life Sciences \& Others }\end{array}$ & $\begin{array}{c}\text { Distillate Oil Conventional Boiler / } \\
\text { Electric Water-Cooled Reciprocating } \\
\text { Chiller }\end{array}$ & $\begin{array}{l}\text { Horizontal Closed-Loop } \\
\text { Ground-Coupled Heat Pump } \\
\text { System }\end{array}$ & 5.9 & 2.3 & 1299026 \\
\hline Appropriated & $\begin{array}{l}\text { Laboratory Building - } \\
\text { Life Sciences \& Others }\end{array}$ & $\begin{array}{l}\text { Propane Conventional Boiler / Electric } \\
\text { Water-Cooled Reciprocating Chiller }\end{array}$ & $\begin{array}{c}\text { Horizontal Closed-Loop } \\
\text { Ground-Coupled Heat Pump } \\
\text { System }\end{array}$ & 4.1 & 2.9 & 1299026 \\
\hline Alternative & $\begin{array}{l}\text { Laboratory Building - } \\
\text { Life Sciences \& Others }\end{array}$ & $\begin{array}{c}\text { Distillate Oil Conventional Boiler / } \\
\text { Electric Water-Cooled Reciprocating } \\
\text { Chiller }\end{array}$ & $\begin{array}{l}\text { Vertical Closed-Loop } \\
\text { Ground-Coupled Heat Pump } \\
\text { System }\end{array}$ & 10.2 & 1.3 & 2385050 \\
\hline
\end{tabular}




\begin{tabular}{|c|c|c|c|c|c|c|}
\hline $\begin{array}{l}\text { Funding } \\
\text { Source }\end{array}$ & Building Set Description & Current Heating and Cooling Technology & Retrofit Technology & $\begin{array}{l}\text { Payback } \\
\text { Period }\end{array}$ & SIR & $\begin{array}{l}\text { Installed } \\
\text { Capital } \\
\text { Cost }(\$)\end{array}$ \\
\hline Alternative & $\begin{array}{l}\text { Laboratory Building - } \\
\text { Life Sciences \& Others }\end{array}$ & $\begin{array}{l}\text { Propane Conventional Boiler / Electric } \\
\text { Water-Cooled Reciprocating Chiller }\end{array}$ & $\begin{array}{c}\text { Vertical Closed-Loop } \\
\text { Ground-Coupled Heat Pump } \\
\text { System }\end{array}$ & 7.4 & 2.1 & 2385050 \\
\hline Appropriated & $\begin{array}{l}\text { Laboratory Building - } \\
\text { Life Sciences \& Others }\end{array}$ & $\begin{array}{c}\text { Distillate Oil Conventional Boiler / } \\
\text { Electric water-Cooled Reciprocating } \\
\text { Chiller }\end{array}$ & $\begin{array}{l}\text { Vertical Closed-Loop } \\
\text { Ground-Coupled Heat Pump } \\
\text { System }\end{array}$ & 11.3 & 1.2 & 2766658 \\
\hline Appropriated & $\begin{array}{l}\text { Laboratory Building - } \\
\text { Life Sciences \& Others }\end{array}$ & $\begin{array}{l}\text { Propane Conventional Boiler / Electric } \\
\text { Water-Cooled Reciprocating Chiller }\end{array}$ & $\begin{array}{l}\text { Vertical Closed-Loop } \\
\text { Ground-Coupled Heat Pump } \\
\text { System }\end{array}$ & 8.1 & 1.5 & 2766658 \\
\hline Alternative & Materials Test Facility & $\begin{array}{c}\text { Propane Conventional Boiler / Electric } \\
\text { Air-Cooled Chiller }\end{array}$ & $\begin{array}{l}\text { Open-Loop Ground-Coupled } \\
\text { Heat Pump System }\end{array}$ & 1.4 & 10.1 & 108735 \\
\hline Appropriated & Materials Test Facility & $\begin{array}{c}\text { Propane Conventional Boiler / Electric } \\
\text { Air-Cooled Chiller }\end{array}$ & $\begin{array}{l}\text { Open-Loop Ground-Coupled } \\
\text { Heat Pump System }\end{array}$ & 1.4 & 9.1 & 126133 \\
\hline Alternative & Materials Test Facility & $\begin{array}{l}\text { Propane Conventional Boiler / Electric } \\
\text { Air-Cooled Chiller }\end{array}$ & $\begin{array}{l}\text { Horizontal Closed-Loop } \\
\text { Ground-Coupled Heat Pump } \\
\text { System }\end{array}$ & 5 & 3 & 339624 \\
\hline Appropriated & Materials Test Facility & $\begin{array}{l}\text { Propane Conventional Boiler / Electric } \\
\text { Air-Cooled Chiller }\end{array}$ & $\begin{array}{c}\text { Horizontal Closed-Loop } \\
\text { Ground-Coupled Heat Pump } \\
\text { System }\end{array}$ & 4.8 & 2.7 & 393964 \\
\hline Alternative & Materials Test Facility & $\begin{array}{l}\text { Propane Conventional Boiler / Electric } \\
\text { Air-Cooled Chiller }\end{array}$ & $\begin{array}{l}\text { Vertical Closed-Loop } \\
\text { Ground-Coupled Heat Pump } \\
\text { System }\end{array}$ & 7.2 & 2.1 & 495593 \\
\hline Appropriated & Materials Test Facility & $\begin{array}{l}\text { Propane Conventional Boiler / Electric } \\
\text { Air-Cooled Chiller }\end{array}$ & $\begin{array}{c}\text { Vertical Closed-Loop } \\
\text { Ground-Coupled Heat Pump } \\
\text { System }\end{array}$ & 6.9 & 1.9 & 574888 \\
\hline Alternative & 1990s Small Laboratory & $\begin{array}{c}\text { Propane Conventional Boiler / Electric } \\
\text { Package Unit }\end{array}$ & $\begin{array}{l}\text { Open-Loop Ground-Coupled } \\
\text { Heat Pump System }\end{array}$ & 8.8 & 1.6 & 13919 \\
\hline Appropriated & 1990s Small Laboratory & $\begin{array}{c}\text { Distillate Oil Conventional Boiler / } \\
\text { Electric Package Unit }\end{array}$ & $\begin{array}{l}\text { Open-Loop Ground-Coupled } \\
\text { Heat Pump System }\end{array}$ & 11.2 & 1.2 & 80731 \\
\hline Appropriated & 1990s Small Laboratory & $\begin{array}{c}\text { Propane Conventional Boiler / Electric } \\
\text { Package Unit }\end{array}$ & $\begin{array}{l}\text { Open-Loop Ground-Coupled } \\
\text { Heat Pump System }\end{array}$ & 8.7 & 1.8 & 16146 \\
\hline Appropriated & 1990s Small Laboratory & $\begin{array}{c}\text { Propane Conventional Boiler / Electric } \\
\text { Package Unit }\end{array}$ & $\begin{array}{l}\text { Horizontal Closed-Loop } \\
\text { Ground-Coupled Heat Pump } \\
\text { System }\end{array}$ & 14.9 & 1 & 28585 \\
\hline Alternative & 1950-60s Small Laboratory & $\begin{array}{l}\text { Propane Conventional Boiler / Electric } \\
\text { Water-Cooled Reciprocating Chiller }\end{array}$ & $\begin{array}{l}\text { Open-Loop Ground-Coupled } \\
\text { Heat Pump System }\end{array}$ & 2.7 & 5.5 & 409663 \\
\hline Alternative & 1950-60s Small Laboratory & $\begin{array}{l}\text { Distillate Oil Conventional Boiler / } \\
\text { Electric Air-Cooled Chiller }\end{array}$ & $\begin{array}{l}\text { Open-Loop Ground-Coupled } \\
\text { Heat Pump System }\end{array}$ & 3.3 & 3.7 & 143936 \\
\hline Appropriated & 1950-60s Small Laboratory & $\begin{array}{l}\text { Propane Conventional Boiler / Electric } \\
\text { Water-Cooled Reciprocating chiller }\end{array}$ & $\begin{array}{l}\text { Open-Loop Ground-Coupled } \\
\text { Heat Pump System }\end{array}$ & 2.4 & 7.1 & 475209 \\
\hline Appropriated & 1950-60s Small Laboratory & $\begin{array}{c}\text { Distillate 0il Conventional Boiler / } \\
\text { Electric Air-Cooled Chiller }\end{array}$ & $\begin{array}{l}\text { Open-Loop Ground-Coupled } \\
\text { Heat Pump System }\end{array}$ & 3.5 & 4.3 & 166965 \\
\hline Alternative & 1950-60s Small Laboratory & $\begin{array}{l}\text { Propane Conventional Boiler / Electric } \\
\text { Water-Cooled Reciprocating Chiller }\end{array}$ & $\begin{array}{l}\text { Horizontal Closed-Loop } \\
\text { Ground-Coupled Heat Pump } \\
\text { System }\end{array}$ & 9.2 & 1.7 & 1227618 \\
\hline Alternative & 1950-60s Small Laboratory & $\begin{array}{c}\text { Distillate oil Conventional Boiler } \\
\text { Electric Air-Cooled Chiller }\end{array}$ & $\begin{array}{c}\text { Horizontal Closed-Loop } \\
\text { Ground-Coupled Heat Pump } \\
\text { System }\end{array}$ & 11.5 & 1.1 & 431325 \\
\hline Appropriated & 1950-60s Small Laboratory & Propane Conventional Boiler / Electric & Horizontal Closed-Loop & 7.9 & 2.3 & 1424037 \\
\hline
\end{tabular}




\begin{tabular}{|c|c|c|c|c|c|c|}
\hline $\begin{array}{l}\text { Funding } \\
\text { Source }\end{array}$ & Building Set Description & Current Heating and Cooling Technology & Retrofit Technology & $\begin{array}{l}\text { Payback } \\
\text { Period }\end{array}$ & SIR & $\begin{array}{l}\text { Installed } \\
\text { Capital } \\
\text { Cost }(\$)\end{array}$ \\
\hline & & Water-Cooled Reciprocating Chiller & $\begin{array}{c}\text { Ground-Coupled Heat Pump } \\
\text { System }\end{array}$ & & & \\
\hline Appropriated & 1950-60s Small Laboratory & $\begin{array}{l}\text { Distillate Oil Conventional Boiler } \\
\text { Electric Air-Cooled Chiller }\end{array}$ & $\begin{array}{c}\text { Horizontal Closed-Loop } \\
\text { Ground-Coupled Heat Pump } \\
\text { System }\end{array}$ & 11.4 & 1.3 & 500337 \\
\hline Alternative & 1950-60s Small Laboratory & $\begin{array}{l}\text { Propane Conventional Boiler / Electric } \\
\text { Water-Cooled Reciprocating Chiller }\end{array}$ & $\begin{array}{c}\text { Vertical Closed-Loop } \\
\text { Ground-Coupled Heat Pump } \\
\text { System }\end{array}$ & 10 & 1.5 & 1401372 \\
\hline Appropriated & 1950-60s Small Laboratory & $\begin{array}{l}\text { Propane Conventional Boiler / Electric } \\
\text { Water-Cooled Reciprocating Chiller }\end{array}$ & $\begin{array}{c}\text { Vertical Closed-Loop } \\
\text { Ground-Coupled Heat Pump } \\
\text { System }\end{array}$ & 8.9 & 2 & 1625593 \\
\hline Appropriated & 1950-60s Small Laboratory & $\begin{array}{l}\text { Distillate Oil Conventional Boiler } \\
\text { Electric Air-Cooled Chiller }\end{array}$ & $\begin{array}{l}\text { Vertical Closed-Loop } \\
\text { Ground-Coupled Heat Pump } \\
\text { System }\end{array}$ & 12.7 & 1.2 & 571154 \\
\hline Alternative & $\begin{array}{c}1940-50 \text { s Large } \\
\text { Maintenance Facility, } \\
\text { Admin Area }\end{array}$ & $\begin{array}{c}\text { Propane Conventional Furnace / Electric } \\
\text { Package Unit }\end{array}$ & $\begin{array}{c}\text { Open-Loop Ground-Coupled } \\
\text { Heat Pump System }\end{array}$ & 3.6 & 4.1 & 69690 \\
\hline Alternative & $\begin{array}{c}1940-50 \text { s Large } \\
\text { Maintenance Facility, } \\
\text { Admin Area } \\
\end{array}$ & $\begin{array}{c}\text { Distillate Oil Conventional Boiler / } \\
\text { Electric Package Unit }\end{array}$ & $\begin{array}{l}\text { Open-Loop Ground-Coupled } \\
\text { Heat Pump System }\end{array}$ & 4.6 & 2.7 & 32437 \\
\hline Appropriated & $\begin{array}{c}1940-50 \text { s Large } \\
\text { Maintenance Facility, } \\
\text { Admin Area }\end{array}$ & $\begin{array}{c}\text { Propane Conventional Furnace / Electric } \\
\text { Package Unit }\end{array}$ & $\begin{array}{l}\text { Open-Loop Ground-Coupled } \\
\text { Heat Pump System }\end{array}$ & 3.8 & 4.8 & 80841 \\
\hline Appropriated & $\begin{array}{c}1940-50 \text { s Large } \\
\text { Maintenance Facility, } \\
\text { Admin Area }\end{array}$ & $\begin{array}{c}\text { Distillate Oil Conventional Boiler / } \\
\text { Electric Package Unit }\end{array}$ & $\begin{array}{l}\text { Open-Loop Ground-Coupled } \\
\text { Heat Pump System }\end{array}$ & 4.6 & 3.3 & 37626 \\
\hline Alternative & $\begin{array}{c}1940-50 \text { s Large } \\
\text { Maintenance Facility, } \\
\text { Admin Area }\end{array}$ & $\begin{array}{c}\text { Propane Conventional Furnace / Electric } \\
\text { Package Unit }\end{array}$ & $\begin{array}{l}\text { Horizontal Closed-Loop } \\
\text { Ground-Coupled Heat Pump } \\
\text { System }\end{array}$ & 7.3 & 2.1 & 131508 \\
\hline Alternative & $\begin{array}{c}1940-50 \text { s Large } \\
\text { Maintenance Facility, } \\
\text { Admin Area }\end{array}$ & $\begin{array}{c}\text { Distillate Oil Conventional Boiler / } \\
\text { Electric Package Unit }\end{array}$ & $\begin{array}{c}\text { Horizontal Closed-Loop } \\
\text { Ground-Coupled Heat Pump } \\
\text { System }\end{array}$ & 9.4 & 1.4 & 61512 \\
\hline Appropriated & $\begin{array}{c}1940-50 \text { s Large } \\
\text { Maintenance Facility, } \\
\text { Admin Area }\end{array}$ & $\begin{array}{c}\text { Propane Conventional Furnace / Electric } \\
\text { Package Unit }\end{array}$ & $\begin{array}{c}\text { Horizontal Closed-Loop } \\
\text { Ground-Coupled Heat Pump } \\
\text { System }\end{array}$ & 7.5 & 2.5 & 152550 \\
\hline Appropriated & $\begin{array}{c}1940-50 \text { s Large } \\
\text { Maintenance Facility, } \\
\text { Admin Area } \\
\end{array}$ & $\begin{array}{c}\text { Distillate Oil Conventional Boiler / } \\
\text { Electric Package Unit }\end{array}$ & $\begin{array}{l}\text { Horizontal Closed-Loop } \\
\text { Ground-Coupled Heat Pump } \\
\text { System } \\
\end{array}$ & 9.3 & 1.7 & 71354 \\
\hline Alternative & $\begin{array}{c}1940-50 \text { s Large } \\
\text { Maintenance Facility, } \\
\text { Admin Area }\end{array}$ & $\begin{array}{c}\text { Propane Conventional Furnace / Electric } \\
\text { Package Unit }\end{array}$ & $\begin{array}{c}\text { Vertical Closed-Loop } \\
\text { Ground-Coupled Heat Pump } \\
\text { System }\end{array}$ & 8.7 & 1.7 & 164596 \\
\hline Alternative & $\begin{array}{c}1940-50 \text { s Large } \\
\text { Maintenance Facility, } \\
\text { Admin Area }\end{array}$ & $\begin{array}{c}\text { Distillate Oil Conventional Boiler / } \\
\text { Electric Package Unit }\end{array}$ & $\begin{array}{c}\text { Vertical Closed-Loop } \\
\text { Ground-Coupled Heat Pump } \\
\text { System }\end{array}$ & 11.1 & 1.2 & 70722 \\
\hline Appropriated & $\begin{array}{c}1940-50 \text { s Large } \\
\text { Maintenance Facility, } \\
\text { Admin Area }\end{array}$ & $\begin{array}{c}\text { Propane Conventional Furnace / Electric } \\
\text { Package Unit }\end{array}$ & $\begin{array}{c}\text { Vertical Closed-Loop } \\
\text { Ground-Coupled Heat Pump } \\
\text { System }\end{array}$ & 9.1 & 2 & 190932 \\
\hline Appropriated & $\begin{array}{c}1940-50 \text { s Large } \\
\text { Maintenance Facility, } \\
\text { Admin Area }\end{array}$ & $\begin{array}{c}\text { Distillate Oil Conventional Boiler / } \\
\text { Electric Package Unit }\end{array}$ & $\begin{array}{c}\text { Vertical Closed-Loop } \\
\text { Ground-Coupled Heat Pump } \\
\text { System }\end{array}$ & 10.9 & 1.4 & 82038 \\
\hline
\end{tabular}




\begin{tabular}{|c|c|c|c|c|c|c|}
\hline $\begin{array}{l}\text { Funding } \\
\text { Source }\end{array}$ & Building Set Description & Current Heating and Cooling Technology & Retrofit Technology & $\begin{array}{l}\text { Payback } \\
\text { Period }\end{array}$ & SIR & $\begin{array}{l}\text { Installed } \\
\text { Capital } \\
\text { Cost }(\$)\end{array}$ \\
\hline Alternative & Security Facility & $\begin{array}{c}\text { Distillate Oil Conventional Boiler / } \\
\text { Electric Package Unit }\end{array}$ & $\begin{array}{l}\text { Open-Loop Ground-Coupled } \\
\text { Heat Pump System }\end{array}$ & 12.3 & 1 & 56279 \\
\hline Alternative & Security Facility & $\begin{array}{c}\text { Propane Conventional Boiler / Electric } \\
\text { Package Unit }\end{array}$ & $\begin{array}{l}\text { Open-Loop Ground-Coupled } \\
\text { Heat Pump System }\end{array}$ & 8.3 & 1.8 & 42456 \\
\hline Appropriated & Security Facility & $\begin{array}{c}\text { Distillate Oil Conventional Boiler / } \\
\text { Electric Package Unit }\end{array}$ & $\begin{array}{l}\text { Open-Loop Ground-Coupled } \\
\text { Heat Pump System }\end{array}$ & 11 & 1.2 & 65284 \\
\hline Appropriated & Security Facility & $\begin{array}{c}\text { Propane Conventional Boiler / Electric } \\
\text { Package Unit }\end{array}$ & $\begin{array}{l}\text { Open-Loop Ground-Coupled } \\
\text { Heat Pump System }\end{array}$ & 8 & 2 & 49250 \\
\hline Alternative & Security Facility & $\begin{array}{c}\text { Propane Conventional Boiler / Electric } \\
\text { Package Unit }\end{array}$ & $\begin{array}{c}\text { Horizontal Closed-Loop } \\
\text { Ground-Coupled Heat Pump } \\
\text { System }\end{array}$ & 13.5 & 1.1 & 72842 \\
\hline Appropriated & Security Facility & $\begin{array}{c}\text { Propane Conventional Boiler / Electric } \\
\text { Package Unit }\end{array}$ & $\begin{array}{c}\text { Horizontal Closed-Loop } \\
\text { Ground-Coupled Heat Pump } \\
\text { System }\end{array}$ & 12.8 & 1.2 & 84497 \\
\hline Alternative & $\begin{array}{l}\text { Limited use Training } \\
\text { Building }\end{array}$ & $\begin{array}{c}\text { Electric Conventional Furnace / Electric } \\
\text { Package Unit }\end{array}$ & $\begin{array}{l}\text { Open-Loop Ground-Coupled } \\
\text { Heat Pump System }\end{array}$ & 8.3 & 1.1 & 125046 \\
\hline Appropriated & $\begin{array}{l}\text { Limited use Training } \\
\text { Building }\end{array}$ & $\begin{array}{c}\text { Electric Conventional Furnace / Electric } \\
\text { Package Unit }\end{array}$ & $\begin{array}{l}\text { Open-Loop Ground-Coupled } \\
\text { Heat Pump System }\end{array}$ & 8.7 & 1.5 & 145054 \\
\hline Alternative & $\begin{array}{c}\text { Large Physical Fitness } \\
\text { Center }\end{array}$ & $\begin{array}{c}\text { Distillate 0il Conventional Boiler / } \\
\text { Electric Air-Cooled Chiller }\end{array}$ & $\begin{array}{l}\text { Open-Loop Ground-Coupled } \\
\text { Heat Pump System }\end{array}$ & 2.5 & 4.9 & 74426 \\
\hline Appropriated & $\begin{array}{l}\text { Large Physical Fitness } \\
\text { Center }\end{array}$ & $\begin{array}{c}\text { Distillate Oil Conventional Boiler / } \\
\text { Electric Air-Cooled Chiller }\end{array}$ & $\begin{array}{l}\text { Open-Loop Ground-Coupled } \\
\text { Heat Pump System }\end{array}$ & 2.5 & 5.7 & 86335 \\
\hline Alternative & $\begin{array}{l}\text { Large Physical Fitness } \\
\text { Center }\end{array}$ & $\begin{array}{c}\text { Distillate Oil Conventional Boiler / } \\
\text { Electric Air-Cooled Chiller }\end{array}$ & $\begin{array}{l}\text { Horizontal Closed-Loop } \\
\text { Ground-Coupled Heat Pump } \\
\text { System }\end{array}$ & 7.6 & 1.8 & 180868 \\
\hline Appropriated & $\begin{array}{l}\text { Large Physical Fitness } \\
\text { Center }\end{array}$ & $\begin{array}{l}\text { Distillate Oil Conventional Boiler / } \\
\text { Electric Air-Cooled Chiller }\end{array}$ & $\begin{array}{c}\text { Horizontal Closed-Loop } \\
\text { Ground-Coupled Heat Pump } \\
\text { System }\end{array}$ & 7.3 & 2 & 209807 \\
\hline Alternative & $\begin{array}{l}\text { Large Physical Fitness } \\
\text { Center }\end{array}$ & $\begin{array}{c}\text { Distillate Oil Conventional Boiler } \\
\text { Electric Air-Cooled Chiller }\end{array}$ & $\begin{array}{c}\text { Vertical Closed-Loop } \\
\text { Ground-Coupled Heat Pump } \\
\text { System }\end{array}$ & 11 & 1.2 & 281112 \\
\hline Appropriated & $\begin{array}{l}\text { Large Physical Fitness } \\
\text { Center }\end{array}$ & $\begin{array}{c}\text { Distillate Oil Conventional Boiler } \\
\text { Electric Air-Cooled Chiller }\end{array}$ & $\begin{array}{c}\text { Vertical Closed-Loop } \\
\text { Ground-Coupled Heat Pump } \\
\text { System }\end{array}$ & 10.7 & 1.4 & 326089 \\
\hline Alternative & $\begin{array}{c}\text { Large Physical Fitness } \\
\text { Center }\end{array}$ & $\begin{array}{c}\text { Distillate Oil Conventional Boiler / } \\
\text { Electric Air-Cooled Chiller }\end{array}$ & $\begin{array}{l}\text { Open-Loop Ground-Coupled } \\
\text { Heat Pump System }\end{array}$ & 5.8 & 2 & 49012 \\
\hline Appropriated & $\begin{array}{c}\text { Large Physical Fitness } \\
\text { Center }\end{array}$ & $\begin{array}{c}\text { Distillate Oil Conventional Boiler } \\
\text { Electric Air-Cooled Chiller }\end{array}$ & $\begin{array}{l}\text { Open-Loop Ground-Coupled } \\
\text { Heat Pump System }\end{array}$ & 4.4 & 3.2 & 56854 \\
\hline Appropriated & $\begin{array}{l}\text { Large Physical Fitness } \\
\text { Center }\end{array}$ & $\begin{array}{l}\text { Distillate Oil Conventional Boiler / } \\
\text { Electric Air-Cooled Chiller }\end{array}$ & $\begin{array}{c}\text { Horizontal Closed-Loop } \\
\text { Ground-Coupled Heat Pump } \\
\text { System }\end{array}$ & 11.6 & 1.2 & 150329 \\
\hline Appropriated & $\begin{array}{l}\text { Large Physical Fitness } \\
\text { Center }\end{array}$ & $\begin{array}{c}\text { Distillate Oil Conventional Boiler } \\
\text { Electric Air-Cooled Chiller }\end{array}$ & $\begin{array}{c}\text { Vertical Closed-Loop } \\
\text { Ground-Coupled Heat Pump } \\
\text { System }\end{array}$ & 13.2 & 1.1 & 176577 \\
\hline Alternative & $\begin{array}{c}\text { Small Physical Fitness } \\
\text { Centers }\end{array}$ & $\begin{array}{c}\text { Distillate Oil Conventional Boiler } \\
\text { Electric Air-Cooled Chiller }\end{array}$ & $\begin{array}{l}\text { Open-Loop Ground-Coupled } \\
\text { Heat Pump System }\end{array}$ & 5.6 & 2.1 & 83754 \\
\hline Alternative & $\begin{array}{c}\text { Small Physical Fitness } \\
\text { Centers }\end{array}$ & $\begin{array}{c}\text { Propane Conventional Boiler / Electric } \\
\text { Air-Cooled Chiller }\end{array}$ & $\begin{array}{l}\text { Open-Loop Ground-Coupled } \\
\text { Heat Pump System }\end{array}$ & 10.7 & 1.3 & 40437 \\
\hline Appropriated & $\begin{array}{c}\text { Small Physical Fitness } \\
\text { Centers }\end{array}$ & $\begin{array}{c}\text { Distillate Oil Conventional Boiler / } \\
\text { Electric Air-Cooled Chiller }\end{array}$ & $\begin{array}{l}\text { Open-Loop Ground-Coupled } \\
\text { Heat Pump System }\end{array}$ & 3.5 & 4.1 & 97155 \\
\hline
\end{tabular}




\begin{tabular}{|c|c|c|c|c|c|c|}
\hline $\begin{array}{l}\text { Funding } \\
\text { Source }\end{array}$ & Building Set Description & Current Heating and Cooling Technology & Retrofit Technology & $\begin{array}{l}\text { Payback } \\
\text { Period }\end{array}$ & SIR & $\begin{array}{l}\text { Installed } \\
\text { Capital } \\
\text { Cost }(\$)\end{array}$ \\
\hline Appropriated & $\begin{array}{c}\text { Small Physical Fitness } \\
\text { Centers }\end{array}$ & $\begin{array}{c}\text { Propane Conventional Boiler / Electric } \\
\text { Air-Cooled Chiller }\end{array}$ & $\begin{array}{l}\text { Open-Loop Ground-Coupled } \\
\text { Heat Pump System }\end{array}$ & 7.6 & 2.1 & 46906 \\
\hline Alternative & $\begin{array}{l}\text { Small Physical Fitness } \\
\text { Centers }\end{array}$ & $\begin{array}{l}\text { Distillate Oil Conventional Boiler / } \\
\text { Electric Air-Cooled Chiller }\end{array}$ & $\begin{array}{c}\text { Horizontal Closed-Loop } \\
\text { Ground-Coupled Heat Pump } \\
\text { System }\end{array}$ & 11 & 1.1 & 156104 \\
\hline Alternative & $\begin{array}{l}\text { Small Physical Fitness } \\
\text { Centers }\end{array}$ & $\begin{array}{c}\text { Propane Conventional Boiler / Electric } \\
\text { Air-Cooled Chiller }\end{array}$ & $\begin{array}{c}\text { Horizontal Closed-Loop } \\
\text { Ground-Coupled Heat Pump } \\
\text { System } \\
\end{array}$ & 6.9 & 2 & 28300 \\
\hline Appropriated & $\begin{array}{c}\text { Small Physical Fitness } \\
\text { Centers }\end{array}$ & $\begin{array}{c}\text { Distillate Oil Conventional Boiler } \\
\text { Electric Air-Cooled Chiller }\end{array}$ & $\begin{array}{c}\text { Horizontal Closed-Loop } \\
\text { Ground-Coupled Heat Pump } \\
\text { System }\end{array}$ & 6.5 & 2.2 & 181081 \\
\hline Appropriated & $\begin{array}{l}\text { Small Physical Fitness } \\
\text { Centers }\end{array}$ & $\begin{array}{c}\text { Propane Conventional Boiler / Electric } \\
\text { Air-Cooled Chiller }\end{array}$ & $\begin{array}{c}\text { Horizontal Closed-Loop } \\
\text { Ground-Coupled Heat Pump } \\
\text { System }\end{array}$ & 4.9 & 3.2 & 32828 \\
\hline Alternative & $\begin{array}{l}\text { Small Physical Fitness } \\
\text { Centers }\end{array}$ & $\begin{array}{c}\text { Distillate Oil Conventional Boiler } \\
\text { Electric Air-Cooled Chiller }\end{array}$ & $\begin{array}{c}\text { Vertical Closed-Loop } \\
\text { Ground-Coupled Heat Pump } \\
\text { System } \\
\end{array}$ & 11.6 & 1 & 168256 \\
\hline Alternative & $\begin{array}{l}\text { Small Physical Fitness } \\
\text { Centers }\end{array}$ & $\begin{array}{c}\text { Propane Conventional Boiler / Electric } \\
\text { Air-Cooled Chiller }\end{array}$ & $\begin{array}{c}\text { Vertical Closed-Loop } \\
\text { Ground-Coupled Heat Pump } \\
\text { System }\end{array}$ & 7.9 & 1.7 & 31889 \\
\hline Appropriated & $\begin{array}{l}\text { Small Physical Fitness } \\
\text { Centers }\end{array}$ & $\begin{array}{l}\text { Distillate Oil Conventional Boiler } \\
\text { Electric Air-Cooled Chiller }\end{array}$ & $\begin{array}{c}\text { Vertical Closed-Loop } \\
\text { Ground-Coupled Heat Pump } \\
\text { System }\end{array}$ & 7 & 2.1 & 195177 \\
\hline Appropriated & $\begin{array}{l}\text { Small Physical Fitness } \\
\text { Centers }\end{array}$ & $\begin{array}{c}\text { Propane Conventional Boiler / Electric } \\
\text { Air-Cooled Chiller }\end{array}$ & $\begin{array}{c}\text { Vertical Closed-Loop } \\
\text { Ground-Coupled Heat Pump } \\
\text { System }\end{array}$ & 5.6 & 2.8 & 36991 \\
\hline
\end{tabular}


D-20

Renewable Energy Opportunities at Dugway Proving Ground, UT Pacific Northwest National Laboratory, May 2010 


\section{APPENDIX E}

\section{Analysis of Solar Opportunities}


Renewable Energy Opp

Pacific Northwest National Laboratory, May 2010 


\section{Appendix E: Analysis of Solar Opportunities}

\section{Solar Technology}

There is a wide range of solar technologies and applications available for energy generation. Solar technologies can be classified by the specific technique used for converting solar energy into useful energy for direct use as a substitute for a conventional energy source. Solar energy is unique in that the sun's energy, or insolation, can be captured to provide electrical energy, heating energy (solar thermal), or a combination of both.

Solar technologies can be further categorized by their scale. Large-scale solar projects can be massive in scope with hundreds of collectors and an energy output expressed in hundreds of kilowatts. Smaller-scale projects, often at the building level, are also possible and may be more desirable because of land area limitations, aesthetics considerations, or for energy security. Certain solar technologies, like PV, can be either large-scale or small-scale, while technologies like solar hot water heating are only found at the building level. Thermal CSP projects are typically large-scale.

\section{Solar Electric}

Solar electric collectors are either photovoltaic (PV) arrays or concentrating solar arrays. There are three major PV array subcategories, as follows:

- Flat Panel. Arrays of PV modules mounted on racks either at ground level or on rooftops at a fixed angle. Generally, this angle is equal to the location's latitude.

- Axis-Tracking. PV arrays can be mounted on an assembly that moves throughout the day and keeps the array positioned at an optimum angle to maximize the captured sunlight (Figure E-

1). An axis-tracking system can be either single- or dual-axis in nature. A singleaxis tracking system typically has a fixed tilt that elevates the panel off the ground by an angle and the system follows the sun's trajectory across the sky. These systems are able to collect more sunlight than nontracking systems. A dual-axis tracking system allows the panels to rotate along two axes, which maximizes the panel's ability to harvest solar energy. However, these systems are more complex and impose additional operations and maintenance costs compared to flat panel assemblies.

- Integrated PV Panel. PV panels can also be integrated with building roofing material, which can provide a cleaner look

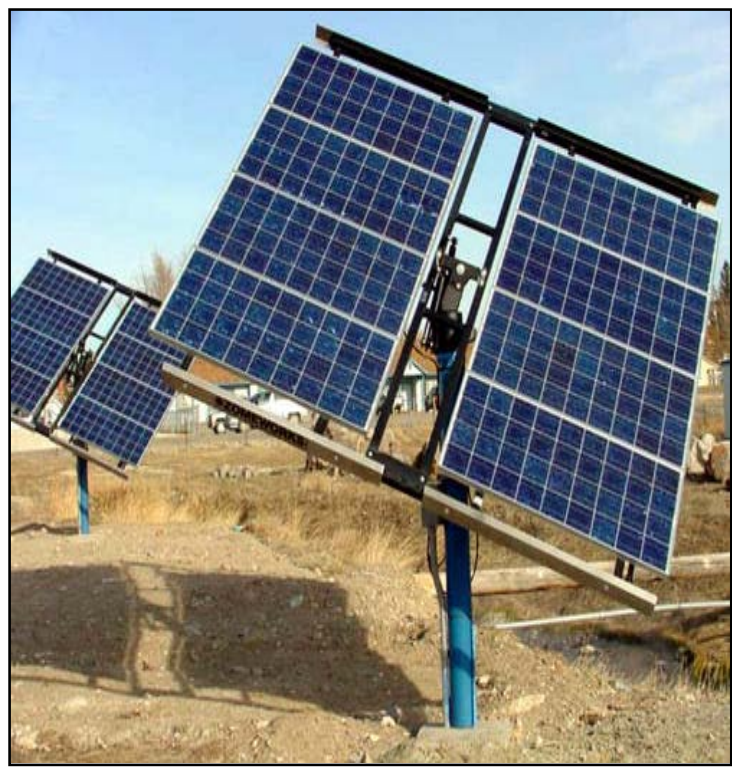

Figure E-1: Dual-Axis Tracking PV Array than stand-alone panels. Integrated PV panels can come as replacements for standard shingles, metal standing-seam roofing, and membrane roofing for flat roofs (Figure E-2). The lack of tilt usually prevents the system from optimizing its electricity generation. However, the lower capital costs of these systems can make them more cost-effective than 
other PV systems. One problem with roof-mounted systems is that the panels can be easily obscured by snow or other detritus unless they are regularly cleaned.

Concentrating solar power (CSP) systems use mirrors, lenses, and other optical devices to concentrate the sun's energy onto a receiver. The high temperatures generated by the focused sunlight can then be used for energy production. There are three primary configurations of thermal CSP systems:

- Solar Dish. A solar dish system employs an engine that is able to harvest thermal energy to generate electricity. These dual-axis tracking systems use dish-like

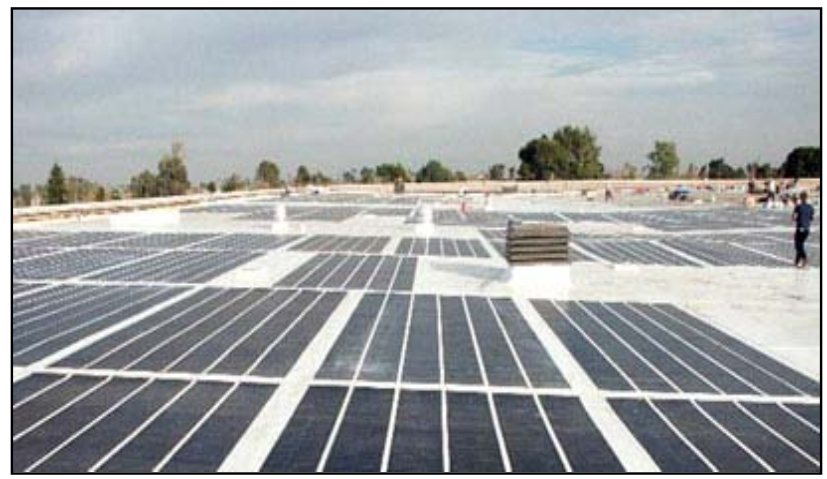

Figure E-2: Integrated PV on Rooftop concentrators to focus thermal energy on a point where a heat engine is mounted. Stirling engines are frequently used in solar dish applications (Figure E-3). Most systems are several kilowatts to tens of kilowatts.

- Solar Power Tower. A solar power tower system uses very large arrays of mirrors, or heliostats, to concentrate the sun's energy on a central receiver tower to produce steam that drives a generator. Thermal storage allows the system to store excess thermal energy for use at dusk and into the evening. Most existing or planned commercial solar power tower plants are larger than 10 MW.

- Solar Trough. When used for power generation, these large arrays concentrate the sun's energy onto a pipe containing a liquid that is used to

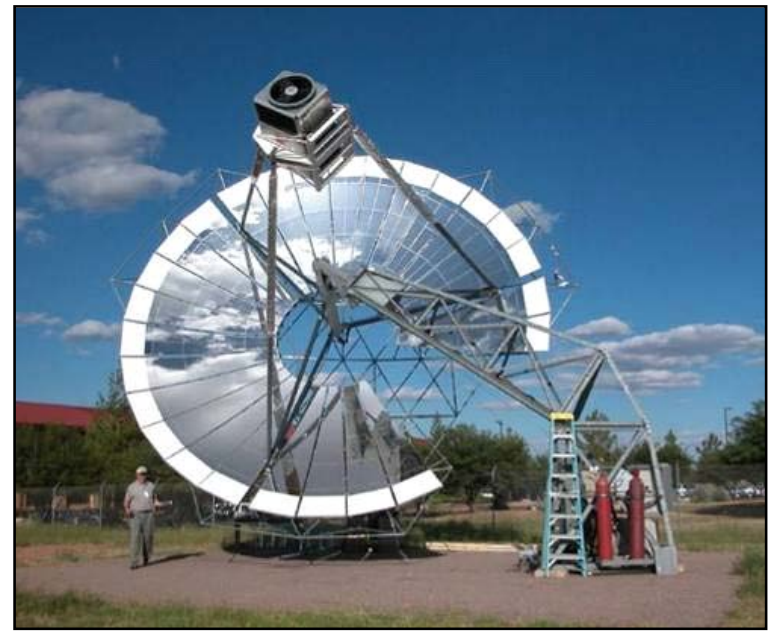

Figure E-3: Fort Huachuca Stirling Engine Solar Dish generate steam that drives a generator. These systems use single-axis tracking mirrors or reflectors orientated along the north-south axis and are sensitive to the slope of the ground as a result of the need to pump the liquid through the collector tubes. Cogeneration and thermal storage are options for this technology as well. Solar trough plants are $40 \mathrm{MW}$ or larger.

Thermal CSP plants are still in various stages of development. In general, solar trough plants are the most advanced, while the solar dish and solar power tower systems are less mature. While thermal CSP plants are somewhat unproven compared to traditional PV plants, they have the potential to deliver large quantities of energy at a cost below that of PV. Thermal concentrating power systems were not considered for this assessment because the available direct normal insolation is not close to the $6.75 \mathrm{kWh} / \mathrm{m}^{2} /$ day threshold for CSP feasibility. Direct normal insolation is a subset of the total insolation levels that excludes the indirect (diffuse) insolation, which is reflected from clouds or the ground, because this insolation cannot be concentrated. Based on data from the National Air and Space Administration's (NASA) Surface Meteorology and Solar Energy (SSE) Database, Dugway 
Proving Ground has an average direct normal insolation level of $5.69 \mathrm{kWh} / \mathrm{m}^{2} /$ day, which is below the $6.75 \mathrm{kWh} / \mathrm{m}^{2} /$ day target.

Lastly, concentrating PV (CPV) is beginning to gain attention as well. In a CPV system, mirrors and/or lens focus sunlight onto a small area of PV material. Typically, this PV material is more sophisticated and costly than the PV material used in most conventional solar cells. However, these advanced PV cells are also more efficient and are capable of absorbing insolation levels equivalent to dozens to hundreds of suns. This technology is promising because it may lead to low-cost solar energy as a result of reduced system materials cost. While there are a several commercial, smallscale CPV arrays and a handful of medium-scale utility demonstration projects, this technology is still too immature at this time.

\section{Solar Thermal \& Daylighting}

Rather than electricity as the end product, solar energy can also be used to directly heat air in the form of transpired solar collectors (i.e., solar walls), water that is used for space heating, or water that is used for service hot water (SHW) or swimming pools. These solar energy systems can be costcompetitive even when PV is not. However, solar thermal projects do not count towards the EPAct mandate.

Daylighting fixtures are also becoming an increasingly important part of energy management. Modern versions of traditional skylights have better insulating properties and light dispersion. Light shelves, atriums, and solar tubes are other examples of daylighting fixtures. Again, these are solarbased systems that can offset electricity consumption when properly implemented, but they do not generate electricity themselves. Although daylighting retrofits can be economic, daylighting is most cost-effective when implemented during a building's planning phase. Like the above-mentioned solar thermal technologies, daylighting technologies do not count towards the EPAct mandate.

\section{Existing Solar Projects}

There are no substantial PV projects at Dugway Proving Ground at this time.

\section{Solar Analysis Approach}

The analytic approach for the solar energy assessment consists of the following steps:

- Identify solar potential-Use established sources to determine seasonal and annual solar radiation for the site.

- $\quad$ Determine utility perspective-Obtain electric rate tariff information, evaluate state and local regulations, and identify grants, incentives, and other support.

- Identify potential development areas-Study existing electrical transmission system and identify installation-specific sites and potential users of generated energy.

- Determine applicable solar technology — Evaluate solar electric technologies including both large-scale (approximately $500 \mathrm{~kW}$ to 5+ MW) applications, such as an array of groundmounted PV panels, and small-scale (30 kW to $500 \mathrm{~kW}$ ) applications, such as roof-mounted PV systems.

- $\quad$ Develop project economics-Determine project capital investment requirements, project operations and maintenance costs, and estimate economic value of expected electric production based on selected solar technology and market prices. 


\section{Solar Resource Characterization}

Utah's average insolation levels are between 4.5 to $6.0 \mathrm{kWh} / \mathrm{m}^{2} /$ day. Although Dugway Proving Ground is located in a valley that slightly impacts its access to solar insolation, the site is still relatively well positioned to take advantage of the solar resource (Figure E-4: note that this map displays global insolation and not direct normal insolation).

The solar resource potential was estimated using the National Air and Space Administration's (NASA) Surface Meteorology and Solar Energy (SSE) data and Natural Resources Canada's RETScreen analysis software. The SSE data set is a continuous and consistent 10-year global climatology of insolation and meteorology data on a $1^{\circ}$ by $1^{\circ}$ grid system. Although the SSE data within a particular grid cell are not necessarily representative of a particular microclimate or point within the cell, the data are considered to be the average over the entire area of the cell. That estimate should be sufficiently accurate for preliminary feasibility studies of new renewable energy projects. In addition, the SSE database provides year-to-year variability in terms of 10year maximums and minimums for a number of parameters.

In Table E-1, the average solar insolation data is shown for several different surface orientations including: a flat roof surface, a flat panel with a

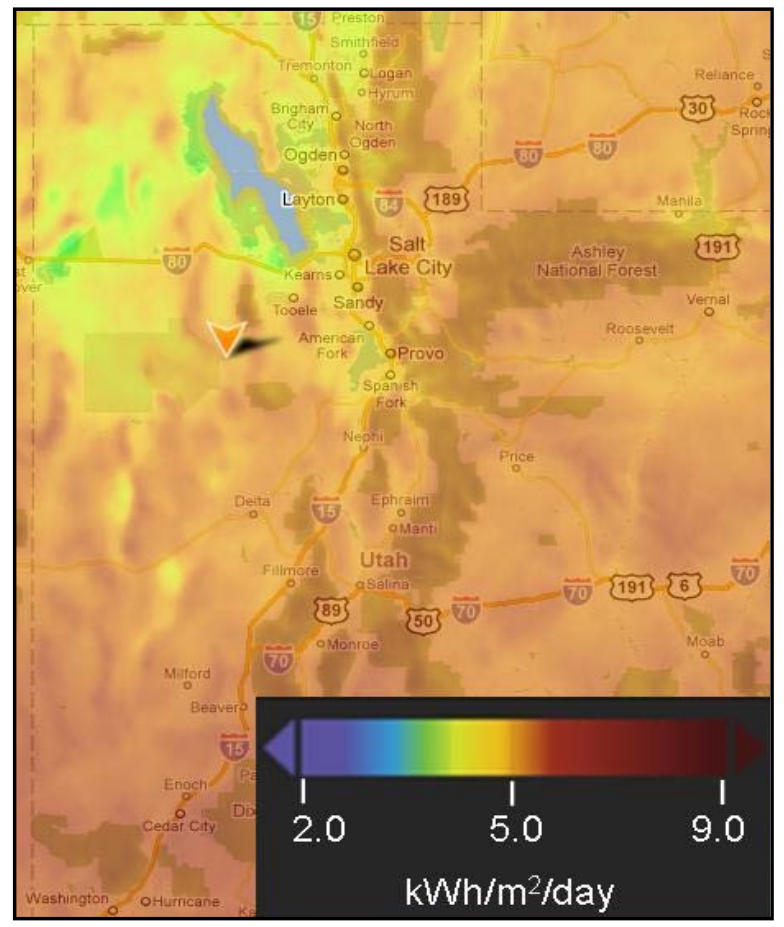

Figure E-4: Solar Insolation Levels, 3Tier FirstLook Solar Resource Map tilt equal to the latitude, a dual-axis tracking panel, a flat, wall-mounted panel, and direct normal insolation. Average monthly insolation values are provided in $\mathrm{kWh} / \mathrm{m}^{2} /$ day for the following conditions:

- Tilt 0 - Collector installed at a $0^{\circ}$ tilt (i.e., on a flat surface such as a roof)

- Tilt (lat-15) - A tilt of latitude minus $15^{\circ}$ would favor energy production in the summer when the sun is higher

- $\quad$ Tilt lat - Tilting a PV array at an angle equal to the latitude is a generally accepted way to optimize annual electricity production

- Tilt (lat+15) - A tilt of latitude plus $15^{\circ}$ would favor energy production in the winter when the sun is lower

- $\quad$ Tilt 90 - Collector installed against a vertical surface (i.e., wall)

- Dual-Axis Tracking - Collector capable of tracking the sun's zenith and azimuth angle over the course of the day, thereby maximizing its insolation value.

- Direct Normal Insolation - This is the amount of direct insolation that directly strikes a surface that tracks the sun. This parameter is important for concentrating solar power systems. 
Table E- 1: Monthly Averaged Insolation Incident on an Equator-Pointed Tilted Surface at Dugway Proving Ground (kWh/m²lday)

\begin{tabular}{||l|c|c|c|c|c|c|c|c|c|c|c|c|c||}
\hline \hline & Jan & Feb & Mar & Apr & May & Jun & Jul & Aug & Sep & Oct & Nov & Dec & $\begin{array}{c}\text { Annual } \\
\text { Average }\end{array}$ \\
\hline Tilt 0 & 1.94 & 2.91 & 4.11 & 5.4 & 6.51 & 7.36 & 7.33 & 6.51 & 5.23 & 3.7 & 2.24 & 1.69 & 4.58 \\
\hline Tilt 25 & 2.92 & 3.91 & 4.87 & 5.77 & 6.44 & 7.03 & 7.11 & 6.76 & 6.03 & 4.82 & 3.29 & 2.62 & 5.13 \\
\hline Tilt 40 & 3.32 & 4.22 & 4.99 & 5.60 & 6.00 & 6.42 & 6.55 & 6.45 & 6.08 & 5.14 & 3.67 & 3.00 & 5.12 \\
\hline Tilt 55 & 3.55 & 4.31 & 4.85 & 5.16 & 5.28 & 5.51 & 5.67 & 5.82 & 5.81 & 5.18 & 3.85 & 3.22 & 4.85 \\
\hline Tilt 90 & 3.36 & 3.62 & 3.63 & 3.30 & 2.96 & 2.86 & 3.00 & 3.47 & 4.09 & 4.21 & 3.45 & 3.05 & 3.42 \\
\hline $\begin{array}{l}\text { Dual Axis } \\
\text { Tracking }\end{array}$ & 4.18 & 5.14 & 6.31 & 7.71 & 8.69 & 9.73 & 9.90 & 9.39 & 7.99 & 6.26 & 4.56 & 3.78 & 6.97 \\
\hline $\begin{array}{l}\text { Direct } \\
\text { Normal } \\
\text { Insolation }\end{array}$ & 4.19 & 4.88 & 6.03 & 6.12 & 6.61 & 7.12 & 7.04 & 6.3 & 6.08 & 5.37 & 4.39 & 4.07 & 5.69 \\
\hline
\end{tabular}

The solar resource data for Dugway Proving Ground shown in Table E-1, shows that a flat collector tilted at $40^{\circ}$ (Tilt lat) has an average yearly solar potential of $5.12 \mathrm{kWh}_{\text {solar }} / \mathrm{m}^{2} /$ day. A dual-axis tracking PV array will receive $6.97 \mathrm{kWh}_{\text {solar }} / \mathrm{m}^{2} /$ day of incident solar radiation. Figure E-5 shows this incident solar radiation on a flat roof surface $\left(0^{\circ}\right.$ tilt), a fixed array (latitude tilt), a dual-axis tracking array, and a wall-mounted system ( $90^{\circ}$ tilt) at Dugway Proving Ground.

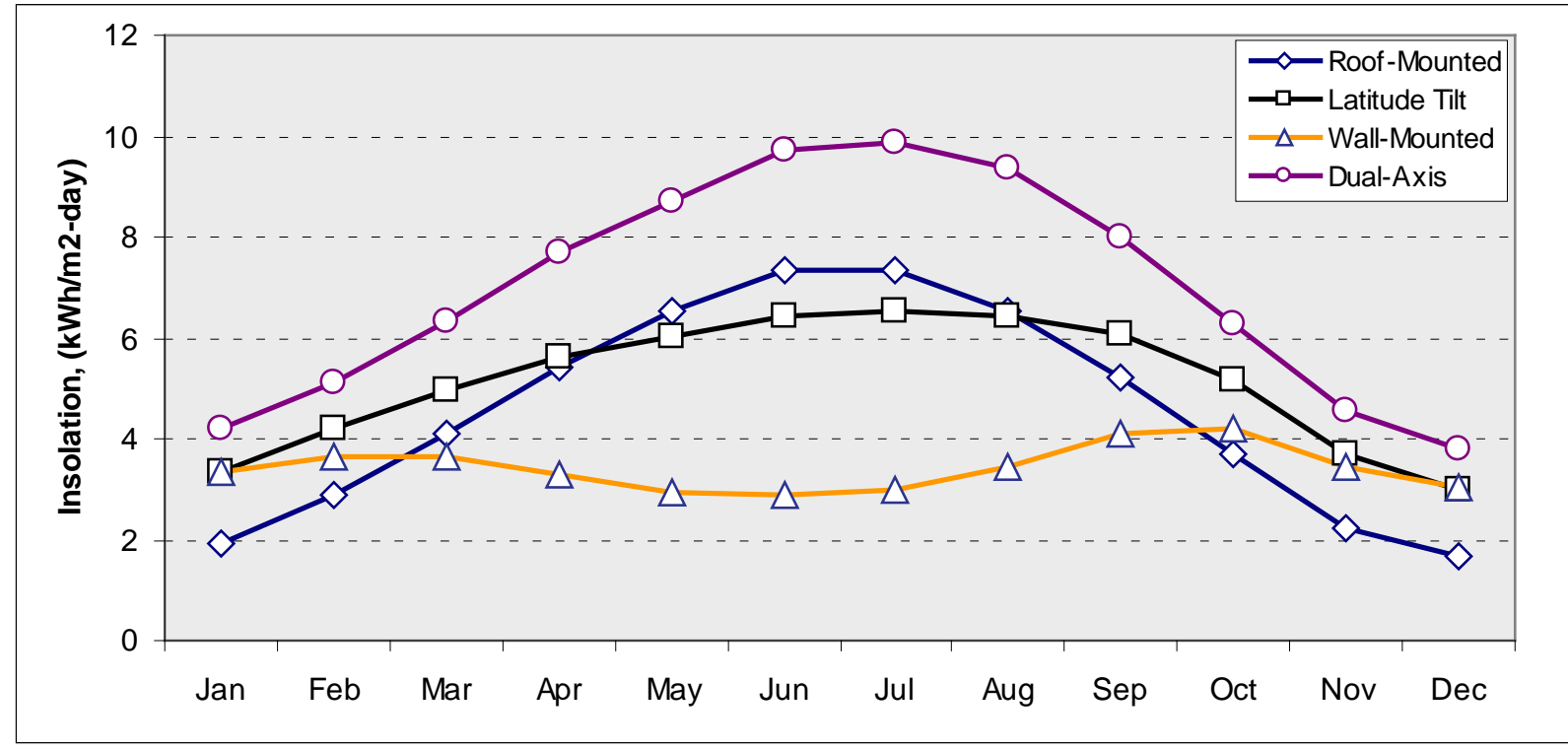

Figure E-5: Average Daily Insolation at Dugway Proving Ground

\section{Siting Considerations for Solar Technologies}

Compared to most renewable energy technologies, PV panels have a fair degree of siting flexibility. As previously mentioned, an array can be mounted on the ground or on existing buildings and structures. A potential site needs to be free of any objects, such as trees or buildings, which may cast a shadow on the array. Also, the system will require an inverter to convert the DC power output into AC power. Inverters can be located indoors or outdoors, although indoor locations will provide more shelter and help ensure inverter longevity and performance. For projects larger than $25 \mathrm{~kW}$, multiple 
inverters are used to optimize the system's efficiency as well as provide redundancy. If any projects of this scale were considered, space would need to be secured for the inverter bank.

A typical 1-kW PV array may range in size from 8 to $9 \mathrm{~m}^{2}$; however, a larger array requires access space as well as spacing between the rows of panels to avoid self-shading and will subsequently require a greater amount of space per installed $\mathrm{kW}$. For example, a 30-kW array would likely require $550 \mathrm{~m}^{2}$, and a $100-\mathrm{kW}$ array may require nearly $2000 \mathrm{~m}^{2}$, assuming that the PV array occupies $50 \%$ of the space. Panels mounted on slanted roofs can usually be more tightly grouped because of a decrease in self-shading potential. In addition, large arrays can produce considerable amounts of energy and require siting near existing high voltage power lines. Solar dish systems typically require $110 \mathrm{~m}^{2}$ per dish and can be sited in a wide variety of locations provided there are no shade-casting objects and there is access to power lines.

Roof-integrated PV systems are ideal when there is only a minimal amount of available ground space or when a building's roof is in need of replacement. Although roof-sited PV systems frequently require the installation of PV panels at non-optimized angles because of roof slopes and orientations, roof-integrated PV can be an attractive option because of its relatively low cost and its ability to securely generate energy for mission-critical buildings.

Dugway Proving Ground appears to have abundant open space for ground-mounted arrays. Possible sites that appear to have sufficient open space and are relativity free from shading include:

- In the area near substation 1 off a $12.47-\mathrm{kV}$ line in English Village

- In the area near substation 2 off a $12.47-\mathrm{kV}$ line in the Ditto Area

- In the area near substation 3 off a 12.47-kV line between Ditto and English Village.

There are additional spaces spread throughout Dugway Proving Ground that are also near high voltage lines. The terrain is generally flat and would require minimal grading. The primary disadvantages of these areas is their distance from the main post and testing areas, which will increase travel and construction time as well as potential mission impact. The abundance of available space near the cantonment area and the primary testing areas suggests that considering more remote areas will not be necessary.

\section{Findings: Solar Electric Production}

A flat collector tilted at an angle equal to the latitude $\left(40^{\circ}\right)$ has an average yearly solar potential of $5.12 \mathrm{kWh}_{\text {solar }} / \mathrm{m}^{2} /$ day at Dugway Proving Ground. Solar conversion can be an inefficient process; typical PV cells have a conversion efficiency ranging from $10 \%$ to $20 \%$. Whereas solar potential is expressed in $\mathrm{kWh}_{\text {solar }} / \mathrm{m}^{2}$, PV array production is generally expressed as annual energy produced per rated $1 \mathrm{~kW}$ of PV array. Taking into account the annual solar potential and the efficiency of a typical PV system, each fixed angle, latitude tilted $\mathrm{kW}$ of installed PV would be expected to produce 1,539 $\mathrm{kWh}_{\text {electric }}$ at Dugway Proving Ground. The system would have a capacity factor of $17.6 \%$.

An axis-tracking PV array can produce $30 \%$ to $40 \%$ more energy than a stationary PV array, resulting in a higher output per unit surface area, and has a much flatter energy output profile during the day. The tracking racks increase the cost of installation by approximately $\$ 1$ to $\$ 2$ per installed watt. An axis-tracking array would produce $2,083 \mathrm{kWh}_{\text {electric }}$ annually per $1 \mathrm{~kW}$ of installed PV capacity at Dugway Proving Ground. The system would have a capacity factor of $23.8 \%$. 
Building-integrated solar products such as standing seam roofs and integrated roof-membrane PV should be considered for new construction and major renovations where cost savings can be leveraged. For example, if a roof needs to be replaced, the replacement would be an avoided cost for the solar project. An integrated roof-membrane PV product installed on a flat roof at Dugway Proving Ground would be expected to produce $1.411 \mathrm{kWh}_{\text {electric }}$ annually per $1 \mathrm{~kW}$ of installed capacity. The system would have a capacity factor of $16.1 \%$. Satellite imagery shows that the five largest viable roofs on post have approximately 4,300 square meters of open roof area that could host approximately $328 \mathrm{~kW}$ of integrated roof-membrane PV material, which would produce approximately $462 \mathrm{MWh}_{\text {electric }}$ annually.

Table E-2 lists the five large, viable (e.g., flat or nearly flat) building rooftops on Dugway Proving Ground considered in this study. It was assumed that only $50 \%$ of the rooftop space would be available for PV modules because of commonly encountered roof obstructions, such as HVAC systems or vents, the need to preserve access paths across the roof, and shading from nearby buildings, trees, and parapet walls.

Table E- 2: Roof-Integrated Membrane PV Analysis at Dugway Proving Ground

\begin{tabular}{||c|c|c|c||}
\hline $\begin{array}{l}\text { Building } \\
\text { Number }\end{array}$ & $\begin{array}{c}\text { Viable Roof } \\
\left.\text { Area } \mathbf{( m}^{\mathbf{2}}\right)\end{array}$ & $\begin{array}{c}\text { Potential Installed } \\
\text { Capacity (kW) }\end{array}$ & $\begin{array}{c}\text { Energy Output } \\
\text { (MWh/yr) }\end{array}$ \\
\hline $\mathbf{5 4 7 0}$ & 1,500 & 110 & 155 \\
\hline $\mathbf{4 5 3 1}$ & 1,400 & 105 & 148 \\
\hline $\mathbf{5 3 0 4}$ & 500 & 40 & 56 \\
\hline $\mathbf{4 2 2 3}$ & 490 & 40 & 56 \\
\hline $\mathbf{4 3 6 1}$ & 440 & 33 & 47 \\
\hline \hline Total & $\mathbf{4 , 3 3 0}$ & $\mathbf{3 2 8}$ & $\mathbf{4 6 2}$ \\
\hline
\end{tabular}

A summary of the solar electric production can be found in Table E-3.

Table E- 3: Solar Electric Production by System Type at Dugway Proving Ground

\begin{tabular}{|c|c|c|c|c|c|}
\hline System Type & $\begin{array}{l}\text { Assumed } \\
\text { PV Module } \\
\text { Efficiency }\end{array}$ & $\begin{array}{l}\text { Solar Insolation, } \\
\mathbf{k W h}_{(\text {solar) }} / \mathrm{m}^{2} / \mathbf{y r}\end{array}$ & $\begin{array}{c}\text { Electric } \\
\text { Production, } \\
\mathbf{k W h}_{\text {(electric) }} / \mathbf{y r}\end{array}$ & $\begin{array}{c}\text { Specific } \\
\text { Yield, } \\
\left(\mathbf{k W h} / \mathbf{m}^{2}\right)\end{array}$ & $\begin{array}{l}\text { Capacity } \\
\text { Factor }\end{array}$ \\
\hline $\begin{array}{c}1 \text { kW South-Facing, } \\
33^{\circ} \text { Tilt }\end{array}$ & $11.00 \%$ & 1,870 & 1,539 & 169.3 & $17.6 \%$ \\
\hline $\begin{array}{c}1 \mathrm{~kW} \text { Integrated Roof } \\
\text { Membrane }\end{array}$ & $7.60 \%$ & 1,670 & 1,411 & 107.3 & $16.1 \%$ \\
\hline $\begin{array}{c}1 \mathrm{~kW} \text { Dual-Axis } \\
\text { Tracking }\end{array}$ & $11.00 \%$ & 2,550 & 2,083 & 229.2 & $23.8 \%$ \\
\hline
\end{tabular}

\section{Findings: Solar Project Economics}

Based on current average solar system costs and the projected performance for the various solar system configurations, life-cycle costs were developed for solar technologies at Dugway Proving Ground under two funding scenarios: 
- Appropriated, using Energy Conservation Investment Program (ECIP) funds and,

- $\quad$ Third party financing via an independent power producer (IPP).

Cost-effectiveness for ECIP projects is determined with savings-to-investment ratio (SIR) values while the internal rate of return (IRR) shows whether the IPP scenario is cost-effective. Third-party financing utilizes a third-party to develop, fund, and install the projects under a power purchase agreement (PPA) or other vehicle. The third-party, being a private company or utility, could take advantage of tax credits for renewable energy projects and may also sell the renewable energy credits (RECs), which in turn lower the cost required to pay for the electricity. Building-integrated PV can also be developed by a third-party to take advantage of government incentives.

Dugway Proving Ground's energy sourcing is from Rocky Mountain Power. Solar arrays are not capable of providing base load power due to their intermittent nature. Moreover, because solar system energy production peaks during the daytime and is larger in the summer than in the winter, the energy produced by a solar system would vary over the year. To account for this variance, the Dugway Proving Ground electric rate was analyzed. The daytime and evening electricity prices, as well as the summer and winter electricity prices, were used to calculate a weighted average price of electricity with respect the solar insolation availability patterns. This weighted average was equal to $3.0 \mathrm{\$} / \mathrm{kWh}$, which is slightly higher than the $2.6 \mathrm{\$} / \mathrm{kWh}$ simple average marginal electric rate.

Despite the moderately strong solar resource, none of the solar systems are cost-effective at this time. The combination of low-cost energy and high system capital costs is the principal barrier to economic solar power generation at Dugway Proving Ground. The SIR and simple payback for the ECIP scenario, the cost of electricity at a 10\% IRR for the third-party financing scenario, and the breakeven system cost are shown in Table E-4 for each technology. Note, the cost of electricity at a $10 \%$ (internal rate of return) IRR is the cost of electricity that would be required to yield a $10 \%$ IRR at the assumed system prices. Utah's RPS allows solar energy to count as the equivalent of $2.4 \mathrm{kWh}$ of conventional energy. Using this conversion, RECs would need to be sold between $12.0 \$ / \mathrm{kWh}$ to $13.7 \$ / \mathrm{kWh}$. This value range is high for RECs, and it is unlikely that a buyer could be found given Utah's RPS. Lastly, a solar photovoltaic power plant could improve Dugway Proving Ground's energy security. Although it cannot provide base load power like geothermal and waste-to-energy power plants, a solar PV array output usually correlates well to an installations peak power demand.

This analysis assumed a 3.0\% real discount rate, a 1.8\% general inflation rate. The 3.0\% discount rate is a typical value used for net present value (NPV) calculation while the $1.8 \%$ general inflation rate is based upon national statistics. 
Table E- 4: Economic Results for Solar Technologies at Dugway Proving Ground

\begin{tabular}{||l|c|c|c||}
\hline & $\begin{array}{c}\text { Ground-Mounted } \\
\text { Fixed-Tilt PV }\end{array}$ & $\begin{array}{c}\text { Ground-Mounted } \\
\text { Axis-Tracking PV }\end{array}$ & $\begin{array}{c}\text { Building-Integrated } \\
\text { Roof-Mounted PV }\end{array}$ \\
\hline $\begin{array}{l}\text { Equipment Cost } \\
\text { Assumptions (\$/kW) }\end{array}$ & $\$ 6,450$ & $\$ 7,800$ & $\$ 5,550$ \\
\hline SIR & 0.083 & 0.103 & 0.084 \\
\hline Simple Payback (yr) & 160 & 130 & 33.8 \\
\hline $\begin{array}{l}\text { Cost of Electricity at } \\
\text { 10\% IRR (\$/kWh) }\end{array}$ & 35.9 & 32.0 & 0.00 \\
\hline Variable O\&M (c/kWh) & 0.00 & 0.00 & $\$ 12$ \\
\hline Fixed O\&M (\$/net kW) & $\$ 12$ & $\$ 12$ & \\
\hline
\end{tabular}

\section{Solar: Next Steps}

Dugway Proving Ground has a moderately high solar energy resource. Unfortunately, present project capital costs and current electric rates do not show independent solar energy projects to be cost-effective at Dugway Proving Ground at this time. Future rate increases and any changes to Utah's renewable portfolio standard that more aggressively requires utilities to invest in renewable energy technologies may eventually allow PV to be cost-effective. Dugway Proving Ground should continue to monitor the market conditions affecting solar energy. Advances in PV technology are expected to produce less expensive solar cells, although rising demand may negate some of the potential price drop. Probably the most important factor in making solar electric work at a Federal installation is identifying key partners - a private developer, a utility, or both - that can provide funding, capture tax incentives, purchase or market RECs, enter into PPAs, and provide other project support.

\section{Solar Sources of Information}

Department of Energy (DOE). 1997. "Renewable Energy Technology Characterizations - December 1997 - Solar Parabolic Trough.” http://www1.eere.energy.gov/ba /pba/pdfs/solar_trough.pdf. Accessed November 2008.

Department of Energy (DOE). 1997. "Renewable Energy Technology Characterizations - December 1997 - Solar Power Tower.” http://www1.eere.energy.gov/ba /pba/pdfs/solar_tower.pdf. Accessed November 2008.

Department of Energy (DOE). 1997. "Renewable Energy Technology Characterizations - December 1997 - Solar Dish Engine.” http://www1.eere.energy.gov/ba /pba/pdfs/solar_dish.pdf. Accessed November 2008.

Emerging Energy Research, LTD. November 2007. “Global Concentrating Solar Power Markets and Strategies, 2009-2020.” Cambridge, Massachusetts.

Lawrence Berkeley National Laboratory, February 2009. “Tracing the Sun: The Installed Cost of Photovoltaics in the U.S. from 1998-2007.” Berkeley, California.

Minister of Natural Resources Canada. 1997-2008. RETscreen International Software Package, Clean Energy Decision Support Centre. http://www.retscreen.net. Accessed November 2009. 
Sargent \& Lundy Consulting Group. 2003. “Assessment of Parabolic Trough and Power Tower Solar Technology Cost and Performance Forecasts.” Golden, Colorado.

Stoddard L, J Abiecunas, and R O'Connell. 2006. “Economic, Energy, and Environmental Benefits of Concentrating Solar Power in California.” Black \& Veatch \& National Renewable Energy Laboratory. Overland Park, KS. NREL/SR-550-39291. 
APPENDIX F

Analysis of Wind Opportunities 
Renewable Energy Opportunities at Dugway Proving Ground, Utah Pacific Northwest National Laboratory, May 2010 


\section{Appendix F: Analysis of Wind Opportunities}

There is a vast wind resource in the United States. The American Wind Energy Association states that domestic wind resources, which are economically feasible in at least 46 states, could theoretically supply all of the nation's electricity needs. At the current time, however, less than $1 \%$ of the nation's power is generated from wind. This situation is changing. In 2005 and 2006, wind was the second largest source of new electricity generation in the United States (AWEA 2007). In 2007, wind energy projects accounted for $30 \%$ of all the new energy capacity installed nationally (AWEA 2008).

Wind projects, often referred to as wind farms, can be categorized by scale. Large, utilityscale projects tend to be $50 \mathrm{MW}$ and above, with the world's largest single wind farm being in Texas at over $700 \mathrm{MW}$. Smaller projects (under $50 \mathrm{MW}$ ) are referred to as community wind projects or distributed generation (DG) projects. Community wind projects involve local ownership structures, often with corporate partners taking advantage of the Federal production tax credit. DG projects are designed to offset the owner's retail electricity purchases by producing power that is used on-site, with surplus sold to a commercial utility.

Wind turbines come in many different sizes and configurations. Wind turbines in the U.S. generally employ the Danish configuration - a horizontal-axis, three-bladed rotor, an upwind orientation, and an active yaw system to keep the rotor oriented into the wind.

Utility-scale turbines for bulk power production tend to be $660 \mathrm{~kW}$ to $3 \mathrm{MW}$ in size. Hub heights can range from 50 meters (164 feet) to 80 meters (262 feet). Industrial turbines for consumer and remote grid production are found in the range of $50 \mathrm{~kW}$ to $250 \mathrm{~kW}$. Hub heights range between 25 meters ( 80 feet) and 40 meters (131 feet). Residential-scale wind turbines are used for remote power, battery charging, or net-metering generation. These turbines tend to be 400 watts to $50 \mathrm{~kW}$. For turbines greater than $1 \mathrm{~kW}$, the hub heights range from 12 meters (40 feet) to 36 meters (120 feet).

The land required for a single utility-scale wind turbine is typically 3 acres, including access roads, turbine base, and other equipment. A wind turbine located on a ridgeline in hilly terrain will require less area than one on flat land, as little as 2 acres per MW. The proper spacing of turbines is essential to reduce wake interference and optimize the wind resource. In open flat terrain, a utility-scale wind plant will require a buffer space of about 60 acres per MW of installed capacity.

Although more difficult to finance and lacking in economies of scale, smaller wind generation projects offer some potential benefits over large-scale wind farms:

- A smaller project is often easier to permit and may be less likely to interfere with other land uses (including military missions).

- On-site power generation that is integrated into the site electrical system provides energy security.

- It may be possible to avoid building a costly substation if a suitably sized power interconnection is located near a promising site for wind turbines. 


\section{Wind Analysis Approach}

\section{DoD Assessment Approach}

The DoD Renewables Study relied upon wind resource maps developed by the National Renewable Energy Laboratory (NREL), maps developed by independent companies, and PNNL's Wind Energy Resource Atlas of the United States to identify the installations with best potential for commercial-scale wind farms. The DoD analysis used the highest resolution map available for each state to quantify the wind resource on the military land in that state. Over 70 Army and Air Force installations were reviewed with respect to both wind resource and compatibility with the installation's mission. About 20 installations with potential for projects were selected for follow-on detailed assessments. Dugway Proving Ground was not included in this original study.

\section{Updated Wind Analysis Approach}

For this updated analysis, PNNL used the following approach to analyze the economic potential for wind energy at Dugway Proving Ground. More detail on the financing scenarios, generic analytic approach, and economic and other parameters used in this analysis are documented in Appendix A of this report.

(1) Wind resource maps were analyzed.

(2) Existing on-site interconnection and transmission capacity and availability were evaluated.

(3) Local wind developer activity in the area was surveyed to assess potential interest in developing projects.

(4) Available turbine models were evaluated to establish cost and performance parameters.

(5) Total project cost was estimated, including project development, generation equipment, balance of plant construction, interconnection and transmission, operation and maintenance (O\&M), taxes, and tax credits and other policy incentives.

(6) Economic feasibility was determined utilizing different financing scenarios: independent power producer (IPP) and Energy Conservation Investment Program (ECIP).

(7) Project feasibility was determined and next steps recommended.

\section{Wind Resource Characterization}

According to industry standards developed as part of the Wind Energy Resource Atlas of the United States, there are seven main classes of wind power, as shown in Table F-1. 
Table F- 1: Classes of Wind Power Density at 50 Meters

\begin{tabular}{||c|c|c||}
\hline $\begin{array}{c}\text { Wind } \\
\text { Power } \\
\text { Class }\end{array}$ & $\begin{array}{c}\text { Wind Power } \\
\text { Density, } \\
\text { W/m }\end{array}$ & Speed, m/s (mph) \\
\hline $\mathbf{1}$ & $<200$ & $<5.6(12.5)$ \\
\hline $\mathbf{2}$ & $200-300$ & $5.6(12.5)-6.4(14.3)$ \\
\hline $\mathbf{3}$ & $300-400$ & $6.4(14.3)-7.0(15.7)$ \\
\hline $\mathbf{4}$ & $400-500$ & $7.0(15.7)-7.5(16.8)$ \\
\hline $\mathbf{5}$ & $500-600$ & $7.5(16.8)-8.0(17.9)$ \\
\hline $\mathbf{6}$ & $600-800$ & $8.0(17.9)-8.8(19.7)$ \\
\hline $\mathbf{7}$ & $>800$ & $>8.8(19.7)$ \\
\hline
\end{tabular}

A strong Class 3 resource, preferably Class 4, is generally required to achieve an economic project on a large, commercial scale. According to the DoE's Utah Wind Resource Map, Dugway Proving Ground has a Class 2 wind resource. A Class 2 wind resource is generally not sufficient to support a large-scale wind energy project.

To determine an average annual wind speed estimate for Dugway Proving Ground, the windNAVIGATOR wind mapping tool from AWS Truewind was used. At 80 meters above ground, a typical hub height for commercial-scale turbines, the highest average annual wind speed found on-site is 6.46 m/s (AWS Truewind 2009), as shown in Figure F-1.

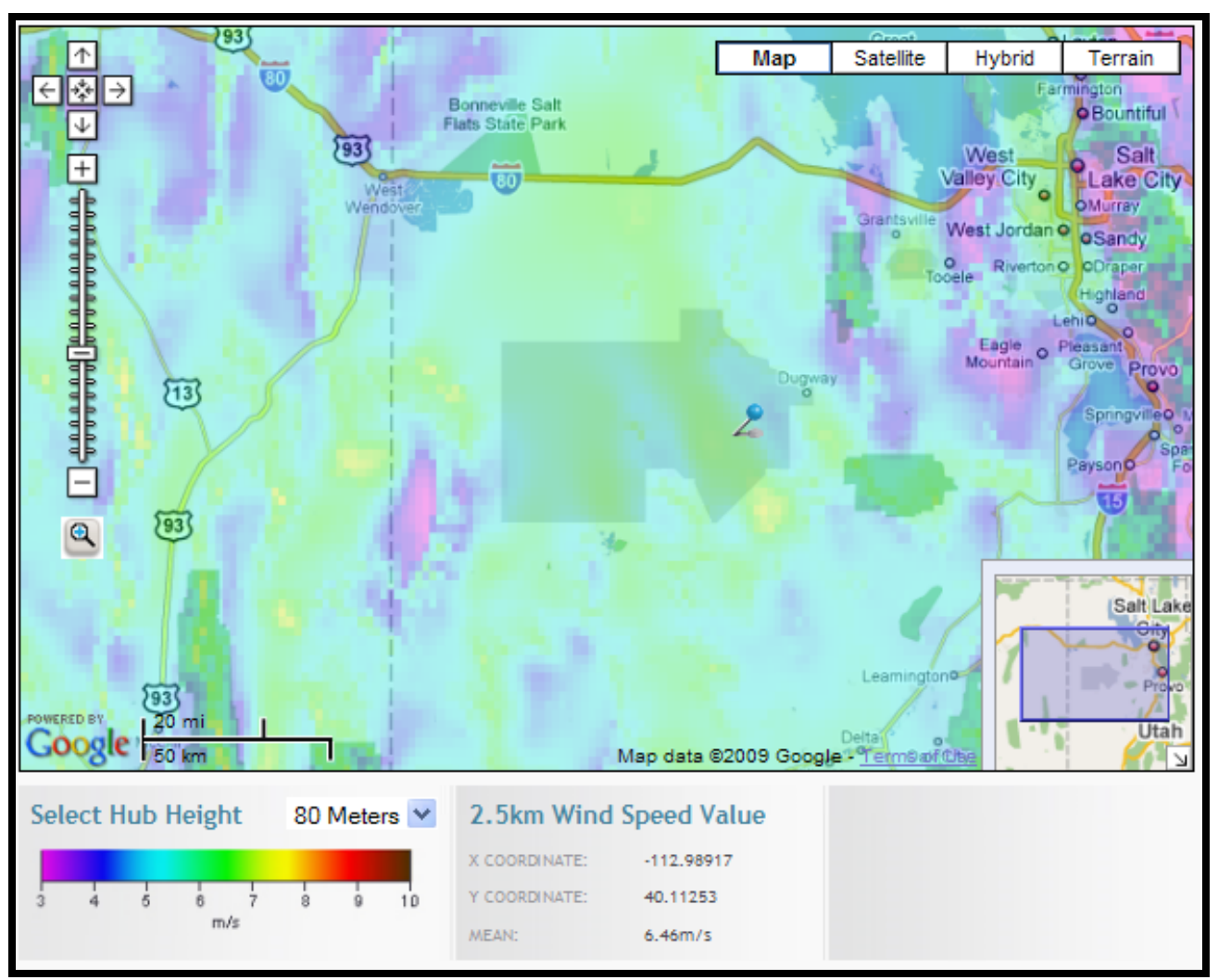

Figure F- 1: Highest Wind Speed on Dugway Proving Ground 
The ridgelines and peaks in the areas of Simpson Buttes, Camel's Back Ridge, Granite Peak, and Wig Mountain appear to have the best wind resource on-site, but are also at high elevations $-4,000$ to 7,000 feet. The constructability and accessibility of these areas needs to be examined to determine their suitability for meteorological tower ("met tower") and wind turbine placement. These high elevation and high wind resource areas are indicated by the yellowish color in Figure F-1.

NASA’s Langley Research Center Atmospheric Science Data Center was used as a reference comparison for Dugway Proving Ground's average wind speed. NASA Surface Meteorology and Solar Energy (SSE) provides data on a $1^{\circ}$ by $1^{\circ}$ grid system, based on wind speed data over a 10-year period from July 1983 to June 1993. According to this source, the annual average wind speed in the Dugway Proving Ground area is $5.17 \mathrm{~m} / \mathrm{s}$ at 50 meters (NASA 2008). Because this average wind speed is calculated for a large amount of land, the average is lower than what could be found at a given, specific location. Table F-2 summarizes Dugway Proving Ground's wind resource.

Table F- 2: Summary of Wind Resource Data

\begin{tabular}{|c|l|l||}
\hline Location & \multicolumn{1}{|c|}{ Source } & \multicolumn{1}{c|}{ Wind Speed } \\
\hline \multirow{3}{*}{ Dugway Proving Ground } & Wind Power Class & Class $2(5.6-6.4 \mathrm{~m} / \mathrm{s}$ at $50 \mathrm{~m})$ \\
\cline { 2 - 3 } & $\begin{array}{l}\text { windNAVITGATOR tool } \\
\text { from AWS Truewind }\end{array}$ & $6.46 \mathrm{~m} / \mathrm{s}$ at $80 \mathrm{~m}, 5.93 \mathrm{~m} / \mathrm{s}$ at $50 \mathrm{~m}$ \\
\cline { 2 - 3 } & NASA SSE data & $5.17 \mathrm{~m} / \mathrm{s}$ at $50 \mathrm{~m}$ \\
\hline
\end{tabular}

To exactly determine an area's wind resource, the installation of a meteorological tower ("met tower") is required. To collect data for a commercial-scale project, using a 60-meter met tower is the current industry standard. The gathering of wind data for a minimum of one year is necessary to determine the true viability of the wind resource on-site.

\section{Siting Considerations}

The primary siting consideration for wind projects is transmission availability and the capacity of those lines. Projects need to be located within approximately 1 mile of existing transmission lines, or new lines will need to be constructed at considerable cost.

This analysis does not include any transmission costs and assumes that existing transmission lines are available to transmit power without substantial additional investment. It is also assumed that an on-site wind project would not trigger new standby or other fees from the local utility. But because wind is intermittent, the utility may have interconnection requirements to ensure grid stability and to ensure there is reliable power for the installation.

Another consideration is potential interference with airport operations. The Federal Aviation Administration (FAA) requires Notice of Proposed Construction for a project that meets certain criteria so that it can determine if there would be adverse impacts to air navigation safety. One of the triggering criteria is whether the project would be located within 20,000 feet (3.8 miles) or less of an existing public or military airport. When selecting an area for a wind project, it would be best to avoid this potential interference issue by locating the project outside of the 20,000-foot range. Any potential wind project would need to carefully 
consider this concern. An additional FAA criterion that would necessitate a Notice of Proposed Construction is any construction or alteration of more than $200 \mathrm{ft}(61 \mathrm{~m})$ in height above ground level. This criterion applies regardless of the distance from the proposed project to an airport. In response to the filing of a Notice of Proposed Construction, the FAA can either require modifications be made to the project or a "No Hazard to Air Navigation" determination can be issued and the wind project can proceed.

The FAA's Obstruction Evaluation/Airport Airspace Analysis website provides a tool to determine if the construction of a proposed structure requires FAA notification per the trigger criteria. For example, the coordinates of Latitude $40.112^{\circ}$, Longitude $-112.961^{\circ}$ in the Camel's Back Ridge and Simpson Butte area of Dugway Proving Ground were given as the location for a potential met tower and wind turbine. According to the Notice Criteria Tool on the website, this particular location also falls outside the FAA Notice Criteria zone of 20,000 feet for the on-site airfield. A 60-m met tower would not exceed the height criteria, but a wind turbine with an 80-m hub height would. Therefore, a met tower installation at this location would not require the installation to file a FAA Notice of Proposed Construction, but a commercial-scale wind energy project would.

The FAA website also provides preliminary assessment tools to determine if a proposed structure would impact long range radar, weather surveillance radar, and military operations. According to the web-based DoD Preliminary Screening Tool, a met tower or wind turbine in the example location at Dugway Proving Ground would not have any impact to Air Defense and Homeland Security long range radars or Weather Surveillance Radar-1988 Doppler (WSR-88D), but it would obviously have an impact on military operations.

The dictate of this assessment is to evaluate projects $1 \mathrm{MW}$ and larger in size. To facilitate this, the wind energy assessment is based on a one turbine project using a standard size wind turbine of 1.5 MW. Land space for more turbines may be available at the installation or a different turbine may be more suitable for a project at Dugway Proving Ground.

\section{Wind: Economic and Other Analysis Parameters}

This assessment considered the current Federal wind incentives: a 2.1\$/kWh renewable energy production tax credit (PTC) and 5-year accelerated depreciation. State-specific incentives for Utah are discussed in Appendix A.

During the original DoD renewable energy assessment in 2005, the installed cost of capital was approximately $\$ 1,400 / \mathrm{kW}$; at the current time, prices range from $\$ 1,700$ to $\$ 2,600 / \mathrm{kW}$ because of high demand and increased costs for components. The capital cost was assumed to be $\$ 2,169 / \mathrm{kW}$ (including incentives) for this economic assessment.

Dugway Proving Ground enjoys a low cost of energy. Because a wind energy project would provide intermittent power to the installation, the economics of a wind project are evaluated against the installation's direct energy charge to exclude demand and other fixed charges.

Further details on the analysis methodology and the economic and incentive parameters are documented in Appendix A, and the assumptions used are listed in Table F-3. 
Table F- 3: Performance, Cost, and Economic Characteristics

\begin{tabular}{|l|l|}
\hline Location & Dugway Proving Ground, Utah \\
\hline Conditions & $\begin{array}{l}\text { Standard: } 1.225 \mathrm{~kg} / \mathrm{m}^{3} \text { density, } \\
0^{\circ} \mathrm{F}, 0 \mathrm{~m} \text { elevation }\end{array}$ \\
\hline Assumed Average Wind Speed & $6.46 \mathrm{~m} / \mathrm{s}$ at $80 \mathrm{~m}$ \\
\hline Net Capacity Factor & $25 \%$ \\
\hline Turbine Type & $1.5 \mathrm{MW}, 77 \mathrm{~m}$ rotor, $80 \mathrm{~m}$ hub \\
\hline Project Size & 1 turbine, $1.5 \mathrm{MW}$ total \\
\hline Estimated Net Annual Energy & $3,267,132 \mathrm{kWh} / \mathrm{yr}$ \\
\hline Energy Charge & $\$ 0.026 / \mathrm{kWh}$ \\
\hline Total Capital Cost & $\$ 2,169 / \mathrm{kW}$ \\
\hline Fixed O\&M Cost & $\$ 60 / \mathrm{kW}$ \\
\hline 5-year accelerated depreciation & Included \\
\hline Federal 2.1c/kWh PTC & Included \\
\hline Sale of RECs & Included \\
\hline
\end{tabular}

\section{Findings: Wind}

The various energy cost scenarios were evaluated for ECIP eligibility and IPP project potential. To qualify for ECIP funding, a project must achieve a savings-to-investment ratio (SIR) of 1.0, and its payback is also examined. For the IPP evaluation, the commercial cost of energy was calculated to obtain an internal rate of return (IRR) of $10 \%$. This was used as the minimum IRR required to attract the interest of a wind power project developer. Table F4 lists the results of these analyses.

Table F- 4: Economic Assessment of Wind Power

\begin{tabular}{|c|c|c|c|c|}
\hline $\begin{array}{c}\text { Financing } \\
\text { Scenario }\end{array}$ & $\begin{array}{c}\text { Energy } \\
\text { Cost } \\
(\mathbf{(} / \mathbf{k W h})\end{array}$ & IRR & ECIP SIR & $\begin{array}{c}\text { Simple Payback } \\
\text { (years) }\end{array}$ \\
\hline ECIP & 2.6 & n/a & negative & 235 \\
\hline IPP & 13.9 & $10 \%$ & n/a & n/a \\
\hline
\end{tabular}

Utah has a Renewable Energy Development Incentive that provides a tax credit to eligible projects. If a wind energy project at Dugway Proving Ground is eligible for this tax incentive (eligibility is dependent on local government approval and other criteria), the cost of energy required to achieve a $10 \%$ return would be reduced by 1 cent to approximately $12.9 \mathrm{\$} / \mathrm{kWh}$. RECs would need to be sold at $10 \mathrm{\$} / \mathrm{kWh}$ to make this project cost-effective. This value is high for RECs, and it is unlikely that a buyer could be found given Utah's RPS. Lastly, a wind array could improve Dugway Proving Ground's energy security.

\section{Wind: Next Steps}

As a result of the poor wind resource and unfavorable economics, Dugway Proving Ground should not pursue a large-scale wind power project. 
Dugway's energy rates would have to drastically increase to make a wind project economically attractive given the area's marginal wind resource. Dugway Proving Ground currently enjoys low-cost power. The economic analysis of this report used the energy charge of $2.6 \$ / \mathrm{kWh}$. To reach a $10 \%$ IRR with the given wind speed, the energy rate would have to increase to $13.9 \$ / \mathrm{kWh}$. This is a large rate increase and unlikely to happen in the near future.

While a wind project at Dugway Proving Ground is not recommended and would only contribute a small amount of electricity, it could provide other benefits. Installing a wind turbine can immediately bring attention from the local community to a site's commitment to renewable energy, if for no other reason than wind energy has become synonymous with "going green." Other considerations are that the cost of wind power is not dependent upon the cost of fossil fuels, and a wind project may provide a small level of energy security.

\section{References}

AWS Truewind. 2009. “windNAVIGATOR.” http://navigator.awstruewind.com/. Accessed October 2009.

American Wind Energy Association. 2007. "Wind Power Today." http://www.awea.org/pubs/factsheets/WindPowerToday_2007.pdf. Washington D.C.

American Wind Energy Association. 2008. "Wind Power Outlook." http://www.awea.org/pubs/documents/Outlook_2008.pdf. Washington D.C.

Department of Energy and National Renewable Energy Laboratory. Utah Wind Resource Map. http://www.windpoweringamerica.gov/images/windmaps/ut_50m_800.jpg. Golden, Colorado.

Federal Aviation Administration. Obstruction Evaluation / Airport Airspace Analysis (OE/AAA). https://www.oeaaa.faa.gov/oeaaa/external/portal.jsp. Accessed September 2009.

Federal Aviation Administration. 2007. Advisory Circular (AC 70/7460-1K) Obstruction Marking and Lighting. Effective: February 2, 2007.

http://www.airweb.faa.gov/Regulatory_and_Guidance_Library/rgAdvisoryCircular.nsf/0/b99 3dcdfc37fcdc486257251005c4e21/\$FILE/AC70_7460_1K.pdf. Washington D.C.

Global Energy Concepts, LLC. 2004. “U.S. Department of Defense Renewable Energy Assessment: Report of Wind Energy Potential On and Near Military Installations.” Prepared for NREL, Golden, Colorado.

NASA Langley Research Center. 2008. “Surface meteorology and Solar Energy.” Atmospheric Science Data Center. http://eosweb.larc.nasa.gov/sse/. Accessed October 2009.

Pacific Northwest Laboratory. 1986. Wind Energy Resource Atlas of the United States. Prepared for Solar Technical Information Program \& Solar Energy Research Institute. Golden, Colorado. http://rredc.nrel.gov/wind/pubs/atlas/atlas_index.html. 
F-8

Renewable Energy Opportunities at Dugway Proving Ground, Utah Pacific Northwest National Laboratory, May 2010 


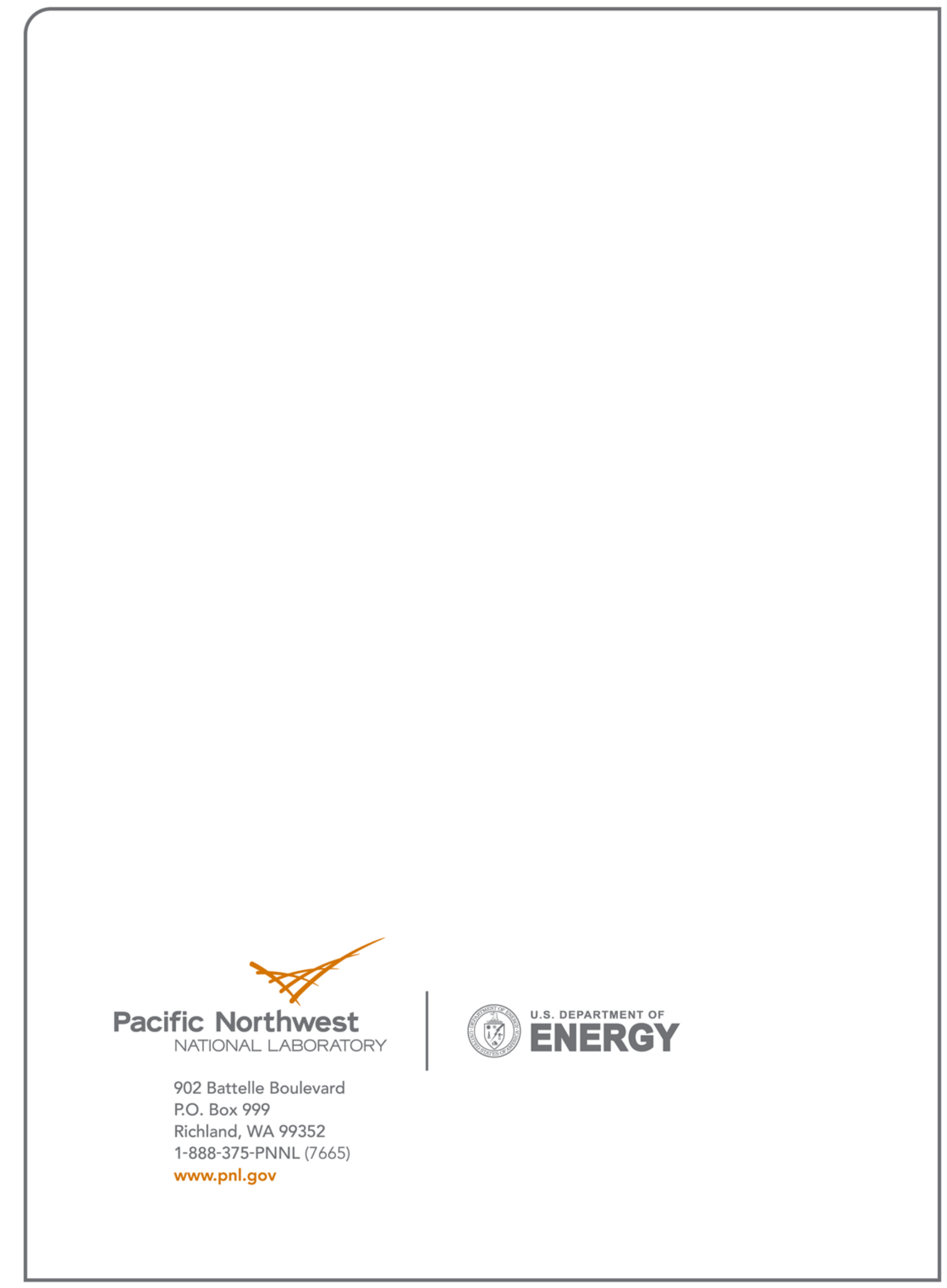

